\title{
Interventions for erosive lichen planus affecting mucosal sites (Review)
}

Cheng S, Kirtschig G, Cooper S, Thornhill M, Leonardi-Bee J, Murphy R

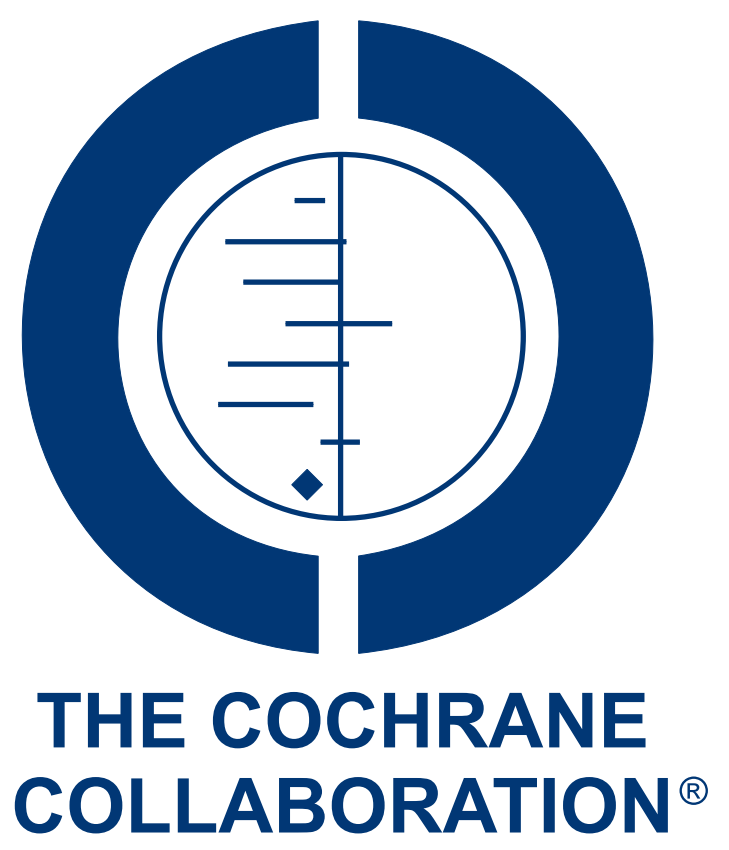

This is a reprint of a Cochrane review, prepared and maintained by The Cochrane Collaboration and published in The Cochrane Library 2012, Issue 6

http://www.thecochranelibrary.com

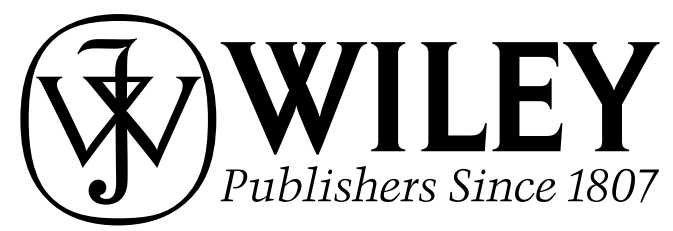

Interventions for erosive lichen planus affecting mucosal sites (Review)

Copyright $\odot 2012$ The Cochrane Collaboration. Published by John Wiley \& Sons, Ltd. 
TABLE OF CONTENTS

HEADER . . . . . . . . . . . . . . . . . . . . . . . . . . . . . . . . . . . . . . . . . . . . . . . . . . . . . .

ABSTRACT . . . . . . . . . . . . . . . . . . . . . . . . . . . . . . . . . . . . . . . . . . . . . . . . . . . . .

PLAIN LANGUAGE SUMMARY . . . . . . . . . . . . . . . . . . . . . . . . . . . . . . . . . . . . . . . . . . . .

BACKGROUND . . . . . . . . . . . . . . . . . . . . . . . . . . . . . . . . . . . . . 3

OBJECTIVES . . . . . . . . . . . . . . . . . . . . . . . . . . . . . . . . . . . . . . . . . . . . . . . . . . .

METHODS . . . . . . . . . . . . . . . . . . . . . . . . . . . . . . . . . . . . . . 5

RESUlTS . . . . . . . . . . . . . . . . . . . . . . . . . . . . . . . . . . . . . . . . . . . .

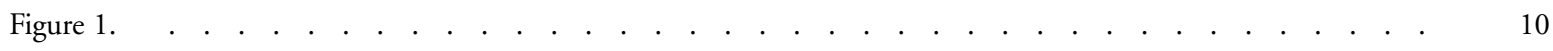

Figure 2.

DISCUSSION . . . . . . . . . . . . . . . . . . . . . . . . . . . . . . . . . . . . .

AUTHORS' CONCLUSIONS . . . . . . . . . . . . . . . . . . . . . . . . . . . . . . . . . . . . . . . 16

ACKNOWLEDGEMENTS . . . . . . . . . . . . . . . . . . . . . . . . . . . . . . . . . . . . . .

REFERENCES . . . . . . . . . . . . . . . . . . . . . . . . . . . . . . . . . . . . . . 16

CHARACTERISTICS OF STUDIES . . . . . . . . . . . . . . . . . . . . . . . . . . . . . . . . . . . . . . . . . .

DATA AND ANALYSES . . . . . . . . . . . . . . . . . . . . . . . . . . . . . . . . . . . . . . . . . . . . . .

Analysis 1.1. Comparison 1 Pimecrolimus versus placebo/vehicle cream, Outcome 1 Pain reduction using visual analogue scale (VAS). . . . . . . . . . . . . . . . . . . . . . . . . . . . . . . . . . . 54

Analysis 1.2. Comparison 1 Pimecrolimus versus placebo/vehicle cream, Outcome 2 Physician Global Assessment: Weighted sums of ulceration, erythema and reticulation $\left(\mathrm{mm}^{2}\right) . \quad$. . . . . . . . . . . . . . . . . . . . 55

Analysis 1.3. Comparison 1 Pimecrolimus versus placebo/vehicle cream, Outcome 3 Physician Global Assessment: Surface of erosive lesions.

Analysis 1.4. Comparison 1 Pimecrolimus versus placebo/vehicle cream, Outcome 4 Physician Global Assessment. $\quad . \quad 56$

Analysis 1.5. Comparison 1 Pimecrolimus versus placebo/vehicle cream, Outcome 5 Clinical response: Complete clearance.

Analysis 2.1. Comparison 2 Clobetasol propionate versus active treatment, Outcome 1 Pain reduction using visual analogue scale (VAS).

Analysis 2.2. Comparison 2 Clobetasol propionate versus active treatment, Outcome 2 Improvement in pain symptoms by VAS $(>=50 \%)$.

Analysis 2.3. Comparison 2 Clobetasol propionate versus active treatment, Outcome 3 Physician Global Assessment (Thongprasom score).

Analysis 2.4. Comparison 2 Clobetasol propionate versus active treatment, Outcome 4 Physician Global Assessment (Thongprasom score)

Analysis 3.1. Comparison 3 0.1\% Triamcinolone acetonide versus ciclosporin, Outcome 1 Pain reduction using visual analogue scale (VAS) (0 to 100 scale).

Analysis 3.2. Comparison 3 0.1\% Triamcinolone acetonide versus ciclosporin, Outcome 2 Physician Global Assessment (Thongprasom score).

Analysis 4.1. Comparison 4 0.1\% Tacrolimus versus $0.05 \%$ clobetasol, Outcome 1 Pain reduction using the VAS (0 to 10 score).

Analysis 5.1. Comparison 5 Aloe vera gel versus placebo, Outcome 1 Improvement in pain symptoms by VAS $(>=50 \%)$ (Complete or good response versus poor or no response).

Analysis 5.2. Comparison 5 Aloe vera gel versus placebo, Outcome 2 Physician Global Assessment (Thongprasom score).

Analysis 6.1. Comparison 6 Ciclosporin versus active treatment, Outcome 1 Improvement in pain symptoms by VAS (> = $50 \%$ ) (no symptoms versus partial or no response).

Analysis 6.2. Comparison 6 Ciclosporin versus active treatment, Outcome 2 Physician Global Assessment (Thongprasom score).

Analysis 6.3. Comparison 6 Ciclosporin versus active treatment, Outcome 3 Physician Global Assessment: Severity of disease.

Analysis 7.1. Comparison 7 Radix tripterygium hypoglaucum (THT) vs tripterygium glucosides (TGT), Outcome 1 Physician Global Assessment: Cure of erosive lesions.

Analysis 8.1. Comparison 8 Flucinonide vs placebo, Outcome 1 Physician Global Assessment: Clinical signs (Complete vs good, partial, or no response). 
Analysis 9.1. Comparison 9 Betamethasone versus 0.1\% triamcinolone acetonide, Outcome 1 Physician Global Assessment: Clinical severity (0 to 12 score).

ADDITIONAL TABLES . . . . . . . . . . . . . . . . . . . . . . . . . . . . . . . . . . . . . . . . 64

APPENDICES . . . . . . . . . . . . . . . . . . . . . . . . . . . . . . . . . . . . . . . . 70

WHAT'S NEW .. . . . . . . . . . . . . . . . . . . . . . . . . . . . . . . . . . . . . 72

CONTRIBUTIONS OF AUTHORS . . . . . . . . . . . . . . . . . . . . . . . . . . . . . . . . . . . . . . . 72

DECLARATIONS OF INTEREST . . . . . . . . . . . . . . . . . . . . . . . . . . . . . . . . . . . . . . 73

SOURCES OF SUPPORT . . . . . . . . . . . . . . . . . . . . . . . . . . . . . . . . . . . 73

DIFFERENCES BETWEEN PROTOCOL AND REVIEW . . . . . . . . . . . . . . . . . . . . . . . . . . . . 73

INDEX TERMS . . . . . . . . . . . . . . . . . . . . . . . . . . . . . . . . . . . . . . . . . . . . . . . . . . 


\title{
[Intervention Review]
}

\section{Interventions for erosive lichen planus affecting mucosal sites}

\author{
Suzanne Cheng ${ }^{1}$, Gudula Kirtschig ${ }^{2}$, Susan Cooper $^{3}$, Martin Thornhill ${ }^{4}$, Jo Leonardi-Bee ${ }^{5}$, Ruth Murphy ${ }^{1}$ \\ ${ }^{1}$ Department of Dermatology, Queen's Medical Centre, Nottingham, UK. ${ }^{2}$ Department of Dermatology, VU University Medical \\ Center, Amsterdam, Netherlands. ${ }^{3}$ Department of Dermatology, Churchill Hospital, Oxford, UK. ${ }^{4}$ Clinical Academic Unit of Oral \\ and Maxillofacial Medicine and Surgery, University of Sheffield School of Clinical Dentistry, Sheffield, UK. ${ }^{5}$ Division of Epidemiology \\ and Public Health, The University of Nottingham, Nottingham, UK
}

Contact address: Ruth Murphy, Department of Dermatology, Queen's Medical Centre, Nottingham, NG7 2UH, UK. ruthmurphy1@aol.com.

Editorial group: Cochrane Skin Group.

Publication status and date: Edited (no change to conclusions), published in Issue 6, 2012.

Review content assessed as up-to-date: 15 June 2009.

Citation: Cheng S, Kirtschig G, Cooper S, Thornhill M, Leonardi-Bee J, Murphy R. Interventions for erosive lichen planus affecting mucosal sites. Cochrane Database of Systematic Reviews 2012, Issue 2. Art. No.: CD008092. DOI: 10.1002/14651858.CD008092.pub2.

Copyright (C) 2012 The Cochrane Collaboration. Published by John Wiley \& Sons, Ltd.

\begin{abstract}
A B S T R A C T
Background

Erosive lichen planus (ELP) affecting mucosal surfaces is a chronic autoimmune disease of unknown aetiology. It is often more painful and debilitating than the non-erosive types of lichen planus. Treatment of erosive lichen planus is difficult and aimed at palliation rather than cure. Several topical and systemic agents have been used with varying results. Another Cochrane review has already assessed interventions for lichen planus affecting the mouth.
\end{abstract}

\section{Objectives}

To assess the effects of interventions in the treatment of erosive lichen planus affecting the oral, anogenital, and oesophageal regions.

\section{Search methods}

We searched the following databases up to September 2009: the Cochrane Skin Group Specialised Register, the Cochrane Central Register of Controlled Trials (CENTRAL) in The Cochrane Library, MEDLINE (from 2005), EMBASE (from 2007), and LILACS (from 1982). We also searched reference lists of articles and online trials registries for ongoing trials.

\section{Selection criteria}

We considered all randomised controlled trials (RCTs) that evaluated the effectiveness of any topical or systemic interventions for ELP affecting either the mouth, genital region, or both areas, in participants of any age, gender, or race.

\section{Data collection and analysis}

The primary outcome measures were as follows:

(a) Pain reduction using a visual analogue scale rated by participants;

(b) Physician Global Assessment; and

(c) Participant global self-assessment.

Changes in scores at the end of therapy compared with baseline were analysed.

Interventions for erosive lichen planus affecting mucosal sites (Review)

Copyright ( 2012 The Cochrane Collaboration. Published by John Wiley \& Sons, Ltd. 


\section{Main results}

Fifteen RCTs were included, giving a total of 473 participants with ELP (study sizes ranged between 8-94). All studies involved oral sites only. Six studies included participants with non-erosive lichen planus but only the erosive subgroup was included for intended subgroup analysis. We were unable to pool data from any of the nine studies with only ELP participants or any of the six studies with the ELP subgroup, due to small numbers and the heterogeneity of the interventions, design methods, and outcome variables between studies.

One study involving 50 participants found that $0.025 \%$ clobetasol propionate administered as liquid microspheres significantly reduced pain compared to ointment (Mean difference (MD) -18.30, 95\% confidence interval (CI) -28.57 to -8.03), but outcome data was only available in 45 participants (high risk of performance bias for blinding of participants, low/unclear risk of bias overall). However, in another study, a significant difference in pain was seen in the small subgroup of 11 ELP participants, favouring ciclosporin solution over $0.1 \%$ triamcinolone acetonide in orabase (MD - $1.40,95 \%$ CI - 1.86 to - 0.94 ) (high risk of performance and detection bias due to likely lack of blinding, low/unclear risk of bias overall). Aloe vera gel was 6 times more likely to result in at least a 50\% improvement in pain symptoms compared to placebo in a study involving 45 ELP participants (Risk ratio (RR) 6.16, 95\% CI 2.35 to 16.13) (low risk of bias overall). No significant difference was seen in Physician Global Assessment in these three studies.

In a small single study involving 20 ELP participants, $1 \%$ pimecrolimus cream was 7 times more likely to result in a strong improvement as rated by the Physician Global Assessment when compared to vehicle cream (RR 7.00, 95\% CI 1.04 to 46.95) (low risk of bias overall). In a study involving a small subgroup of 8 ELP participants, a significant difference was seen for an improvement in the severity of the disease as rated by the Physician Global Assessment, in favour of the ciclosporin group when compared to the vehicle (MD -1.40, $95 \%$ CI -1.86 to -0.94) (unclear risk of selection bias for allocation concealment, overall risk of bias low).

No statistically significant benefits were shown for topical tacrolimus or fluticasone spray in two separate studies of 29 and 44 participants respectively.

There is no overwhelming evidence for the efficacy of a single treatment, including topical steroids, which are the widely accepted firstline therapy for ELP. Several side-effects were reported, but none were serious. With topical corticosteroids, the main side-effects were oral candidiasis and dyspepsia.

\section{Authors' conclusions}

This review suggests that there is only weak evidence for the effectiveness of any of the treatments for oral ELP, whilst no evidence was found for genital ELP. More RCTs on a larger scale are needed in the oral and genital ELP populations. We suggest that future studies should have standardised outcome variables that are clinically important to affected individuals. We recommend the measurement of a clinical severity score and a participant-rated symptom score using agreed and validated severity scoring tools. We also recommend the development of a validated combined severity scoring tool for both oral and genital populations.

\section{PLAIN LANGUAGE SUMMARY}

\section{Treatments for erosive lichen planus affecting mucosal sites}

Erosive lichen planus (ELP) is a condition that affects the mouth, oesophagus (food pipe or gullet), and anogenital region. It is caused by an over-active immune system. It is often more painful and debilitating than the non-erosive types of lichen planus. Depending on the site involved, affected individuals may experience pain, and difficulty eating; passing urine; or having sexual intercourse. Treatment is difficult and aimed at controlling symptoms, rather than cure. Several creams and tablets have been used with varying results.

This review looked at the effectiveness of treatments for ELP and included 15 studies, with 473 participants with ELP. All involved oral, but not genital, disease. Many studies were excluded either because they were not randomised controlled trials (where participants are divided into two groups at random) or because they recruited participants with all types of lichen planus, rather than just the erosive subtypes. All of these studies recruited small numbers of participants (12 to 94) and used a variety of different assessment methods and timings; hence, it was not possible to combine or compare results between studies directly.

We found only weak evidence for the effectiveness of any of the treatments for oral ELP. None of the studies involved genital or oesophageal disease; hence, no evidence was found for the treatment of these conditions. One small study found that $0.025 \%$ clobetasol propionate (a very potent topical steroid) administered as a spray significantly reduced pain when compared to ointment. In another study, a significant difference in pain was seen in the small subgroup of $11 \mathrm{ELP}$ participants, favouring ciclosporin solution over $0.1 \%$ 
triamcinolone acetonide in orabase (a potent topical steroid). In a study involving 45 ELP participants, aloe vera gel was 6 times more likely to result in at least a 50\% improvement in pain symptoms compared to placebo. In a study involving a small subgroup of 8 ELP participants, a significant difference was seen for an improvement in the severity of the disease in favour of the ciclosporin group when compared to the vehicle.

Several side-effects were reported, but none were serious. With topical corticosteroids, the main side-effects were oral candida (yeast) infection and pain or discomfort in the upper abdomen. Temporary burning was a common side-effect reported with tacrolimus $0.1 \%$ ointment and pimecrolimus $0.1 \%$ cream.

Overall, there was no overwhelming evidence for the effectiveness of any single treatment, including topical steroids, which are the widely accepted first-line therapy for ELP. This was mainly due to the lack of good-quality, well-conducted trials and small participant numbers. Another Cochrane review has already assessed interventions for lichen planus affecting the mouth.

\section{B A C K G R O U N D}

\section{Description of the condition}

\section{Definition}

Lichen planus (LP) is an inflammatory condition that affects the skin and the squamous epithelium of mucosal surfaces lining the mouth, ears, eyes, and nose as well as the gastrointestinal and anogenital tracts. There are predominantly two patterns of inflammation described: the plaque (raised) type and the erosive (raw) type, although bullous, blistering, or hypertrophic (thickened) types also occasionally occur.

The plaque type occurs most commonly and is estimated to affect up to $2 \%$ of the population (Boyd 1991; Carrozzo 2008). It presents as purple raised areas with a surface made of a lacy, white network known as Wickham's striae. The lesions are predominantly distributed on the inner aspect of the wrists and ankles, although they may occur on any body surface lined with squamous epithelium (Boyd 1991; Breathnach 2004). Plaques of LP are often itchy, and, without treatment, they may take up to two years to settle. Occasionally the lesions are present without many symptoms and may remain for years (Boyd 1991; Breathnach 2004). In contrast, erosive lichen planus (ELP) is a very painful and debilitating condition. The prevalence of ELP is unknown. It occurs predominantly, but not exclusively, on the mucosal surfaces of the mouth and genitals (oral, vulval, vaginal, and penile lichen planus). Other less commonly affected sites include the eyes (Neumann 1993) and oesophagus (Abraham 2000). There may also be bladder, nasal, laryngeal, gastric, and anal involvement (Eisen 1999). Erosive lichen planus can be accompanied by classical cutaneous LP or other forms of mucosal LP, namely reticular (lacy), papular (solid, raised bumps less than $5 \mathrm{~mm}$ in diameter), plaque (raised), atrophic (thinned), and bullous (blisters) variants.
A severe variant of ELP in women involving both the genital and oral mucosa was described by Pelisse et al (Pelisse 1982; Pelisse 1989 ) as the vulvovaginal-gingival (VVG) syndrome. This syndrome is a triad of (erosive or desquamative) vulvitis, vaginitis, and gingivitis. The equivalent condition in men is known as the peno-gingival (PG) syndrome, described by Cribier et al in 1993 (Cribier 1993).

Since ELP can affect different body sites, a number of healthcare specialists are involved in managing affected individuals: oral medicine physicians; dermatologists; gynaecologists; and, if the oesophagus is involved, gastroenterologists.

\section{Impact of Erosive Lichen Planus}

Erosive lichen planus is a chronic, painful condition, which is often difficult to treat. The psychological, emotional, and physical distress associated with ELP affecting any mucosal site can be significant with affected individuals suffering low moods with or without treatment. This has economic consequences both for the people affected and the health system. Affected individuals frequently attend hospital complaining of pain and loss of function, which interferes with their personal and working life. It is important that healthcare providers are able to identify and treat any psychological issues arising as a result of ELP. Engaging a counsellor, as part of the multidisciplinary team, may be beneficial in these instances.

Symptoms vary according to the site involved. Individuals with erosive oral lichen planus (OLP) present with pain and difficulty eating. With milder disease the discomfort is mainly from spicy or acidic foods, and fizzy drinks. With more extensive disease there are painful, persistent erosions on the gingivae (gums), and ulcers on the buccal (inside of cheek), tongue, and labial (lip) mucosae. Difficulty eating results in weight loss and nutritional deficiencies, such as iron deficiency (Eisen 1999). Painful erosions lead to suboptimal dental hygiene and increased tooth decay. 
The areas commonly affected in the vulva are the labia minora (inner lips), introitus (entrance to the vagina), and vaginal vault (arched roof of the vaginal cavity). The affected areas may be erythematous, atrophic, and eroded. This makes them tender and extremely painful to light touch, such as pressure from sitting and walking. Individuals complain of pain and stinging on passing urine, and they are sometimes only able to urinate in comfort by sitting or standing in water in the bath or shower. Anatomical alterations, such as fusion of the labia minora, may cause impaired urine flow.

Sexual intercourse can be impossible due to pain and anatomical changes. In addition, the eroded vagina bleeds easily on contact; hence, postcoital bleeding (bleeding following sexual intercourse) is typical. Inflammation higher up in the vagina (desquamative vaginitis) presents as a yellow discharge. With ongoing inflammation, the clitoral hood typically disappears, the labia minora adheres to the labia majora, and the introitus closes over. Scarring in the vagina leads to narrowing and a fibrosed vaginal vault, making cervical smears either impossible or difficult. In addition to organic dysfunction, the architectural disfigurement will cause psychological distress.

In men, ELP characteristically affects the glans penis, producing similar painful, tender, red and raw lesions, and reduced sexual function.

\section{Risk of Malignant Transformation}

Lesions of LP are thought to have an increased risk of development of malignancies; therefore, it is mandatory to follow up these people. The World Health Organization (WHO) criteria (Kramer 1978) states that oral LP is a condition that predisposes to malignant transformation. Approximately $1 \%$ to $5 \%$ of oral LP lesions will undergo malignant changes into squamous cell carcinoma (SCC) of the mouth (Gandolfo 2004; Holmstrup 1988; Lo Muzio 1998; Silverman 1985). Approximately $1 \%$ to $3 \%$ of vulval LP lesions develop into SCC (Cooper 2006; Lewis 1994) and a small, but unknown, percentage of penile LP lesions transform into SCC (Bain 1989; Leal-Khouri 1994). High-risk factors for malignant transformation in oral LP include smoking; excessive alcohol ingestion; erosive or atrophic clinical types; presence of erythroplakic lesions (reddened patches with a velvety surface found in the mouth); and sites involving the tongue, gingival, or buccal mucosa (Scully 2008). No risk factors are known for progression of vulval LP into carcinoma of the vulva. It is unknown if early treatment of ELP reduces the risk of malignancy.

\section{Description of the intervention}

The management of ELP is challenging, and there is no clear agreement with respect to the best first-line treatment in oral or genital disease. Indeed, neither is there agreement as to whether first-line therapy should be the same at both sites. People often respond poorly to the available treatments. The treatments for both oral and genital ELP are similar, but they have never previously been considered together in a systematic review. Clinical experience of combined oral medicine and dermatology clinics suggests that effective treatment for ELP in the oral region is likely to be beneficial in the genital region and vice versa. ELP is a chronic autoimmune condition with T-cell mediated immunity playing a major role; hence, most interventions are targeted at the immune system and increasingly at treatments to reduce T-cell activity.

Most clinicians use topical or intralesional steroids as first-line treatment for both oral and genital ELP. There is no clinical agreement for second-line therapy, although a short course of systemic steroids may be administered for rapid control of symptoms. Steroid-sparing agents, such as azathioprine, methotrexate (Jang 2008), or ciclosporin, can be used. Topical or systemic retinoids, anti-malarials, dapsone, psoralen + UVA treatment (PUVA) (Lundquist 1995), thalidomide (Camisa 2000), aloe vera gel (Rajar 2008), topical tacrolimus (Kaliakatsou 2002), or topical rapamycin (Soria 2009) may be considered in refractory cases. Surgical management, such as carbon dioxide laser, cryotherapy, and excision, is not recommended due to the possibility of triggering lesions (Koebner's phenomenon) and recurrence of the inflammatory condition.

In recent years, reports have been published on the use of biological therapies, such as efalizumab (Cheng 2006; Heffernan 2007) and alefacept (Chang 2008). However, the European Medicines Agency (EMEA), which is the European Union (EU) body responsible for monitoring the safety of medicines, has recommended the suspension of marketing authorisation for efalizumab (Raptiva) over possible links between the drug and progressive multifocal leukencephalopathy (PML). A recent small case series comparing alefacept to placebo reported that alefacept may confer a moderate therapeutic response in ELP (Chang 2008). Alefacept is approved by the US Food and Drugs Administration (FDA) for the treatment of psoriasis, but it is not approved in the UK.

\section{How the intervention might work}

The exact cause of ELP is poorly understood. It is thought to be autoimmune and idiopathic in most cases. Studies suggest that upregulation of T-cell-mediated immunity plays a major role (Baldo 2010; Boyd 1991; Porter 1997; Scully 2008; Thornhill 2001), resulting in apoptosis of epithelial cells and chronic inflammation. Most interventions that are reported to improve ELP, as described above, have immunomodulatory or immunosuppressive effects. This may explain why efalizumab has been beneficial in some cases (Cheng 2006; Heffernan 2007).

\section{Why it is important to do this review}


For years, the accepted first-line therapy for ELP has been the use of ultra-potent topical steroids (Carbone 2009). Whilst there appears to be symptomatic improvement for some people (Cooper 2006), the condition rarely goes into complete remission. In addition to assessing whether treatments can improve symptoms in the short-term, it is important to assess the long-term management of ELP. This is because it is a chronic condition and long-term use of some treatments, like potent topical steroids, can have sideeffects, such as skin thinning. There is poor consensus for a secondline therapy in individuals who have failed to adequately respond to topical steroids. This has resulted in the emergence of newer therapies, such as tacrolimus (Lozada-Nur 2006) and efalizumab (Heffernan 2007), in recent years. In such a painful and disabling condition, it is important that affected individuals are given the most therapeutically efficacious treatments.

A Cochrane review update on 'Interventions for oral lichen planus' has recently been published (Thongprasom 2011). The authors identified 28 randomised controlled trials (RCTs); however, due to the wide range of interventions compared, there is insufficient evidence to support the effectiveness of any specific treatment for oral LP as being superior. Another systematic review focusing on treatments used in oral LP (Zakrzewska 2005) concluded that due to small study sizes, lack of standardised outcome measures, and high likelihood of publication bias, the results are not reliable. Our review is different to these because it is not restricted to oral disease and focuses only on the erosive type of LP. Because ELP is a systemic disease affecting all mucosal surfaces, this review looks at not only oral sites, but all mucosal sites. Individuals with ELP affecting multiple mucosal sites represent a particularly challenging subset of individuals to treat.

\section{O B JECT IVES}

To assess the effects of interventions in the treatment of erosive lichen planus affecting the oral, anogenital, and oesophageal regions.

\section{METHODS}

\section{Criteria for considering studies for this review}

\section{Types of studies}

We considered all randomised controlled trials (RCTs) that evaluated the effectiveness of either topical or systemic interventions for ELP affecting either the mouth, genital region, or both areas. We included cross-over studies, but not split body-part designs because it is not possible to apply two topical treatments to either half of the oral mucosa or vulva without cross-contamination.

\section{Types of participants}

We included any individual of any age, gender, or race who had been diagnosed by either a dermatologist, oral medicine physician, genitourinary physician, or a gynaecologist as having ELP affecting the mouth, oesophagus, and/or anogenital regions. A clinical diagnosis stating specifically 'erosive lichen planus' alone from an experienced physician was considered diagnostically sufficient. A histological diagnosis was not considered necessary since for erosive disease there are no specific histological features. Biopsy often serves to exclude dysplasia, rather than confirm the diagnosis of ELP.

We excluded any studies including individuals with idiopathic, plaque-like LP (non-erosive); individuals with lichenoid drug eruptions; or individuals showing evidence of dysplasia.

\section{Types of interventions}

We included all types of interventions, including topical treatments (such as potent topical steroids, ciclosporin, tacrolimus, and retinoids), oral medications (such as prednisolone, azathioprine, methotrexate, retinoids, ciclosporin, and mycophenolate), antimalarials, biologics, phototherapy, and surgical management.

We also included trials of different doses of the same intervention, comparison trials between different interventions, intervention versus placebo trials, intervention versus 'no treatment' trials, and cross-over studies. We also explored intervention strategies, such as intermittent therapies that are designed to maintain remission and prevent further flares.

\section{Types of outcome measures}

Most outcome measures in ELP are assessed clinically. This includes a scale-rating of improvement of clinical signs (e.g. erythema, ulceration) by investigators and symptoms (e.g. pain, discomfort) by participants as well as restoration of normal functions, such as sexual activity and a varied diet (ability to eat), as reported by participants.

\section{Primary outcomes}

(a) Pain reduction using a visual analogue scale rated by participants (e.g. 0 to 10).

(b) Physician Global Assessment (e.g. five-point).

(c) Participant global self-assessment. 


\section{Secondary outcomes}

(a) Complete clinical response defined as the percentage of participants with complete resolution of clinical signs or symptoms.

(b) Partial response defined as the percentage of participants with at least $50 \%$ improvement.

A partial clinical response was defined as at least $50 \%$ improvement, mainly to test the literature. In practice, affected individuals would usually report that they are "better", "worse", or "the same".

(c) Reduction in severity of flares.

(d) Reduction in number of flares.

(e) Relapse rate when medications are stopped or reduced.

(f) Dermatology quality of life measures.

(g) Restoration of sexual activity (of most relevance to genital sites).

(h) Eating a normally varied diet (most relevant to oral involvement).

(i) Side-effects reported.

(j) Reduction in target/mean lesion size (for oral lesions).

\section{Timing of outcome assessment}

Where possible, we recorded outcomes in the short-term (less than six months) and long-term (six months or more) from the beginning of treatment.

\section{Search methods for identification of studies}

We aimed to identify all relevant randomised controlled trials (RCTs) regardless of language or publication status (published, unpublished, in press, and in progress).

\section{Electronic searches}

We searched the following databases up to 7 September 2009:

- the Cochrane Skin Group Specialised Register using the following search terms: ((eros* or vulva* or oral or ulcerated or mucos*) and (lichen and planus)) or (lichen and planus);

- the Cochrane Central Register of Controlled Trials

(CENTRAL) in The Cochrane Library using the search strategy in Appendix 1;

- MEDLINE (from 2005) using the search strategy in Appendix 2;

- EMBASE (from 2007) using the search strategy in

Appendix 3; and

- LILACS (Latin American and Caribbean Health Science Information database, from 1982) using the search strategy in Appendix 4.

The UK and US Cochrane Centres (CCs) have an ongoing project to systematically search MEDLINE and EMBASE for reports of trials that are then included in the Cochrane Register of Controlled Trials. Searches have been undertaken for this review by the Cochrane Skin Group to cover the years that have not been searched by the UK and US CCs.

A final prepublication search for this review was undertaken on 17 August 2011. Although it has not been possible to incorporate RCTs identified through this search within this review, relevant references are listed under Studies awaiting classification. They will be incorporated into the next update of the review.

\section{Ongoing trials}

We searched for ongoing trials in the following registers using the term 'erosive lichen planus' on 26 June 2011:

- The metaRegister of Controlled Trials (www.controlledtrials.com).

- The US National Institutes of Health Ongoing Trials Register (www.clinicaltrials.gov).

- The Australian New Zealand Clinical Trials Registry ( www.anzctr.org.au).

- The World Health Organization International Clinical Trials Registry platform (www.who.int/trialsearch).

- The Ongoing Skin Trials Register (www.nottingham.ac.uk/ ongoingskintrials).

\section{Searching other resources}

\section{Unpublished and Grey literature}

We attempted to obtain unpublished trials through correspondence with authors.

\section{Reference lists}

We examined reference lists of the relevant trials and reviews identified.

\section{Correspondence}

We wrote to trial authors to clarify trial details.

\section{Language}

We did not impose language restrictions when searching for trials, and we sought translations where necessary.

\section{Adverse Effects}

We searched the included studies for reports of adverse effects. 


\section{Data collection and analysis}

\section{Selection of studies}

Two authors (SCh and RM) independently reviewed the titles, abstracts, and key words of all records retrieved in the searches. SCh and RM obtained the full text of all relevant, or possibly relevant, references.

\section{Data extraction and management}

We designed a paper data extraction form according to the predefined selection criteria. Two authors (SCh and RM) independently confirmed eligibility, assessed quality, and extracted data. Differences in opinion were resolved by discussion with a third author until a consensus was met. We kept logs of excluded studies with reasons for exclusion. One author (JL-B) checked and entered data into Review Manager.

\section{Assessment of risk of bias in included studies}

Two authors (SCh and RM) independently assessed the quality of the included studies by using the new features of Review Manager, as described in Table 8.5c of the Cochrane Handbook for Systematic Reviews of Interventions (Higgins 2011), to assess the risk of bias (selection bias, performance bias, attrition bias, and detection bias).

\section{Measures of treatment effect}

We presented binary data as risk ratios (RR) with $95 \%$ confidence intervals (CI). We presented continuous data as mean differences (MD) with 95\% CIs.

\section{Unit of analysis issues}

There were no unit of analysis issues since all studies randomised whole participants. For studies that used a cross-over trial design, we presented the results based on those reported in the original paper since we were unable to estimate appropriate statistics that allowed for the design (for example, conditional odds ratios).

\section{Dealing with missing data}

We contacted the trial authors to try to obtain trial-level data not originally reported, and we received replies from two authors. As we did not expect to have access to individual participant-level data, we did not perform any imputation procedures.

\section{Assessment of heterogeneity}

We planned to quantify statistical heterogeneity using $\mathrm{I}^{2}$ statistic; however, no pooling of studies was performed due to the limited numbers of studies and clinical heterogeneity between the trials.

\section{Assessment of reporting biases}

We planned to generate a funnel plot to assess publication bias; however, this was not possible due to insufficient studies.

\section{Data synthesis}

Due to the limited number of studies and heterogeneity of interventions, we were unable to perform meta-analyses but, where possible, we have presented the results from individual studies using forest plots.

\section{Subgroup analysis and investigation of heterogeneity}

We planned to perform subgroup analysis to explore treatment effect differences between ELP of the mouth and genitals; however, we were unable to do this since we did not identify any eligible studies of genital ELP.

\section{RES U L T S}

\section{Description of studies}

See: Characteristics of included studies; Characteristics of excluded studies; Characteristics of studies awaiting classification; Characteristics of ongoing studies.

Please see Table 1 ('Summary of Included Studies') for a simple summary of the data in the 'Characteristics of included studies' tables.

\section{Results of the search}

The database search identified 220 papers initially. Fifty-one full text papers were retrieved, of which 15 were included (Campisi 2004; Carbone 2009; Choonhakarn 2008; Conrotto 2006; Eisen 1990; Hegarty 2002; Lin 2005; Malhotra 2008; Passeron 2007; Radfar 2008; Sardella 1998; Swift 2005; Volz 2008; Voute 1993; Yoke 2006). 


\section{Included studies}

The 15 included RCTs had a total of 667 participants with LP affecting mucosal sites, of which 473 participants had the erosive subtype of LP. Please see the 'Characteristics of included studies' tables for detailed information about all of the included studies, which are summarised as follows.

\section{Design}

Fourteen studies were conducted as a parallel design, and 1 study was conducted as a cross-over design (Hegarty 2002).

\section{Sample sizes}

The number of participants in each individual study ranged from 12 to 139 . Table 1 summarises the range of therapies. All of the included studies recruited participants with only oral - not genital - disease. Six studies (Choonhakarn 2008; Eisen 1990; Malhotra 2008; Sardella 1998; Voute 1993; Yoke 2006) included participants with non-erosive LP. The breakdown of data on the ELP subset was, either, already published or obtained directly from the authors on request; hence, these studies were included, but considered separately. This brings the total number of participants with ELP to 473 (individual studies ranged between 8 to 94 participants).

\section{Setting}

All included studies were performed in secondary care. One study (Yoke 2006) was a multicentre study.

\section{Participants}

The diagnosis of ELP was confirmed clinically in all studies and histologically in all but one (Malhotra 2008). Three studies (Carbone 2009; Conrotto 2006; Sardella 1998) were based on the WHO 1978 criteria for oral precancerous lesions (Kramer 1978).

\section{Interventions}

Multiple therapies were considered, as shown in Table 1.

Six studies compared an active topical agent (aloe vera gel, ciclosporin rinse, fluocinonide in adhesive base, and 1\% pimecrolimus cream in three studies) to placebo.

Two studies compared topical clobetasol propionate, currently the most frequently used treatment in clinical practice, either in a different delivery vehicle (lipid-loaded microspheres versus ointment) or a different concentration $(0.025 \%$ versus $0.05 \%)$.

Seven studies compared an active agent against another active agent head-to-head. These therapies can be broadly divided into three groups: (i) topical steroids - clobetasol propionate ointment and gel, triamcinolone acetonide paste, fluticasone propionate spray, betamethasone sodium phosphate mouthwash;

(ii) other topical therapy - tacrolimus ointment, ciclosporin gel and solution, mesalazine gel; or

(iii) systemic therapy - betamethasone oral mini-pulse therapy, root of (radix) tripterygium hypoglaucum tablet (THT), tripterygium glucosides tablet (TGT).

\section{Outcomes}

\section{Primary outcomes}

There was no consensus in the included studies regarding the tools used for assessing the primary outcomes (see Table 2).

\section{(a) Pain reduction using a visual analogue scale rated by participants}

Ten studies measured participant-reported symptoms using a visual analogue scale of 0 to 10 or 0 to 100 (Campisi 2004; Carbone 2009; Choonhakarn 2008; Conrotto 2006; Hegarty 2002; Radfar 2008; Sardella 1998; Swift 2005; Volz 2008; Yoke 2006). Voute 1993 also measured using a visual analogue scale (VAS), but the scale was not specified. Two studies measured this using different tools: Passeron 2007 used a visual scale of 0 to 4, and Eisen 1990 measured global symptom scores on an ordinal scale of 0 to 3 . Two studies (Lin 2005; Malhotra 2008) did not measure participantreported symptoms at all.

\section{(b) Physician Global Assessment (e.g. five-point)}

All but 2 studies (Radfar 2008; Sardella 1998) measured physician global assessment, but using several different methods: 6 studies (Campisi 2004; Carbone 2009; Choonhakarn 2008; Conrotto 2006; Hegarty 2002; Yoke 2006) used the clinical grading by Thongprasom 1992 consisting of a 6-point ordinal scale from 0 (no lesions) to 5 (white striae with erosive area more than $1 \mathrm{~cm}^{2}$ ), 6 used their own clinical grading scale (Eisen 1990; Lin 2005; Malhotra 2008; Passeron 2007; Volz 2008; Voute 1993), whilst Swift 2005 measured clinical score as weighted sums of ulceration $\mathrm{mm}^{2}$, erythema $\mathrm{mm}^{2}$, and reticulation $\mathrm{mm}^{2}$.

\section{(c) Participant global self-assessment}

One study asked participants about their subjective evaluation of the efficacy of treatment at the end of the study (Passeron 2007) on a five-point ordinal scale (worse, no effect, mild, moderate, or important improvement). 


\section{Secondary outcomes}

The majority of the secondary outcomes specified in this review were not assessed in the included studies: e.g. (c) Reduction in severity of flares, $(d)$ Reduction in number of flares, $(g)$ Restoration of sexual activity (of most relevance to genital sites), and (b) Eating a normally varied diet (most relevant to oral involvement).

(a) Complete clinical response defined as the percentage of participants with complete resolution of clinical signs or symptoms

Volz 2008 reported complete clinical response.

\section{(b) Partial response defined as the percentage of participants with at least $50 \%$ improvement}

A partial clinical response was defined as at least $50 \%$ improvement, mainly to test the literature. In practice, affected individuals would usually report that they were 'better', 'worse', or 'the same'. Carbone 2009, Conrotto 2006, Hegarty 2002, Lin 2005, Choonhakarn 2008, and Voute 1993 reported partial response.

\section{(e) Relapse rate when medications are stopped or reduced}

Passeron 2007 and Conrotto 2006 reported relapse rate when medication was stopped.

\section{(f) Dermatology quality of life measures}

Only one study measured quality of life (Hegarty 2002) using the Oral Health Impact Profile (OHIP) and Oral Health QoL questionnaires (OHQOL). These two quality of life measurement tools are not specific to vulval disease.

\section{(i) Side-effects reported}

All of the included studies measured side-effects.

\section{(j) Reduction in target/mean lesion size (for oral lesions)}

Two studies reported a reduction in target/mean lesion size (Hegarty 2002; Radfar 2008).

\section{Excluded studies}

We excluded 36 studies, and the reasons for exclusion are listed in the 'Characteristics of excluded studies' tables.

Fifteen studies were excluded because initially they appeared to be RCTs, but on reading the full text, they were not RCTs.

Thirteen studies were not ELP, or recruited predominantly nonerosive subtypes of mucosal LP (e.g. reticulate LP).

The authors of a further three papers were contacted for further information on breakdown of data for the erosive subtype, but no response was received. Of these three, one study recruited participants with vulval LP (Rajar 2008). This was the only study looking at vulval LP, but only $82 \%$ of subjects had erosive lesions. We excluded this study because no data for the erosive subtype was available. In addition, details of the randomisation method were not available.

The remaining five studies were excluded for the following reasons: one was a split body-part design (Xia 2006);

one was a review (Lehman 2009);

one included participants with dysplasia (Scardina 2006);

one trial compared circuminoids as an adjunct to oral steroids (Chainani-Wu 2007); and

one trial investigating the use of ignatia, a homeopathic remedy for hysteria, only included participants with "the mind and general symptom of ignatia" (Mousavi 2009).

\section{Studies awaiting classification}

As a result of the final search, we have identified six potential trials, which are detailed in the 'Characteristics of studies awaiting classification' tables. These will be dealt with in a future update of this review.

\section{Ongoing Studies}

We found four ongoing studies when we ran our pre-publication search, details of which are in the 'Characteristics of ongoing studies' tables. These will be dealt with in a future update of this review.

\section{Risk of bias in included studies}

We independently analysed the risk of bias for each individual study. This is discussed in detail in the 'Characteristics of included studies' tables and summarised in Figure 1 and Figure 2. 
Figure I. 'Risk of bias' graph - review authors' judgements about each 'Risk of bias' item presented as percentages across all included studies.

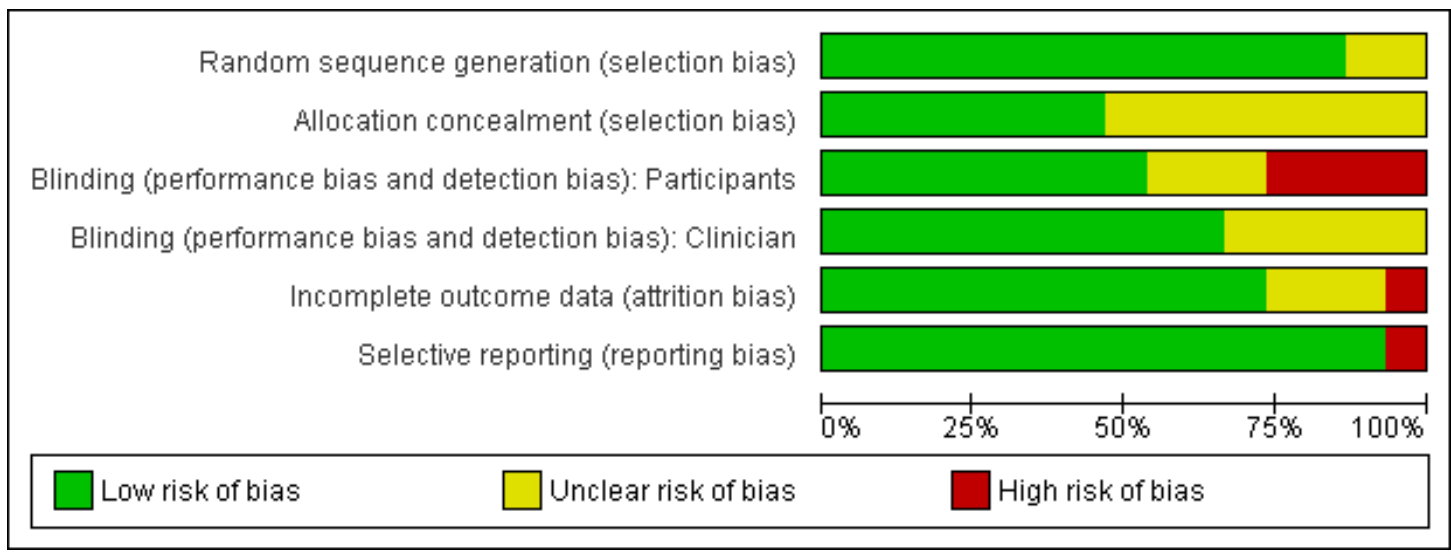


Figure 2. 'Risk of bias' summary - review authors' judgements about each 'Risk of bias' item for each included study.

\begin{tabular}{|c|c|c|c|c|c|c|}
\hline & 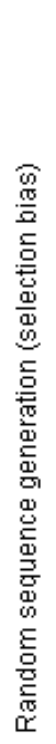 & 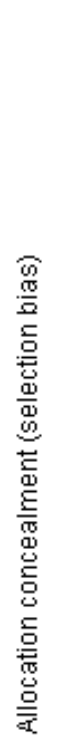 & 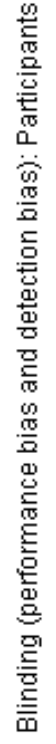 & 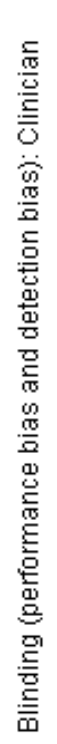 & 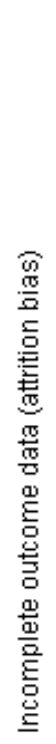 & 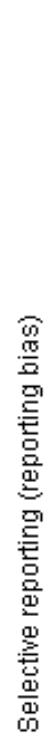 \\
\hline Campisi 2004 & + & $?$ & 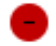 & + & $?$ & + \\
\hline Carbone 2009 & + & $?$ & + & + & $?$ & + \\
\hline Choonhakarn 2008 & + & + & + & + & + & + \\
\hline Conrotto 2006 & + & + & + & + & $?$ & + \\
\hline Eisen 1990 & + & $?$ & + & + & + & + \\
\hline Hegarty 2002 & + & $?$ & 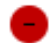 & + & + & \\
\hline $\operatorname{Lin} 2005$ & + & $?$ & $?$ & $?$ & + & + \\
\hline Malhotra 2008 & + & $?$ & - & $?$ & - & + \\
\hline Passeron 2007 & + & $?$ & $?$ & $?$ & + & + \\
\hline Radfar 2008 & + & + & + & + & + & + \\
\hline Sardella 1998 & + & $?$ & + & + & + & + \\
\hline Swift 2005 & + & + & + & + & + & + \\
\hline Volz 2008 & + & + & + & + & + & + \\
\hline Voute 1993 & $?$ & + & $?$ & $?$ & + & + \\
\hline Yoke 2006 & $?$ & + & - & $?$ & + & + \\
\hline
\end{tabular}




\section{Allocation}

The randomisation method was stated in all but two studies (Voute 1993; Yoke 2006), which were rated as unclear. The methods used included random number tables (Carbone 2009; Choonhakarn 2008; Conrotto 2006; Eisen 1990; Hegarty 2002; Lin 2005; Malhotra 2008; Radfar 2008; Sardella 1998; Swift 2005), block randomisation (Campisi 2004; Passeron 2007), and an automated system of assigning randomisation numbers (Volz 2008).

Allocation concealment was stated in seven studies via a central office pharmacy and was, therefore, judged at low risk of bias (Choonhakarn 2008; Conrotto 2006; Radfar 2008; Swift 2005; Volz 2008; Voute 1993; Yoke 2006).

\section{Blinding}

Campisi 2004, Hegarty 2002, Malhotra 2008, and Yoke 2006 were not blinded to participants for practical reasons relating to the mode of therapy administration or use of different bases. It was unclear if Lin 2005, Passeron 2007, and Voute 1993 were blinded to participants.

Ten studies were blinded to clinicians. It was unclear if Lin 2005, Malhotra 2008, Passeron 2007, Voute 1993, and Yoke 2006 were blinded.

\section{Incomplete outcome data}

Of the nine studies which recruited only ELP participants, six studies performed intention-to-treat (ITT) analyses (Hegarty 2002; Lin 2005; Passeron 2007; Swift 2005; Volz 2008; Radfar 2008), of which one study (Swift 2005) had two losses early on that were replaced before the study commenced. These six studies were rated as at low risk of bias for this domain. Three studies with losses did not appear to be ITT (Campisi 2004; Carbone 2009; Conrotto 2006) and were, thus, rated as at unclear risk of bias.

Of the six studies that recruited both ELP and non-ELP participants, five performed ITT analyses (Choonhakarn 2008; Eisen 1990; Sardella 1998; Voute 1993; Yoke 2006) and were rated as at low risk of bias for this domain. One study (Malhotra 2008) was rated as at high risk of bias for this domain because there were three losses to follow-up that were not included in the final analysis.

\section{Selective reporting}

Hegarty 2002 did not report any data on clinical score 0 to 5 (Thongprasom 1992), even though this was mentioned in their methods section "clinician (objective) assessment", so it was the only study rated as at high risk of bias for this domain.

\section{Other potential sources of bias}

We did not find any other potential sources of bias in any of the 15 included trials.

\section{Effects of interventions}

\section{Primary outcomes}

\section{(a) Pain reduction using a visual analogue scale (VAS) rated by participants}

All of the studies reported pain as a pain score, rather than a reduction in pain. Additionally, the outcome relates to the pain score at follow-up, and baseline scores were not taken into account for this review since using randomisation methods should eliminate differences at baseline between the two interventions groups.

In the Swift 2005 study $(\mathrm{n}=20)$, which compared $1 \%$ pimecrolimus cream against placebo for 4 weeks, no significant reduction in pain was seen (MD -3.30, 95\% CI -20.22 to 13.62) (see Analysis 1.1).

In the Passeron 2007 study $(\mathrm{n}=12)$, which compared $1 \%$ pimecrolimus cream against placebo, no significant reduction in basal pain (MD $0.16,95 \%$ CI -0.86 to 1.18 ) or pain when feeding (MD $0.34,95 \%$ CI -1.36 to 2.04 ) was seen (see Analysis 1.1).

In the Campisi 2004 study ( $\mathrm{n}=50$ recruited, but follow-up data was only available in 45 participants), $0.025 \%$ clobetasol propionate lipid-loaded microspheres were found to significantly reduce pain when compared to a conventional formulation $(0.025 \%$ lipophilic ointment in the hydrophilic phase) (MD -18.30, 95\% CI -28.57 to -8.03) (see Analysis 2.1). However, in the Sardella 1998 study $(\mathrm{n}=12)$, no significant reduction in pain was seen for $0.05 \%$ clobetasol propionate when compared to $5 \%$ mesalazine gel (MD $-0.83,95 \%$ CI -4.12 to 2.46 ) (see Analysis 2.1). Additionally, no significant difference in pain was seen when $0.025 \%$ was compared to $0.05 \%$ clobetasol propionate in the Carbone 2009 study ( $\mathrm{n}=30$ ) when comparing the mean scores (MD -0.26, 95\% CI -1.42 to 0.90 ) (see Analysis 2.1 ) or when defined as at least a $50 \%$ improvement (RR 0.89, 95\% CI 0.47 to 1.67 ) (see Analysis 2.2).

A significant difference in pain (MD 45.17, 95\% CI 8.73 to 81.61 ) (see Analysis 3.1) was seen in the small sub-sample of 11 ELP participants in the Yoke 2006 study in favour of ciclosporin solution when compared to $0.1 \%$ triamcinolone acetonide (potent topical steroid).

In the Radfar 2008 study comparing $0.1 \%$ tacrolimus against $0.05 \%$ clobetasol propionate, no significant reduction in pain was seen between the 2 groups (MD - $0.64,95 \%$ CI -1.91 to 0.63 ) (see Analysis 4.1). 
In the Choonhakarn 2008 study, aloe vera gel was 6 times more likely to result in at least $50 \%$ improvement in pain symptoms when compared to placebo (RR 6.16, 95\% CI 2.35 to 16.13) (see Analysis 5.1)

Additionally, in the Conrotto 2006 study comparing $1.5 \%$ ciclosporin against $0.025 \%$ clobetasol propionate, no significant difference was seen for at least a $50 \%$ improvement in pain (RR 0.47 , 95\% CI 0.17 to 1.32 ) (see Analysis 6.1).

In the Hegarty 2002 cross-over trial $(\mathrm{n}=22)$ comparing fluticasone propionate spray against betamethasone sodium phosphate mouthwash, no statistical testing of the comparison for the pain score (VAS 0 to 100 score) was reported within the paper; therefore, it is not clear whether the difference is statistically significant or not (fluticasone [mean score 19.8] versus betamethasone [mean score 26]).

Volz 2008 only presented data for baseline and P values for changes in scores for each of the treatment groups without $\mathrm{P}$ values comparing the scores between the treatment groups.

We were unable to extract data on participant-reported symptoms for Eisen 1990 because there was no breakdown of data for the ELP subgroup.

\section{(b) Physician Global Assessment (e.g. five-point)}

No significant differences were seen for improvement in clinical response (defined using the Thongprasom score) between the $0.025 \%$ clobetasol-17-propionate and $0.025 \%$ conventional formulation groups in the Campisi 2004 study (MD 0.00, 95\% CI -0.61 to 0.61 ) (see Analysis 2.3 ), between $0.025 \%$ clobetasol propionate and $0.05 \%$ clobetasol propionate groups in the Carbone 2009 study (MD 0.47, 95\% CI -0.26 to 1.20) (see Analysis 2.3), or between the $0.1 \%$ triamcinolone acetonide versus ciclosporin solution in the Yoke 2006 study (MD 0.61, 95\% CI -0.79 to 2.01) (see Analysis 3.2).

No significant differences were seen for improvements in clinical response (defined using the Thongprasom score) between the $0.025 \%$ and $0.05 \%$ clobetasol propionate groups in the Carbone 2009 study (RR 1.14, 95\% CI 0.56 to 2.35) (see Analysis 2.4), or between the aloe vera and placebo groups in the Choonhakarn 2008 study (RR 2.64, 95\% CI 0.11 to 61.54) (see Analysis 5.2). However, in the Conrotto 2006 study a significant difference was seen in favour of the $1.5 \%$ ciclosporin gel compared to $0.025 \%$ clobetasol propionate gel (RR 3.16, 95\% CI 1.00 to 9.93) (see Analysis 6.2).

In the Eisen 1990 study, a significant difference was seen for an improvement in the severity of the disease in favour of the ciclosporin group when compared to the vehicle (MD -1.40, 95\% CI -1.86 to -0.94) (see Analysis 6.3).

In the Lin 2005 study, no significant difference was seen for an improvement in clinical response (defined as remarkably effective) in favour of TGT when compared to THT (RR 0.55, 95\% CI 0.25 to 1.20 ) for grade I (erosive and ulcerative) lesions or for grade II (erosive) lesions (RR $0.73,95 \%$ CI 0.42 to 1.28 ) (see Analysis 7.1).

In the Malhotra 2008 study, a significant improvement in clinical severity was seen at the end of the trial (at 24 weeks) in favour of $0.1 \%$ topical triamcinolone acetonide paste when compared to betamethasone oral mini-pulse therapy (MD 1.78, 95\% CI 0.17 to 3.39) (see Analysis 9.1). However, no significant differences between the treatment groups were detected at earlier outcome timings.

In the Passeron 2007 study, no significant difference was seen for an improvement in clinical response (defined as surface of erosive lesions) between the $1 \%$ pimecrolimus and placebo groups (MD $-0.50,95 \%$ CI -1.39 to 0.39 ) (see Analysis 1.3 ).

In the Volz 2008 study, 1\% pimecrolimus cream was 7 times more likely to result in a strong improvement as rated by the Physician Global Assessment when compared to vehicle cream (RR 7.00, 95\% CI 1.04 to 46.95) (see Analysis 1.4).

In the Voute 1993 study, no significant difference in improvement in clinical response (defined as complete response) was seen between the fluocinonide and placebo groups (RR 4.67, 95\% CI 0.24 to 88.96) (see Analysis 8.1).

In the Swift 2005 study, no significant difference was seen for an improvement in clinical response (defined as a weighted sum of ulceration, erythema, and reticulation between the $1 \%$ pimecrolimus and placebo groups) (MD $-56.57 \mathrm{~mm}^{2}, 95 \% \mathrm{CI}-134.02$ to $20.88 \mathrm{~mm}^{2}$ ) (see Analysis 1.2 ).

\section{(c) Participant global self-assessment}

One study (Passeron 2007) assessed the participants global self-assessment using a 5-point scale, and found 5 out of 6 participants in the $1 \%$ pimecrolimus group rated their improvement as moderate or important, with the other participant rating no improvement. This was compared to 1 out of 6 participants in the placebo group who rated their improvement as moderate or important. Of the other 5 participants in this group, 2 rated their improvement as fair, 1 had no improvement, 1 was worse, and 1 gave no score (P $=0.316$, Fishers Exact test).

\section{Secondary outcomes}

Again, there was no consensus regarding secondary outcome measures (Table 2).

(a) Complete clinical response defined as the percentage of participants with complete resolution of clinical signs or symptoms

In the Volz 2008 study, the difference in complete clearance between participants randomised to $1 \%$ pimecrolimus cream or vehicle cream was not statistically significant (RR 3.50, 95\% CI 0.95 to 12.90) (see Analysis 1.5). 
(b) Partial response defined as the percentage of participants with at least $\mathbf{5 0 \%}$ improvement

In the Carbone 2009 study, no significant difference was seen for an improvement in clinical response (defined as partial or complete response) between the $0.025 \%$ and $0.05 \%$ doses of clobetasol propionate groups (RR $1.18,95 \%$ CI 0.82 to 1.70 ).

In the Conrotto 2006 study, a significant difference was seen for an improvement in clinical response (defined as partial or complete response) in favour of $1.5 \%$ ciclosporin gel when compared to $0.025 \%$ clobetasol propionate gel (RR $1.46,95 \%$ CI 1.04 to 2.04 ). In the Choonhakarn 2008 study, a significant difference in improvement in clinical response (defined as $50 \%$ or more improvement) was seen in favour of the aloe vera groups when compared to placebo (22/24 versus $1 / 21$, respectively) (RR $19.25,95 \% \mathrm{CI}$ 2.83 to 130.85$)$.

In the Lin 2005 study, a significant difference was seen in improvement in clinical response (defined as remarkably effective or effective) in favour of TGT when compared to THT (THT versus TGT - RR 0.18, 95\% CI 0.04 to 0.82) for grade I (erosive and ulcerative) lesions; however, no significant difference was seen for grade II (erosive) lesions (THT versus TGT - RR 0.29, 95\% CI 0.07 to 1.27 ).

In the Voute 1993 study, no significant difference in improvement in clinical response (defined as more than 33\% improvement) was seen between the fluocinonide and placebo groups (RR 3.00, 95\% CI 0.62 to 14.62 ).

\section{(c) Reduction in severity of flares}

No studies reported this outcome.

\section{(d) Reduction in number of flares}

No studies reported this outcome.

\section{(e) Relapse rate when medications are stopped or reduced}

In Passeron 2007's study ( $\mathrm{n}=12)$ comparing $1 \%$ pimecrolimus cream to placebo for 4 weeks to treat erosive oral lichen planus, all participants who improved during treatment relapsed within 1 month of ceasing treatment.

Topical clobetasol gave less stable results than ciclosporin when therapy ended and showed a higher incidence of side-effects ( Conrotto 2006) $(\mathrm{n}=40)$.

\section{(f) Dermatology quality of life measures}

In the Hegarty 2002 cross-over trial $(\mathrm{n}=22)$ comparing fluticasone propionate spray against betamethasone sodium phosphate mouthwash, no statistical testing of the comparison for the Oral Health Quality of Life index (OHQoL16) was reported within the paper. Therefore, it is not clear whether the difference is statistically significant or not (fluticasone [mean score 0.7 ] versus betamethasone [mean score -0.8]).

\section{(g) Restoration of sexual activity (of most relevance to genital sites)}

None of the included studies assessed the effectiveness of treatments of genital ELP; thus, this outcome was not reported.

\section{(h) Eating a normally varied diet (most relevant to oral involvement)}

No studies reported this outcome.

\section{(i) Side-effects reported}

Several side-effects were reported, but none were serious (see Table 3). With topical corticosteroids, the main side-effects were oral candidiasis and dyspepsia (Campisi 2004; Conrotto 2006; Malhotra 2008; Yoke 2006). Fluticasone propionate spray caused nausea, swollen mouth, bad taste and smell, dry mouth, and a sore throat (Hegarty 2002) in a small proportion of participants, but they did not necessitate withdrawal of therapy. There were no reported side-effects with topical mesalazine gel (Sardella 1998). Up to one-third of participants receiving betamethasone oral minipulse therapy reported transient oedema of the face, hands, and feet; epigastric discomfort; and fatigue (Malhotra 2008).

Two participants receiving aloe vera gel reported transient stinging and mild itching at lesions that disappeared after the first week (Choonhakarn 2008). Transient burning of mucosal surfaces during swishing of ciclosporin rinse was reported (Eisen 1990). Participants receiving topical ciclosporin reported rashes $(n=2)$, parotid (salivary gland) swelling $(\mathrm{n}=1)$, dyspepsia $(\mathrm{n}=3)$ (Conrotto 2006), and transient burning (Yoke 2006). Participants receiving pimecrolimus 1\% cream (Passeron 2007; Swift 2005) and tacrolimus $0.1 \%$ ointment (Radfar 2008) reported transient burning within the first 2 weeks, resulting in withdrawal of therapy in 1 participant in the latter study.

Menstrual disturbance was reported in six participants and leucopenia in one participant receiving tripterygium glycosides tablets (Lin 2005), which are known to be cytotoxic and unsuitable for individuals of child-bearing age.

\section{(j) Reduction in target/mean lesion size (for oral lesions)}

In the Hegarty 2002 cross-over trial $(\mathrm{n}=22)$ comparing fluticasone propionate spray against betamethasone sodium phosphate mouthwash, no statistical testing of the comparison for the mean surface area of lesions was reported within the paper; therefore, it is not clear whether the difference is statistically significant or not (fluticasone [mean score $547.2 \mathrm{~mm}^{2}$ ] versus betamethasone [mean score $\left.671.9 \mathrm{~mm}^{2}\right]$ ). 
In the Radfar 2008 study, no significant difference in lesion size was seen between the $0.1 \%$ tacrolimus and $0.025 \%$ clobetasol propionate groups (MD 0.00, 95\% CI -1.09 to 1.10 ).

\section{DISCUSSION}

\section{Summary of main results}

There are very few RCTs in the literature for the treatment of erosive lichen planus (ELP) affecting mucosal sites. Most RCTs that do exist focus only on oral disease. Topical potent steroids are the widely accepted first-line treatment, but no overwhelming evidence exists to support this. There is weak evidence that $0.025 \%$ clobetasol propionate lipid-loaded microspheres significantly reduce pain compared to conventional ointment in a study of 50 participants (however, outcome data were only available from 45 of the participants recruited). Ciclosporin solution reduced pain significantly compared to $0.1 \%$ triamcinolone acetonide in a small subset of 11 participants. Aloe vera gel was 6 times more likely to produce at least $50 \%$ improvement in pain compared to placebo. There was no significant difference in clinical severity rated by physicians or participants in any of the included studies (Carbone 2009; Conrotto 2006; Radfar 2008; Voute 1993; Yoke 2006).

This review suggests that there is only weak evidence for the effectiveness of any of the treatments for oral ELP. No evidence was found for genital ELP; this may be because studies on genital ELP are more difficult to conduct than oral ELP. In addition, the RCTs were heterogenous in disease definition, outcome variables, measurement scales, and assessment intervals; hence, pooling of data was not possible for meta-analysis. Three studies based their clinical diagnosis on the WHO criteria 1978 for oral precancerous lesions (Kramer 1978). This clearly defines their criteria for clinical assessment. However, there is no WHO criteria for the diagnosis of vulval ELP.

The most commonly used clinical severity tool was adopted from the criteria first used by Thongprasom 1992, although this is not validated and applies only to oral lesions. No validated clinical severity tool is available for genital lesions. The most commonly used symptom-scoring tool was a visual analogue scale (VAS) of 0 to 10 or 0 to 100 for pain, rated by participants. It has been suggested that the VAS is non-linear and prone to bias, which limits its use as a serial measure of pain (Langley 1985). One study utilised the McGill Pain Questionaire, which measures several dimensions of pain and may be a better alternative to VAS (Langley 1985). Severity and duration of lesions were reported in only two studies (Passeron 2007; Radfar 2008). This is important because new-onset, previously untreated lesions may respond more readily to treatment than long-standing refractory lesions, even after the wash-out period.
Therapeutic regimens were continued over four weeks to six months. All but one study (Lin 2005) had assessment intervals of two to four weeks during the trial period, which made assessments at baseline and at three months. Most of the outcome assessment points ended too early after the completion of the therapeutic regimen. Only 7 studies followed up participants after completion of the treatment regimen for 1 to 17 months (Campisi 2004; Carbone 2009; Conrotto 2006; Passeron 2007; Volz 2008; Voute 1993; Yoke 2006); hence, long-term data on relapse rate and sideeffects is unknown. This is important as ELP is a chronic, relapsing, and remitting condition, and many affected individuals flare on cessation of therapy.

\section{Overall completeness and applicability of evidence}

Most of the studies in this review had small numbers of participants (range 12 to 139). The majority of the studies were heterogenous in outcome variables and disease severity scoring tools. All of the included studies recruited participants with oral disease; almost half of the studies recruited participants with all types of OLP and presented data for the erosive subset. Pooling of data was not possible with any of the studies. More RCTs on a larger scale are needed, using standardised outcome measures and well-validated severity scoring tools in the oral and genital ELP populations.

\section{Quality of the evidence}

There were only a very small number of included RCTs, none of which included vulval ELP. All but three included studies specifically stated the method of randomisation. Only half of the included studies stated the method of allocation concealment. Blinding of participants was not possible in four studies as different delivery systems were used. Of the nine studies that recruited only ELP participants, six studies performed intention-to-treat (ITT) analyses. Of the six studies which recruited both ELP and nonELP participants, five performed ITT analyses.

\section{Potential biases in the review process}

Two authors (SCh and RM) reviewed the full texts separately using a data extraction proforma. Two authors (SCh and RM) independently confirmed eligibility, assessed quality, and extracted data. The method of randomisation was not clarified in three studies (Campisi 2004; Voute 1993; Yoke 2006). Where the allocation concealment method was not specified (in eight studies), no further clarification was sought. This may be a potential source of bias. 


\section{Agreements and disagreements with other studies or reviews}

A Cochrane review update on 'Interventions for oral lichen planus' has recently been published (Thongprasom 2011). The authors concluded that there is a lack of strong evidence supporting the effectiveness of any therapy for oral lichen planus. Another systematic review focusing on treatments used in oral LP (Zakrzewska 2005) concluded that due to small study sizes, lack of standardised outcome measures, and high likelihood of publication bias, the results are not reliable. These conclusions are similar to our study results in terms of lack of evidence of efficacy of any type of treatment for erosive lichen planus, small study sizes, and lack of standardised outcome measures.

\section{AUTHORS' CONCLUSIONS}

\section{Implications for practice}

There is a lack of strong evidence supporting the efficacy of any therapy for ELP affecting mucosal surfaces. Very few well-conducted RCTs exist for the treatment of ELP. Most of those that do exist come from the oral medicine literature with small numbers of participants. Even though topical steroids are universally used as first-line therapy for ELP, there is no overwhelming evidence for the efficacy of any single treatment.

\section{Implications for research}

We suggest that future studies should have standardised outcome variables that are clinically important to affected individuals, such as the use of a modified standardised dermatology quality of life
(QOL) questionnaire (e.g. the Dermatology Quality of Life Index [DLQI]), to measure the impact on daily activities of mucosal disease. Erosive lichen planus potentially interferes with daily activities, such as eating and sexual function; hence, QOL is an important parameter to measure. Moreover, many individuals may not necessarily divulge such difficulties in daily life due to embarrassment unless asked specifically; thus, this should be assessed routinely.

The measurement of clinical severity score and participant-rated symptom score should be performed using agreed and/or validated severity scoring tools, such as the scoring system validated for oral lichen planus (Escudier 2007). Studies including both oral and genital sites should be encouraged due to the pattern of the disease. We suggest the development of an agreed and/or validated combined severity scoring tool for oral and genital disease. In addition, there is a real need for well-designed RCTs on systemic therapy with newer biological agents for the treatment of severe ELP refractory to first-line treatment with topical steroids.

\section{ACKNOWLEDGEMENTS}

We would like to thank the Lichen Planus Support Group for their contribution to the review. We would also like to thank Paul Silcocks who was the statistical co-author on the protocol.

The Cochrane Skin Group editorial base would like to thank the following people who commented on this review: our Key Editor Sue Jessop, our Assistant Statistical Editor Matthew Grainge, our Methodological Editor Philippa Middleton, Sheelagh Littlewood and Fenella Wojnarowska who were the clinical referees, and Lynne Chadburn who was the consumer referee.

\section{R E F E R E N C E S}

\section{References to studies included in this review}

Campisi 2004 \{published data only\}

Campisi G, Giandalia G, De Caro V, Di Liberto C, Arico P, Giannola LI. A new delivery system of clobetasol-17propionate (lipid-loaded microspheres $0.025 \%$ ) compared with a conventional formulation (lipophilic ointment in a hydrophilic phase $0.025 \%$ ) in topical treatment of atrophic/ erosive oral lichen planus. A Phase IV, randomized, observer-blinded, parallel group clinical trial. British Journal of Dermatology 2004;150(5):984-90.

Carbone 2009 \{published data only\}

Carbone M, Arduino PG, Carrozzo M, Caiazzo G, Broccoletti R, Conrotto D, et al.Topical clobetasol in the treatment of atrophic-erosive oral lichen planus: a randomized controlled trial to compare two preparations with different concentrations. Journal of Oral Pathology \& Medicine 2009;38(2):227-33.

Choonhakarn 2008 \{published data only\}

Choonhakarn C, Busaracome P, Sripanidkulchai B, Sarakarn P. The efficacy of aloe vera gel in the treatment of oral lichen planus: a randomized controlled trial. British Journal of Dermatology 2008;158(3):573-7.

Conrotto 2006 \{published data only\}

Conrotto D, Carbone M, Carrozzo M, Arduino P, Broccoletti R, Pentenero M, et al.Ciclosporin vs. clobetasol in the topical management of atrophic and erosive oral lichen planus: a double-blind, randomized controlled trial. British Journal of Dermatology 2006;154(1):139-45.

Eisen 1990 \{published data only\}

Eisen D, Ellis CN, Duell EA, Griffiths CE, Voorhees JJ. Effect of topical ciclosporine rinse on oral lichen planus. A 
double-blind analysis. The New England Journal of Medicine 1990;323(5):290-4.

Hegarty 2002 \{published data only\}

Hegarty AM, Hodgson TA, Lewsey JD, Porter, SR. Fluticasone propionate spray and betamethasone sodium phosphate mouthrinse: a randomized crossover study for the treatment of symptomatic oral lichen planus. Journal of the American Academy of Dermatology 2002;47(2):271-9.

Lin 2005 \{published data only\}

Lin LM, Qi XM. Comparative observation on the effects of Radix tripterygium hypoglaucum tablet and Tripterygium glycosides tablet in treating erosive oral lichen planus. Chinese Journal of Integrative Medicine 2005;11(2):149-50.

Malhotra 2008 \{published data only\}

Malhotra AK, Khaitan BK, Sethuraman G, Sharma VK. Betamethasone oral mini-pulse therapy compared with topical triamcinolone acetonide $(0.1 \%)$ paste in oral lichen planus: A randomized comparative study. Journal of the American Academy of Dermatology 2008;58(4):596-602.

Passeron 2007 \{published data only\}

Passeron T, Lacour JP, Fontas E, Ortonne JP. Treatment of oral erosive lichen planus with $1 \%$ pimecrolimus cream: a double-blind, randomized, prospective trial with measurement of pimecrolimus levels in the blood. Archives of Dermatology 2007;143(4):472-6.

Radfar 2008 \{published data only\}

Radfar, L, Wild RC, Suresh L. A comparative treatment study of topical tacrolimus and clobetasol in oral lichen planus. Oral Surgery, Oral Medicine, Oral Pathology, Oral Radiology, \& Endodontics 2008;105(2):187-93.

Sardella 1998 \{published data only\}

Sardella A, Demarosi F, Oltolina A, Rimondini L, \& Carrassi A. Efficacy of topical mesalazine compared with clobetasol propionate in treatment of symptomatic oral lichen planus. Oral Diseases 1998;4(4):255-9.

Swift 2005 \{published data only\} Swift JC, Rees TD, Plemons JM, Hallmon WW, Wright JC. The effectiveness of $1 \%$ pimecrolimus cream in the treatment of oral erosive lichen planus. Journal of Periodontology 2005;76(4):627-35.

Volz 2008 \{published data only\} Volz T, Caroli U, Lüdtke H, Bräutigam M, Kohler-Späth $\mathrm{H}$, Röcken $\mathrm{M}$, et al.Pimecrolimus cream $1 \%$ in erosive oral lichen planus--a prospective randomized double-blind vehicle-controlled study. British Journal of Dermatology 2008;159(4):936-41.

Voute 1993 \{published data only\}

Voûte AB, Schulten EA, Langendijk PN, Kostense PJ, van der Waal I. Fluocinonide in an adhesive base for treatment of oral lichen planus. A double-blind, placebo-controlled clinical study. Oral Surgery, Oral Medicine, \& Oral Pathology 1993;75(2):181-5.

Yoke 2006 \{published data only\}

Yoke PC, Tin GB, Kim MJ, Rajaseharan A, Ahmed S, Thongprasom K, et al.A randomized controlled trial to compare steroid with ciclosporine for the topical treatment of oral lichen planus. Oral Surgery, Oral Medicine, Oral Pathology, Oral Radiology, \& Endodontics 2006;102(1): 47-55.

\section{References to studies excluded from this review}

Bouloc 2000 \{published data only\} Bouloc A, Revuz J, Bagot M, Wechsler J, Natta P. KH 1060 for the treatment of lichen planus: a multicenter, randomized, double-blind, vehicle-controlled study. Archives of Dermatology 2000;136(10):1272.

Buajeeb 1997 \{published data only\} Buajeeb W, Kraivaphan P, Pobrurksa C. Efficacy of topical retinoic acid compared with topical fluocinolone acetonide in the treatment of oral lichen planus. Oral Surgery, Oral Medicine, Oral Pathology, Oral Radiology, \& Endodontics 1997;83(1):21-5.

Buajeeb 2000 \{published data only\} Buajeeb W, Pobrurksa C, Kraivaphan P. Efficacy of fluocinolone acetonide gel in the treatment of oral lichen planus. Oral Surgery, Oral Medicine, Oral Pathology, Oral Radiology, \& Endodontics 2000;89(1):42-5.

Carbone 2003 \{published data only\} Carbone M, Goss E, Carrozzo M, Castellano S, Conrotto D, Broccoletti R, et al.Systemic and topical corticosteroid treatment of oral lichen planus: a comparative study with long-term follow-up. Journal of Oral Pathology \& Medicine 2003;32(6):323-9.

Chainani-Wu 2007 \{published data only\} Chainani-Wu N, Silverman Jr S, Reingold A, Bostrom A, Mc Culloch C, Lozada-Nur F, et al.A randomized, placebocontrolled, double-blind clinical trial of curcuminoids in oral lichen planus. Phytomedicine 2007;14(7-8):437-46.

Chang 2008 \{published data only\} Chang AL, Badger J, Rehmus W, Kimball AB. Alefacept for erosive lichen planus: a case series. Journal of Drugs in Dermatology 2008;7(4):379-83.

Corrocher 2008 \{published data only\} Corrocher G, Di Lorenzo G, Martinelli N, Mansueto P, Biasi D, Nocini PF, et al.Comparative effect of tacrolimus $0.1 \%$ ointment and clobetasol $0.05 \%$ ointment in patients with oral lichen planus. Journal of Clinical Periodontology 2008;35(3):244-9.

Gaeta 1994 \{published data only\} Gaeta GM, Serpico R, Femiano F, La Rotonda MI, Cappello B, Gombos F. Cyclosporin bioadhesive gel in the topical treatment of erosive oral lichen planus. International Journal of Immunopathology \& Pharmacology 1994;7(2):125-32.

Gorouhi 2007 \{published data only\} Gorouhi F, Solhpour A, Beitollahi JM, Afshar S, Davari P, Hashemi P, et al.Randomized trial of pimecrolimus cream versus triamcinolone acetonide paste in the treatment of oral lichen planus. Journal of the American Academy of Dermatology 2007;57(5):806-13. 
Goulet 2001 \{published data only\}

Goulet P, Perusse R. Efficacy of colchicine in the symptomatic treatment of oral lichen planus. Oral Surgery, Oral Medicine, Oral Pathology, Oral Radiology, \& Endodontics 2001;91(4):436.

Hersle 1982 \{published data only\}

Hersle K, Mobacken H, Sloberg K, Thilander H. Severe oral lichen planus: treatment with an aromatic retinoid (etretinate). British Journal of Dermatology 1982;106(1): $77-80$.

Kellett 1990 \{published data only\}

Kellett JK, Ead RD. Treatment of lichen planus with a short course of oral prednisolone letter. British Journal of Dermatology 1990;123(4):550-1.

Laeijendecker 2006 \{published data only\} Laeijendecker R, Tank B, Dekker SK, Neumann HA. A comparison of treatment of oral lichen planus with topical tacrolimus and triamcinolone acetonide ointment. Acta Dermato-Venereologica 2006;86(3):227-9.

Lehman 2009 \{published data only\} Lehman JS, Tollefson MM, Gibson LE. Lichen planus. International Journal of Dermatology 2009;48(7):682-94.

Lener 2001 \{published data only\}

Lener EV, Brieva J, Schachter M, West LE, West DP, elAzhary RA. Successful treatment of erosive lichen planus with topical tacrolimus. Archives of Dermatology 2001;137 (4):419-22.

Lo Muzio 2001 \{published data only\}

Lo Muzio L, della Valle A, Mignogna MD, Pannone G, Bucci P, Bucci E, et al.The treatment of oral aphthous ulceration or erosive lichen planus with topical clobetasol propionate in three preparations: a clinical and pilot study on 54 patients. Journal of Oral Pathology \& Medicine 2001; 30(10):611-7.

Lozada-Nur 1994 \{published data only\} Lozada-Nur F, Miranda C, Maliksi R. Double-blind clinical trial of $0.05 \%$ clobetasol propionate (corrected from proprionate) ointment in orabase and $0.05 \%$ fluocinonide ointment in orabase in the treatment of patients with oral vesiculoerosive diseases. Oral Surgery, Oral Medicine, Oral Pathology 1994;77(6):598-604.

Lozada-Nur 2006 \{published data only\}

Lozada-Nur FI, Sroussi HY. Tacrolimus powder in Orabase $0.1 \%$ for the treatment of oral lichen planus and oral lichenoid lesions: an open clinical trial. Oral Surgery, Oral Medicine, Oral Pathology, Oral Radiology, \& Endodontics 2006;102(6):744-9.

Ma 2004 \{published data only\}

Ma FK. Comparison of catechu and tripterygium hypoglaucum hutch tablet in treating oral lichen planus of erosion type. Shanghai Kou Qiang Yi Xue/Shanghai Journal of Stomatology 2004;13(4):348-9.

Mansourian 2008 \{published data only\}

Mansourian A, Sanatkhani M, Heravi FM. A randomized double blind controlled trial to compare metronidazole with doxycycline for the treatment of oral lichen planus. Journal of Medical Sciences 2008;8(2):201-4.

Mousavi 2009 \{published data only\} Mousavi F, Sherafati S, Mojaver YN. Ignatia in the treatment of oral lichen planus. Homeopathy: The Journal of the Faculty of Homeopathy 2009;98(1):40-4.

Nolan 2009 \{published data only\}

Nolan A, Badminton J, Maguire J, Seymour RA. The efficacy of topical hyaluronic acid in the management of oral lichen planus. Journal of Oral Pathology \& Medicine 2009;38(3):299-303.

Piattelli 2007 \{published data only\}

Piattelli A, Carinci F, Iezzi G, Perrotti V, Goteri G, Fioroni $\mathrm{M}$, et al.Oral lichen planus treated with 13-cis-retinoic acid (isotretinoin): effects on the apoptotic process. Clinical Oral Investigations 2007;11(3):283-8.

Rajar 2008 \{published data only\} Rajar UD, Majeed R, Parveen N, Sheikh I, Sushel C. Efficacy of aloe vera gel in the treatment of vulval lichen planus. Journal of the College of Physicians \& Surgeons-Pakistan : JCPSP 2008;18(10):612-4.

Rödström 1994 \{published data only\} Rödström PO, Hakeberg M, Jontell M, Nordin P. Erosive oral lichen planus treated with clobetasol propionate and triamcinolone acetonide in Orabase: A double-blind clinical trial. Journal of Dermatological Treatment 1994;5(1):7-10.

Scardina 2006 \{published data only\} Scardina GA, Messina P, Carini F, Maresi E. A randomized trial assessing the effectiveness of different concentrations of isotretinoin in the management of lichen planus. International Journal of Oral and Maxillofacial Surgery 2006 35(1):67-71.

Scheer 2006 \{published data only\} Scheer M, Kawari-Mahmoodi N, Neugebauer J, Kubler AC Pimecrolimus (Elidel) for therapy of lichen ruber mucosae [Pimecrolimus (ELIDEL) Zur Behandlung Des Lichen Planus Mucosae]. Mund-, Kiefer-Und Gesichtschirurgie 2006;10(6):403-7.

Sieg 1995 \{published data only\}

Sieg P, Von Domarus H, Von Zitzewitz V, Iven H, Farber L. Topical ciclosporin in oral lichen planus: a controlled, randomized, prospective trial. British Journal of Dermatology 1995;132(5):790-4.

Silver 1991 \{published data only\} Silverman S Jr, Gorsky M, Lozada Nur F, Giannotti K. A prospective study of findings and management in 214 patients with oral lichen planus. Oral Surgery, Oral Medicine and Oral Pathology 1991;72(6):665-70.

Thongprasom 2003 \{published data only\} Thongprasom K, Luengvisut P, Wongwatanakij A, Boonjatturus C. Clinical evaluation in treatment of oral lichen planus with topical fluocinolone acetonide: A 2-year follow-up. Journal of Oral Pathology \& Medicine 2003;32 (6):315-22. 
Thongprasom 2007 \{published data only\}

Thongprasom K, Chaimusig M, Korkij W, Sererat T, Luangjarmekorn L, Rojwattanasirivej S. A randomizedcontrolled trial to compare topical ciclosporin with triamcinolone acetonide for the treatment of oral lichen planus. Journal of Oral Pathology \& Medicine 2007;36(3): $142-6$.

Tyldesley 1977 \{published data only\}

Tyldesley WR, Harding SM. Betamethasone valerate aerosol in the treatment of oral lichen planus. British Journal of Dermatology 1977;96(6):659-62.

Ungphaiboon 2005 \{published data only\} Ungphaiboon S, Nittayananta W, Vuddhakul V, Maneenuan D, Kietthubthew S, Wongpoowarak W, et al.Formulation and efficacy of triamcinolone acetonide mouthwash for treating oral lichen planus. American Journal of HealthSystem Pharmacy 2005;62(5):485-91.

Wei 2003 \{published data only\} Wei X, Li BQ, Zhou XD, Chen QM. Clinical effect of mycostatin paste plus dexamethasone paste in treatment of patients with OLP. Journal of Clinical Stomatology 2003;19 (9):568-9.

Xia 2006 \{published data only\}

Xia J, Li C, Hong Y, Yang L, Huang Y, Cheng B. Short-term clinical evaluation of intralesional triamcinolone acetonide injection for ulcerative oral lichen planus. Journal of Oral Pathology \& Medicine 2006;35(6):327-31.

Xu 2002 \{published data only\}

Xu YZ, GY, Liu YX, Fuan YQ, Li J. Clinical study on threestep treatment of oral lichen planus by integrated traditional and western medicine. Journal of Modern Stomatology 2002; 16(4):344-6.

\section{References to studies awaiting assessment}

\section{Agha-Hosseini 2010 \{published data only\}}

Agha-Hosseini F, Borhan-Mojabi K, Monsef-Esfahani HR, Mirzaii-Dizgah I, Etemad-Moghadam S, Karagah A. Efficacy of purslane in the treatment of oral lichen planus. Phytotherapy Research 2010;24(2):240-4.

Cilurzo 2010 \{published data only\}

Cilurzo F, Gennari CGM, Selmin F, Epstein JB, Gaeta GM, Colella G, et al.A new mucoadhesive dosage form for the management of oral lichen planus: formulation study and clinical study. European Journal of Pharmaceutics \& Biopharmaceutics 2010;76(3):437-42.

Javadzadeh 2008 \{published data only\} Javadzadeh A, Vatanpour H, Delavarian Z, Momajed A, Esmaeily H, Vatanpour M, et al.Efficacy of clobetasol, ketoconazole and amitryptiline mouthwash on Oral Lichen Planus. Iranian Journal of Pharmaceutical Research 2008;7 (3):171-8

Salazar-Sanchez 2010 \{published data only\} Salazar-Sanchez N, Lopez-Jornet P, Camacho-Alonso F, Sanchez-Siles M. Efficacy of topical Aloe vera in patients with oral lichen planus: a randomized double-blind study. Journal of Oral Pathology \& Medicine 2010;39(10):735-40.

Wu 2010 \{published data only\}

Wu Y, Zhou G, Zeng H, Xiong CR, Lin M, Zhou HM. A randomized double-blind, positive-control trial of topical thalidomide in erosive oral lichen planus. Oral Surgery, Oral Medicine, Oral Pathology, Oral Radiology, \& Endodontics 2010;110(2):188-95.

\section{Xiong 2009 \{published data only\}}

Xiong C, Li Q, Lin M, Li X, Meng W, Wu Y, et al.The efficacy of topical intralesional BCG-PSN injection in the treatment of erosive oral lichen planus: a randomized controlled trial. Journal of Oral Pathology \& Medicine 2009; 38(7):551-8.

\section{References to ongoing studies}

\section{NCT00135733 \{published data only\}}

NCT00135733. A Randomized, Double-Blind, PlaceboControlled Pilot Study of the Efficacy and Safety of Alefacept in the Treatment of Moderate to Severe Erosive Mucosal Lichen Planus. http://clinicaltrials.gov/ct2/show/ NCT00135733 (accessed 26 June 2011).

\section{NCT01061853 \{published data only\}}

NCT01061853. Efficacy of Topical Rapamycin in The Treatment of Chronic Erosive Oral Lichen Planus. Double Blind Randomised Controlled Trial Rapamycin vs Topical Steroids. http://clinicaltrials.gov/ct2/show/NCT01061853 (accessed 26 June 2011).

\section{NCT01282515 \{published data only\}}

NCT01282515. A Study of Topical Hexaminolevulinate (HAL) Photodynamic Therapy (PDT) and a Phase III Comparative Treatment Study of HAL PDT in Female Genital Erosive Lichen Planus (GELP). http:// clinicaltrials.gov/ct2/show/NCT01282515 (accessed 26 June 2011)

\section{NCT01375101 \{published data only\}}

NCT01375101. Therapeutic Effect of Quercetin and the Current Treatment of Erosive and Atrophic Oral Lichen Planus. http://clinicaltrials.gov/ct2/show/NCT01375101 (accessed 26 June 2011).

\section{Additional references}

\section{Abraham 2000}

Abraham SC, Ravich WJ, Anhalt GJ, Yardley JH, Wu TT. Esophageal lichen planus: case report and review of the literature. The American Journal of Surgical Pathology 2000; 24(12):1678-82.

Bain 1989

Bain L, Geronemus R. The association of lichen planus of the penis with squamous cell carcinoma in situ and with verrucous squamous cell carcinoma. Journal of Dermatologic Surgery and Oncology 1989;15(4):413-7.

\section{Baldo 2010}

Baldo M, Bailey A, Bhogal B, Groves RW, Wojnarowska F. T cells reactive with the NC16A domain of BP180 are 
present in vulval lichen sclerosus and lichen planus. Journal of the European Academy of Dermatology and Venereology 2010;24(2):186-90.

\section{Boyd 1991}

Boyd AS, Neldner KH. Lichen planus. Journal of the American Academy of Dermatology 1991;25(4):593-619.

\section{Breathnach 2004}

Breathnach SM, Black MM. Lichen Planus and Lichenoid Disorders. In: Burns DA, Breathnach SM, Cox N, Griffiths CE editor(s). Rook's Textbook of Dermatology. 7th Edition. Vol. 3, Blackwell Publishing, 2004:42.6-42.8.

\section{Camisa 2000}

Camisa C, Popovsky JL. Effective treatment of oral erosive lichen planus with thalidomide. Archives of Dermatology 2000;136(12):1442-3.

\section{Carrozzo 2008}

Carrozzo M. How common is oral lichen planus?. EvidenceBased Dentistry 2008;9(4):112-3.

\section{Cheng 2006}

Cheng A, Mann C. Oral erosive lichen planus treated with efalizumab. Archives of Dermatology 2006;142(6):680-2.

\section{Cooper 2006}

Cooper SM, Wojnarowska F. Influence of treatment of erosive lichen planus of the vulva on its prognosis. Archives of Dermatology 2006;142(3):289-94.

\section{Cribier 1993}

Cribier B, Ndiaye I, Grosshans E. Peno-gingival syndrome. A male equivalent of vulvo-vagino-gingival syndrome? [Syndrome peno-gingival: Un equivalent masculine du syndrome vulvo-vagino-gingival?]. Revue de Stomatologie et de Chirurgie Maxillo-Faciale 1993;94(3):148-51.

\section{Eisen 1999}

Eisen D. The evaluation of cutaneous, genital, scalp, nail, esophageal, and ocular involvement in patients with oral lichen planus. Oral Surgery, Oral Medicine, Oral Pathology, Oral Radiology \& Endodontics 1999;88(4):431-6.

\section{Escudier 2007}

Escudier M, Ahmed N, Shirlaw P, Setterfield J, Tappuni A, Black MM, et al.A scoring system for mucosal disease severity with special reference to oral lichen planus. British Journal of Dermatology 2007;157(4):765-70.

\section{Gandolfo 2004}

Gandolfo S, Richiardi L, Carrozzo M, Broccoletti R, Carbone M, Pagano M, et al.Risk of oral squamous cell carcinoma in 402 patients with oral lichen planus: a followup study in an Italian population. Oral Oncology 2004;40 (1):77-83.

\section{Heffernan 2007}

Heffernan MP, Smith DI, Bentley D, Tabacchi M, Graves JE. A single-center, open-label, prospective pilot study of subcutaneous efalizumab for oral erosive lichen planus. Journal of Drugs in Dermatology 2007;6(3):310-4.

\section{Higgins 2011}

Higgins JPT, Green S (editors). Cochrane Handbook for Systematic reviews of Interventions 5.1.0 [updated March 2011]. The Cochrane Collaboration, 2011. Available from www.cochrane-handbook.org, 2011.

\section{Holmstrup 1988}

Holmstrup P, Thorn JJ, Rindum J, Pindborg JJ. Malignant development of lichen planus-affected oral mucosa. Journal of Oral Pathology 1988;17(5):219-25.

\section{Jang 2008}

Jang N, Fischer G. Treatment of erosive vulvovaginal lichen planus with methotrexate. Australasian Journal of Dermatology 2008;49(4):216-9.

\section{Kaliakatsou 2002}

Kaliakatsou F, Hodgson TA, Lewsey JD, Hegarty AM, Murphy AG, Porter SR. Management of recalcitrant ulcerative oral lichen planus with topical tacrolimus. Journal of the American Academy of Dermatology 2002;46(1):35-41.

\section{Kramer 1978}

Kramer IR, Lucas RB, Pindborg JJ, Sobin LH. Definition of leukoplakia and related lesions: an aide to studies on oral precancer. Oral Surgery Oral Medicine and Oral Pathology 1978;46(4):518-39.

\section{Langley 1985}

Langley GB, Sheppeard H. The visual analogue scale: Its use in pain measurement. Rheumatology International 1985; 5(4):145-8.

Leal-Khouri 1994

Leal-Khouri S, Hruza GJ. Squamous cell carcinoma developing within lichen planus of the penis: treatment with Mohs micrographic surgery. Journal of Dermatological Surgery and Oncology 1994;20(4):272-6.

\section{Lewis 1994}

Lewis FM, Harrington CI. Squamous cell carcinoma arising in vulval lichen planus. British Journal of Dermatology 1994; 131(5):703-5.

\section{Lo Muzio 1998}

Lo Muzio L, Mignogna MD, Favia G, Procaccini M, Testa NF, Bucci E. The possible association between oral lichen planus and oral squamous cell carcinoma: a clinical evaluation on 14 cases and review of literature. Oral Oncology 1998;34(4):239-46.

\section{Lundquist 1995}

Lundquist G, Forsgren H, Gajecki M, Emtestam L. Photochemotherapy of oral lichen planus. A controlled study. Oral Surgery, Oral Medicine, Oral Pathology, Oral Radiology \& Endodontics 1995;79(5):554-8.

Neumann 1993

Neumann R, Dutt CJ, Foster CS. Immunohistopathologic features and therapy of conjunctival lichen planus. American Journal of Ophthalmology 1993;115(4):494-500.

\section{Pelisse 1982}

Pelisse M, Leibowitch M, Sedel D, Hewitt J. A new vulvovaginogingival syndrome. Plurimucous erosive lichen 
planus [Un noveau syndrome vulvo-vagino-gingival. Lichen planerosif plurimuqueux]. Annales de Dermatologie et de Venereologie 1982;109(9):797-8.

\section{Pelisse 1989}

Pelisse M. The vulvo-vaginal-gingival syndrome: a new form of erosive lichen planus. International Journal of Dermatology 1989;28(6):381-4.

Porter 1997

Porter SR, Kirby A, Olsen I, Barrett W. Immunologic aspects of dermal and oral lichen planus: a review. Oral Surgery, Oral Medicine, Oral Pathology, Oral Radiology \& Endodontics 1997;83(3):358-66.

\section{Scully 2008}

Scully C, Carrozzo M. Oral mucosal disease: lichen planus. British Journal of Oral and Maxillofacial Surgery 2008;46(1): 15-21.

\section{Silverman 1985}

Silverman S, Gorsky M, Lozada-Nur F. A prospective follow up study of 570 patients with oral lichen planus: persistence, remission, and malignant association. Oral Surgery, Oral Medicine, Oral Pathology 1985;60(1):30-4.

\section{Soria 2009}

Soria A, Agbo-Godeau S, Taïeb A, Francès C. Treatment of refractory oral erosive lichen planus with topical rapamycin: 7 cases. Dermatology 2009;218(1):22-5.

\section{Thongprasom 1992}

Thongprasom K, Luangjarmekorn L, Sererat T, Taweesap W. Relative efficacy of fluocinolone acetonide compared with triamcinolone acetonide in treatment of oral lichen planus. Journal of Oral Pathology \& Medicine 1992;21(10): 456-8.

\section{Thongprasom 2011}

Thongprasom K, Carrozzo M, Furness S, Lodi G. Interventions for treating oral lichen planus. Cochrane Database of Systematic Reviews 2011, Issue 7. [DOI: 10.1002/14651858.CD001168.pub2]

\section{Thornhill 2001}

Thornhill MH. Immune mechanisms in oral lichen planus. Acta Odontologica Scandinavica 2001;59(3):174-7.

\section{Zakrzewska 2005}

Zakrzewska JM, Chan ES, Thornhill MH. A systematic review of placebo-controlled randomised clinical trials of treatments used in oral lichen planus. British Journal of Dermatology 2005;153(2):336-41.

* Indicates the major publication for the study 


\section{CHARACTERISTICS OF STUDIES}

\section{Characteristics of included studies [ordered by study ID]}

\section{Campisi 2004}

Methods

Phase IV, randomised, observer-blinded, parallel group clinical trial

Setting

Section of Oral Medicine, Department of Oral Sciences, University of Palermo, Italy

Participants

\section{Inclusion criteria of the trial}

Symptomatic atrophic/erosive OLP clinically and histology, no previous treatment in past 6 months

Total $\mathrm{n}=50$ (lipid-loaded microspheres $0.025 \%-\mathrm{n}=20$, conventional formulation ointment $-\mathrm{n}=30$ )

Interventions

Comparison of drug delivery system of clobetasol-17-propionate

A: Lipid-loaded microspheres $0.025 \%$

B: Conventional formulation lipophilic ointment in hydrophilic phase $0.025 \%$

Applied twice daily for 1 month then once daily for 1 month

\begin{tabular}{|c|c|}
\hline \multirow[t]{7}{*}{ Outcomes } & Primary outcomes of the trial \\
\hline & $\overline{1 . \text { VAS } 0 \text { to } 100}$ \\
\hline & 2. Clinical score 0 to 5 (Thongprasom 1992) \\
\hline & 3. Not assessed \\
\hline & Secondary outcomes of the trial \\
\hline & 1. Clinical resolution of index lesion \\
\hline & Outcomes not prespecified in the protocol \\
\hline
\end{tabular}

\begin{tabular}{l|l} 
Assessment points $\quad$ Week 0,4 , and 8
\end{tabular}

Side-effects reported

Oral candidiasis ( 1 in lipid-loaded microspheres group, 2 in conventional ointment group)

Reported results

No significant difference between the 2 groups

Notes

\section{Risk of bias}

\begin{tabular}{l|ll}
\hline Bias & Authors' judgement & Support for judgement \\
\hline $\begin{array}{l}\text { Random sequence generation (selection } \\
\text { bias) }\end{array}$ & Low risk & Block randomisation. \\
\hline Allocation concealment (selection bias) & Unclear risk & Not specifically stated.
\end{tabular}

$\begin{array}{lll}\text { Allocation concealment (selection bias) } \quad \text { Unclear risk } & \text { Not specifically stated. }\end{array}$ 


\section{Campisi 2004 (Continued)}

\begin{tabular}{l|l|l}
\hline $\begin{array}{l}\text { Blinding (performance bias and detection } \\
\text { bias) } \\
\text { Participants }\end{array}$ & High risk & Participants not blinded (different bases). \\
\hline $\begin{array}{l}\text { Blinding (performance bias and detection } \\
\text { bias) } \\
\text { Clinician }\end{array}$ & Low risk & $\begin{array}{l}\text { Quote: “A single blind observer...different } \\
\text { from the administrator..." }\end{array}$ \\
\hline $\begin{array}{l}\text { Incomplete outcome data (attrition bias) } \\
\text { All outcomes }\end{array}$ & Unclear risk & $\begin{array}{l}\text { Loss to follow-up: } 5 \text { losses, } 50 \text { randomised. } \\
\text { No ITT. }\end{array}$ \\
\hline \begin{tabular}{l} 
Selective reporting (reporting bias) \\
\hline
\end{tabular} & Low risk & All 4 outcomes reported. \\
\hline
\end{tabular}

Carbone 2009

Methods

Randomised controlled trial to compare 2 preparations with different concentrations Setting

Oral Medicine Section of the Department of Biological Sciences and Human Oncology, Univerisity of Turin

$\begin{array}{ll}\text { Participants } & \begin{array}{l}\text { Inclusion criteria of the trial } \\ \text { Histological diagnosis of OLP on the basis of WHO criteria, presence of painful and } \\ \text { atrophic-erosive oral lesions at the same time as with reticular ones } \\ \text { Total } \mathrm{n}=35(\operatorname{arm} 1-\mathrm{n}=18, \text { arm } 2-\mathrm{n}=17)\end{array}\end{array}$

Interventions

A: Topical clobetasol propionate $0.025 \%$ (arm 1)

B: Clobetasol propionate $0.05 \%$ (arm 2)

Applied twice daily for 2 months and antimyotic prophylaxis for both groups

Outcomes

Primary outcomes of the trial

1. Symptoms (VAS 0 to 10 )

Symptom response at end of treatment (week 8) compared to baseline defined as follows:

- Complete response = absence of any discomfort or symptoms

- Partial response $=$ decrease in VAS

- Worsening = increase in VAS

- Persisting = no change in VAS

2. Clinical score 0 to 5 (Thongprasom 1992)

- Complete response $=$ disappearance of all lesions

- Partial response = decrease score

- Worsening = increase score

- Persisting $=$ no change in score

3. Not assessed

Outcomes not prespecified in the protocol

- Stability of the obtained results in the 8 weeks following suspension of treatment

Assessment points $\quad$ Week 0, 2, 4, 6, 8, and 16

Side-effects reported

None reported 
Carbone 2009 (Continued)

\begin{tabular}{l|l} 
Reported results & $\begin{array}{l}\text { Clinical score/response and VAS (no significant difference between the } 2 \text { groups at } 2 \\
\text { months) }\end{array}$ \\
\hline Notes & $\begin{array}{l}\text { Excluded skin, genital, or other extra-oral lesions } \\
\text { Clobetasol propionate } 0.05 \% \text { (Clobesol, Glaxo, Verona, Italy) is the drug that is com- } \\
\text { mercially available }\end{array}$ \\
\hline
\end{tabular}

\section{Risk of bias}

\begin{tabular}{|c|c|c|}
\hline Bias & Authors' judgement & Support for judgement \\
\hline $\begin{array}{l}\text { Random sequence generation (selection } \\
\text { bias) }\end{array}$ & Low risk & $\begin{array}{l}\text { Computer-generated random number ta- } \\
\text { bles. }\end{array}$ \\
\hline Allocation concealment (selection bias) & Unclear risk & Not specifically stated. \\
\hline $\begin{array}{l}\text { Blinding (performance bias and detection } \\
\text { bias) } \\
\text { Participants }\end{array}$ & Low risk & $\begin{array}{l}\text { During treatment neither the physician nor } \\
\text { the participants knew exactly which of the } \\
2 \text { medications they were using }\end{array}$ \\
\hline $\begin{array}{l}\text { Blinding (performance bias and detection } \\
\text { bias) } \\
\text { Clinician }\end{array}$ & Low risk & $\begin{array}{l}\text { During treatment neither the physician nor } \\
\text { the participants knew exactly which of the } \\
2 \text { medications they were using }\end{array}$ \\
\hline $\begin{array}{l}\text { Incomplete outcome data (attrition bias) } \\
\text { All outcomes }\end{array}$ & Unclear risk & $\begin{array}{l}\text { Loss to follow-up: } 35 \text { randomised, } 5 \text { losses } \\
\text { due to personal reasons ( } 3 \text { in arm } 1,2 \text { in } \\
\text { arm 2) - not included in final analysis }\end{array}$ \\
\hline Selective reporting (reporting bias) & Low risk & $\begin{array}{l}\text { Symptom response, clinical response, and } \\
\text { stability of results reported }\end{array}$ \\
\hline
\end{tabular}

Choonhakarn 2008

\begin{tabular}{ll}
\hline Methods & $\begin{array}{l}\text { Randomised controlled trial } \\
\text { Author contacted (c_choonhakarn_dermatologist@hotmail.com) - replied with break- } \\
\text { down of data for erosive subtype } \\
\text { Setting }\end{array}$ \\
\hline $\begin{array}{l}\text { Division of Dermatology, Srinagarind Hospital, Faculty of Medicine, Khon Kaen Uni- } \\
\text { versity }\end{array}$ \\
\hline Participants & $\begin{array}{l}\text { Inclusion criteria of the trial } \\
\text { Clinical and histological diagnosis of oral LP over } 18 \text { years } \\
\text { Total } \mathrm{n}=54 \text { (only } 45 \text { had erosive/atrophic LP, of which } \mathrm{n}=24 \text { in aloe vera group, } \mathrm{n}= \\
21 \text { in placebo group) }\end{array}$ \\
\hline Interventions & $\begin{array}{l}\text { A: Aloe vera (AV) gel } \\
\text { B: Placebo gel }\end{array}$
\end{tabular}


Applied twice daily for 8 weeks

\begin{tabular}{|c|c|}
\hline Outcomes & $\begin{array}{l}\text { Primary outcomes of the trial } \\
\text { 1. VAS } 0 \text { to } 10 \\
\text { Symptom response at end of treatment (week } 8 \text { ) defined as follows: } \\
\text { - Complete response = VAS of } 0 \\
\text { - Good response = VAS decrease by } 50 \% \text { or more from baseline } \\
\text { - Poor response = VAS decrease by }<50 \% \text { from baseline } \\
\text { - No response = VAS unchanged } \\
\text { 2. Clinical score } 0 \text { to } 5 \text { (Thongprasom } 1992 \text { ) } \\
\text { Clinical response at end of treatment (week } 8 \text { ) defined as follows: } \\
\text { - Complete response = score } 0 \text { to } 1 \\
\text { - Good response = score decrease by } 50 \% \text { or more from baseline } \\
\text { - Poor response = score decrease by }<50 \% \text { from baseline } \\
\text { - No response = unchanged } \\
\text { 3. Not assessed }\end{array}$ \\
\hline
\end{tabular}

Week $0,2,4,6$, and 8

Side-effects reported

No serious side-effects. 2 receiving aloe vera gel reported stinging and mild itching at lesions within the first week, but symptoms spontaneously disappeared with continued use

Reported results

No reported results for erosive subgroup of participants as trial included non-erosive OLP

Notes

Risk of bias

\section{Bias}

Random sequence generation (selection Low risk bias)
Low risk

\section{Support for judgement}

Simple random number tables.

AV gel and placebo gel were prepared by the Faculty of Pharmaceutical Sciences, Khon Kaen province. The study medications were packed in identical containers, and the code was kept at the Faculty of Pharmaceutical Sciences until completion of the study

Blinding (performance bias and detection Low risk bias)

Participants
The medication used was unknown to participants or physicians 


\section{Choonhakarn 2008 (Continued)}

\begin{tabular}{l|l|l}
$\begin{array}{l}\text { Blinding (performance bias and detection } \\
\text { bias) } \\
\text { Clinician }\end{array}$ & Low risk & $\begin{array}{l}\text { The medication used was unknown to par- } \\
\text { ticipants or physicians }\end{array}$ \\
\hline $\begin{array}{l}\text { Incomplete outcome data (attrition bias) } \\
\text { All outcomes }\end{array}$ & Low risk & No losses to follow-up. \\
\hline Selective reporting (reporting bias) & Low risk & Symptom and clinical response reported. \\
\hline
\end{tabular}

Conrotto 2006

\begin{tabular}{|c|c|}
\hline Methods & $\begin{array}{l}\text { Randomised controlled, double-blind study } \\
\text { Setting } \\
\text { Oral Medicine Section of the Department of Biological Sciences and Human Oncology, } \\
\text { University of Turin }\end{array}$ \\
\hline Participants & $\begin{array}{l}\text { Inclusion criteria of the trial } \\
\text { Oral lichen planus on the basis of WHO criteria, atrophic/erosive type (duration not } \\
\text { stated) } \\
\text { Total } n=40 \text { (clobetasol }-\mathrm{n}=20 \text {, ciclosporin }-\mathrm{n}=20 \text { ) }\end{array}$ \\
\hline Interventions & $\begin{array}{l}\text { A: Clobetasol topical } 0.025 \% \text { gel } \\
\text { B: Ciclosporin topical } 1.5 \% \text { gel } \\
\text { Applied twice daily for } 2 \text { months (same scoop) in the same base (hydroxyethyl cellulose } \\
\text { adhesive gel) }\end{array}$ \\
\hline Outcomes & $\begin{array}{l}\text { Primary outcomes of the trial } \\
\text { 1. VAS } 0 \text { to } 10 \\
\text { 2. Clinical score } 0 \text { to } 5 \text { (Thongprasom 1992) } \\
\text { Symptom and clinical response at end point compared with baseline: } \\
\text { - Complete response = disappeared } \\
\text { - Partial = decrease score } \\
\text { - No change = same score } \\
\text { - Worse = increase score } \\
\text { 3. Not assessed }\end{array}$ \\
\hline Assessment points & Fortnightly for 4 months \\
\hline Side-effects reported & $\begin{array}{l}\text { Ciclosporin: Skin rashes (2), parotid swelling (1), and dyspepsia (3) } \\
\text { Clobetasol: Dyspepsia (1) }\end{array}$ \\
\hline Reported results & $\begin{array}{l}\text { Topical Dermovate better than topical ciclosporin in inducing clinical improvement, but } \\
\text { both drugs had comparable effects on symptoms }\end{array}$ \\
\hline Notes & - \\
\hline
\end{tabular}

Risk of bias 


\section{Conrotto 2006 (Continued)}

\begin{tabular}{|c|c|c|}
\hline Bias & Authors' judgement & Support for judgement \\
\hline $\begin{array}{l}\text { Random sequence generation (selection } \\
\text { bias) }\end{array}$ & Low risk & $\begin{array}{l}\text { Computer-generated random number ta- } \\
\text { bles. }\end{array}$ \\
\hline Allocation concealment (selection bias) & Low risk & $\begin{array}{l}\text { Medication was distributed in identical } \\
\text { containers, packed by someone who was } \\
\text { unaware of the study }\end{array}$ \\
\hline $\begin{array}{l}\text { Blinding (performance bias and detection } \\
\text { bias) } \\
\text { Participants }\end{array}$ & Low risk & $\begin{array}{l}\text { During treatment neither the physician nor } \\
\text { the participants knew which of the } 2 \text { med- } \\
\text { ications they were using }\end{array}$ \\
\hline $\begin{array}{l}\text { Blinding (performance bias and detection } \\
\text { bias) } \\
\text { Clinician }\end{array}$ & Low risk & $\begin{array}{l}\text { During treatment neither the physician nor } \\
\text { the participants knew which of the } 2 \text { med- } \\
\text { ications they were using }\end{array}$ \\
\hline $\begin{array}{l}\text { Incomplete outcome data (attrition bias) } \\
\text { All outcomes }\end{array}$ & Unclear risk & $\begin{array}{l}\text { Loss to follow-up: } 40 \text { randomised, } 1 \text { lost as } \\
\text { they did not attend (no reason given). They } \\
\text { were not included in final analysis }\end{array}$ \\
\hline Selective reporting (reporting bias) & Low risk & Symptom and clinical response reported. \\
\hline
\end{tabular}

\section{Eisen 1990}

\begin{tabular}{ll} 
Methods & $\begin{array}{l}\text { Randomised controlled, double-blind study } \\
\text { Setting }\end{array}$ \\
\hline Department of Dermatology, University of Michigan Medical Centre
\end{tabular}


Eisen 1990 (Continued)

- 2 = marked improvement $(50 \%$ to $80 \%)$

- 3 = almost complete or complete improvement ( $81 \%$ to $100 \%)$

3. Not assessed

Assessment points

Side-effects reported

Reported results

Notes
Week $0,2,4,6$, and 8

No adverse side-effects. Transient burning sensation of mucosal surfaces during swishing of medication reported in all participants

No reported results for erosive subgroup of participants as trial included non-erosive OLP

Open phase for 8 weeks: placebo group subsequently received ciclosporin rinse for 8 weeks at end of double-blind phase

\section{Risk of bias}

\begin{tabular}{|c|c|c|}
\hline Bias & Authors' judgement & Support for judgement \\
\hline $\begin{array}{l}\text { Random sequence generation (selection } \\
\text { bias) }\end{array}$ & Low risk & Random number tables. \\
\hline Allocation concealment (selection bias) & Unclear risk & Not specifically stated. \\
\hline $\begin{array}{l}\text { Blinding (performance bias and detection } \\
\text { bias) } \\
\text { Participants }\end{array}$ & Low risk & $\begin{array}{l}\text { During the initial } 8 \text { weeks neither the } \\
\text { physician responsible for evaluating the } \\
\text { participants nor the participants knew } \\
\text { the identity of the medications dispensed, } \\
\text { which were identical in appearance and } \\
\text { taste }\end{array}$ \\
\hline $\begin{array}{l}\text { Blinding (performance bias and detection } \\
\text { bias) } \\
\text { Clinician }\end{array}$ & Low risk & $\begin{array}{l}\text { During the initial } 8 \text { weeks neither the } \\
\text { physician responsible for evaluating the } \\
\text { participants nor the participants knew } \\
\text { the identity of the medications dispensed, } \\
\text { which were identical in appearance and } \\
\text { taste }\end{array}$ \\
\hline $\begin{array}{l}\text { Incomplete outcome data (attrition bias) } \\
\text { All outcomes }\end{array}$ & Low risk & No losses to follow-up. \\
\hline Selective reporting (reporting bias) & Low risk & $\begin{array}{l}\text { Mean symptom and clinical scores reported } \\
\text { at baseline and end of therapy (week } 8 \text { ) } \\
\text { Global scores - } 1 \text { to } 3 \text { reported individ- } \\
\text { ually for erythema, erosions, reticulation, } \\
\text { and symptoms at week } 8\end{array}$ \\
\hline
\end{tabular}




\begin{tabular}{|c|c|}
\hline Methods & $\begin{array}{l}\text { Randomised cross-over study } \\
\text { Author contacted on } 1 \text { February } 2010 \text { to confirm cross-over was performed and results } \\
\text { reported } \\
\text { Setting } \\
\text { Eastman Dental Institute for Oral Health Care Sciences, University of London }\end{array}$ \\
\hline Participants & $\begin{array}{l}\text { Inclusion criteria of the trial } \\
\text { Histological diagnosis and symptomatic erosive/ulcerative LP } \\
\text { Total } n=44\end{array}$ \\
\hline Interventions & $\begin{array}{l}\text { Sequence 1: } \\
\text { A: Fluticasone propionate (FP) spray } 50 \mathrm{mcg} 2 \text { puffs - QDS }(\mathrm{n}=22) \\
\text { B: Betamethasone sodium phosphate (BSP) mouthwash } 500 \mathrm{mcg} \text { - QDS }(\mathrm{n}=22) \\
\text { Applied for } 6 \text { weeks } \\
\text { Sequence 2: } \\
\text { Followed by 2-week wash-out then cross-over }\end{array}$ \\
\hline Outcomes & 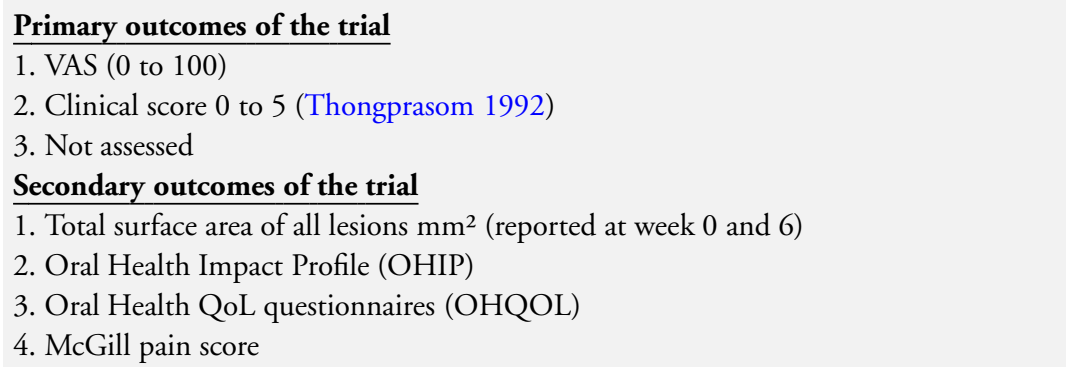 \\
\hline
\end{tabular}
difficulty in spray application (7), dry mouth (2), sore throat (1), red and painful tongue (1), and pseudomembranous candidiasis (1)

Betamethasone mouthwash: none reported

Reported results

Change at week 6 from baseline significant for both groups. No significant difference between the 2 groups in decreasing VAS or QOL. FP significantly better than BSP in decreasing surface area of lesions

Notes

\section{Risk of bias}

Bias Authors' judgement

Random sequence generation (selection Low risk bias)

\section{Support for judgement}

Table of randomised numbers. 


\section{Hegarty 2002 (Continued)}

\begin{tabular}{|c|c|c|}
\hline Allocation concealment (selection bias) & Unclear risk & $\begin{array}{l}\text { A dedicated nurse, who also administered } \\
\text { the participant assessment questionnaires, } \\
\text { undertook the randomisation and assign- } \\
\text { ment. The sequence was concealed until } \\
\text { the effect of both interventions was anal- } \\
\text { ysed }\end{array}$ \\
\hline
\end{tabular}

Blinding (performance bias and detection High risk

Different delivery systems.

bias)

Participants

Blinding (performance bias and detection Low risk bias)

The examining physician was blinded to

the medication sequence

Clinician

Incomplete outcome data (attrition bias) Low risk

All outcomes

No losses to follow-up.

Selective reporting (reporting bias)

High risk

All outcomes reported except Primary 2

(Thongprasom results)

Lin 2005

Methods

Randomised controlled trial

Setting

Department of Periodontal Disease, Hospital of Stomatology, Shandong University, Jinan

Inclusion criteria of the trial
$\begin{aligned} & \text { "Peridontal diseases" diagnostic standard on histology erosive oral lichen planus } \\ & \text { Total } \mathrm{n}=94 \\ & \text { Grade I: erosive and ulcerative lesions (TGT: } \mathrm{n}=21, \text { THT: } \mathrm{n}=21) \\ & \text { Grade II: erosive lesions only (TGT: } \mathrm{n}=26, \text { THT } \mathrm{n}=26)\end{aligned}$

Interventions

A: Radix tripterygium hypoglaucum tablets (THT) - 5 tablets TDS

B: Tripterygium glycosides tablets (TGT) -1.0 to $1.5 \mathrm{mg} / \mathrm{kg}$ TDS

Applied for 3 months

Taper dose after 2 to 4 weeks

Outcomes

Primary outcomes of the trial

1. Not assessed

2. Reduction in clinical severity, defined as remarkably effective, effective, or ineffective:

- Remarkably effective = erosive lesions cured completely, showing the same colour as that of the tissues around, with or without whitish mesh

- Effective = erosive lesions cured with "partially remained flush of membrane and colour of white mesh turning to light"

- Ineffective = erosions and congestions remaining

3. Not assessed 


\section{Lin 2005 (Continued)}

\begin{tabular}{|c|c|c|}
\hline Assessment points & \multicolumn{2}{|c|}{ Baseline and at end of 3 months } \\
\hline Side-effects reported & \multicolumn{2}{|c|}{ TGT: Menstrual disturbance (6) and leucopenia (1) } \\
\hline Reported results & \multicolumn{2}{|c|}{ TGT superior to THT in reducing clinical severity $(P=0.043)$, but more side-effects } \\
\hline Notes & \multicolumn{2}{|l|}{-} \\
\hline \multicolumn{3}{|l|}{ Risk of bias } \\
\hline Bias & Authors' judgement & Support for judgement \\
\hline $\begin{array}{l}\text { Random sequence generation (selection } \\
\text { bias) }\end{array}$ & Low risk & Number table. \\
\hline Allocation concealment (selection bias) & Unclear risk & Not specifically stated. \\
\hline $\begin{array}{l}\text { Blinding (performance bias and detection } \\
\text { bias) } \\
\text { Participants }\end{array}$ & Unclear risk & Not specifically stated. \\
\hline $\begin{array}{l}\text { Blinding (performance bias and detection } \\
\text { bias) } \\
\text { Clinician }\end{array}$ & Unclear risk & Not specifically stated. \\
\hline $\begin{array}{l}\text { Incomplete outcome data (attrition bias) } \\
\text { All outcomes }\end{array}$ & Low risk & No losses to follow-up. \\
\hline Selective reporting (reporting bias) & Low risk & All outcomes reported. \\
\hline
\end{tabular}

Malhotra 2008

\begin{tabular}{|c|c|}
\hline Methods & $\begin{array}{l}\text { Randomised comparative study } \\
\text { Author contacted (binodkhaitan@hotmail.com) - replied with breakdown } \\
\text { Setting } \\
\text { Department of Dermatology and Venereology, All India Institute of Medical Sciences }\end{array}$ \\
\hline Participants & $\begin{array}{l}\text { Inclusion criteria of the trial } \\
\text { Clinical OLP. Total } \mathrm{n} \text { randomised }=49 \text { (group A [mini-pulse therapy] }-\mathrm{n}=25 \text {, group B } \\
\text { [topical triamcinolone acetonide] }-\mathrm{n}=24 \text { ) } \\
\text { No histology } \\
\text { Erosive subgroup: total } \mathrm{n}=22 \text { (group } \mathrm{A}-\mathrm{n}=15 \text {, group } \mathrm{B}-\mathrm{n}=7 \text { ) } \\
11 \text { out of } 15 \text { in group } \mathrm{A} \text { and } 5 \text { out of } 7 \text { in group B who had erosions completed the } \\
\text { follow-up period }\end{array}$ \\
\hline Interventions & $\begin{array}{l}\text { A: Betamethasone oral mini-pulse therapy - } 5 \mathrm{mg} 2 \text { consecutive days/week } \\
\text { B: Topical triamcinolone acetonide }(0.1 \%) \text { paste - TDS } \\
\text { Applied for } 6 \text { months - above doses for } 3 \text { months, then taper dose }\end{array}$ \\
\hline
\end{tabular}




\begin{tabular}{|c|c|}
\hline Outcomes & $\begin{array}{l}\text { Primary outcomes of the trial } \\
\text { 1. Not assessed } \\
\text { 2. Mean severity scores (Score of } 0 \text { to } 12 \text { on a clinical scoring system where the extent } \\
\text { of involvement of the buccal mucosa, tongue, lips, gingiva, and palate are scored and } \\
\text { added up to a maximum of } 12 \text { points) } \\
\text { - Grade } 0=0 \text { points } \\
\text { - Grade I }=1 \text { to } 3 \text { points } \\
\text { - Grade II = } 4 \text { to } 6 \text { points } \\
\text { - Grade III = } 7 \text { to } 12 \text { points } \\
\text { Reported as mean severity score at baseline and subsequent follow-ups for both groups } \\
\text { 3. Not assessed } \\
\text { Outcomes not prespecified in the protocol } \\
\text { - Subjective response was considered only if the participant achieved asymptomatic } \\
\text { state. Changes in symptoms evaluated on a scale of } 0 \% \text { to } 100 \% \text {, with } 10 \% \text { as a unit. } \\
\text { (Emailed author again for breakdown } 19 \text { February } 2010 \text { - no response) }\end{array}$ \\
\hline
\end{tabular}

Week $0,2,4,8,16,20$, and 24

Side-effects reported

Betamethasone: oedema over face (transient) (7), oedema over hands and feet (4), epigastric discomfort (7), weakness/fatigue (5), loose stools (1), headache (1), diabetes mellitus (1), weight gain (1), and dry mouth (1)

Triamcinolone: epigastric discomfort (1) and candidiasis (5)

Reported results

No reported results for erosive subgroup of participants as trial included non-erosive OLP. Breakdown of mean severity scores for erosive subgroup obtained from authors via email

Notes -

\section{Risk of bias}

Bias Authors' judgement

Support for judgement

Random sequence generation (selection Low risk bias)

Allocation concealment (selection bias) Unclear risk

Blinding (performance bias and detection High risk bias)

Participants

Blinding (performance bias and detection Unclear risk bias)

Clinician
Random number table.

Sealed envelope method (unclear if sequentially numbered and opaque)

Different delivery systems. Quote: "Limitations: The study was not blinded..." 
Malhotra 2008 (Continued)

\begin{tabular}{|c|c|c|}
\hline $\begin{array}{l}\text { Incomplete outcome data (attrition bias) } \\
\text { All outcomes }\end{array}$ & High risk & $\begin{array}{l}3 \text { losses to follow-up ( } 2 \text { from group A and } \\
1 \text { from group B) were not included in final } \\
\text { analysis. No ITT }\end{array}$ \\
\hline
\end{tabular}

$\begin{array}{lll}\text { Selective reporting (reporting bias) } & \text { Low risk } & \text { All outcomes reported. }\end{array}$

Passeron 2007

Methods

Randomised, double-blind, prospective trial

Setting

Department of Dermatology, University Hospital of Nice

Participants

Inclusion criteria of the trial

Histological diagnosis of erosive oral lichen planus, must have had at least 1 other treatment, $>25 \%$ mucosal involvement grade 4 (duration not stated)

Total $n=12(1 \%$ pimecrolimus cream $-n=6$, vehicle $-n=6)$

$\begin{array}{ll}\text { Interventions } & \text { A: } 1 \% \text { pimecrolimus cream } \\ \text { B: Vehicle (placebo) } \\ \text { Applied twice daily for } 4 \text { weeks }\end{array}$

Outcomes

Primary outcomes of the trial

1. Spontaneous and meal-triggered pain (scored 0 to 4 on a VAS)

2. Surface area involved (\% involvement on ordinal scale 1 to 4 )

- $1=<5 \%$ involvement

- $2=5 \%$ to $15 \%$ involvement

- $3=16 \%$ to $25 \%$ involvement

- $4=>25 \%$ involvement

The sum of all 3 scores for spontaneous pain, meal-triggered pain, and surface area involved gave a maximum score of 12

3. Subjective participant assessment at end of study (questionnaire - score as follows: worse, no effect, or mild; moderate; or important improvement)

Secondary outcomes of the trial

1. Pimcrolimus level in blood, blood pressure, blood laboratory investigations, and adverse events

Assessment points Week 0,4 , and 8

Side-effects reported

Pimecrolimus well-tolerated, transient burning (2) during first 2 weeks

Reported results

1\% Pimecrolimus cream effective compared with placebo. Well-tolerated

All participants in the pimecrolimus group whose condition improved had a relapse within the month following the end of treatment

Notes

Hard to blind a trial when participants are aware of side-effects of burning with active agent

Interventions for erosive lichen planus affecting mucosal sites (Review) 
Passeron 2007 (Continued)

\section{Risk of bias}

\begin{tabular}{|c|c|c|}
\hline Bias & Authors' judgement & Support for judgement \\
\hline $\begin{array}{l}\text { Random sequence generation (selection } \\
\text { bias) }\end{array}$ & Low risk & $\begin{array}{l}\text { Draw lots, with equilibration every } 4 \text { sub- } \\
\text { jects. }\end{array}$ \\
\hline Allocation concealment (selection bias) & Unclear risk & Not specifically stated in paper. \\
\hline $\begin{array}{l}\text { Blinding (performance bias and detection } \\
\text { bias) } \\
\text { Participants }\end{array}$ & Unclear risk & $\begin{array}{l}\text { Stated as "double-blind" in title, abstract, } \\
\text { and methods. }\end{array}$ \\
\hline
\end{tabular}

Blinding (performance bias and detection Unclear risk bias)

Stated as "double-blind" in title, abstract,

Clinician

\begin{tabular}{lll}
\hline Incomplete outcome data (attrition bias) & Low risk & All included in analysis. ITT.
\end{tabular}

All outcomes

\begin{tabular}{lll}
\hline Selective reporting (reporting bias) & Low risk & All outcomes reported. \\
\hline
\end{tabular}

Radfar 2008

\begin{tabular}{|c|c|}
\hline Methods & $\begin{array}{l}\text { Randomised, comparative, double-blind study } \\
\text { Setting } \\
\text { Oral Medicine Clinic at the School of Dental Medicine, State University of New York } \\
\text { at Buffalo }\end{array}$ \\
\hline Participants & $\begin{array}{l}\text { Inclusion criteria of the trial } \\
\text { Histological diagnosis of OLP and clinically symptomatic oral lesions. All participants } \\
\text { had erosive/ulcerative LP. Oral lesions } 10 \mathrm{~mm} \text { or more } \\
\text { Total } \mathrm{n}=29 \text { (tacrolimus }-\mathrm{n}=15 \text {, clobetasol }-\mathrm{n}=14)\end{array}$ \\
\hline Interventions & $\begin{array}{l}\text { A: Topical tacrolimus } 0.1 \% \text { ointment } \\
\text { B: Clobetasol propionate } 0.05 \% \text { ointment } \\
\text { Applied for } 6 \text { weeks (QDS } 2 \text { weeks, TDS } 2 \text { weeks, BD } 1 \text { week, OD } 1 \text { week) and nystatin } \\
\text { oral rinse once daily in both groups }\end{array}$ \\
\hline Outcomes & $\begin{array}{l}\text { Primary outcomes of the trial } \\
\text { 1. Symptomatology score VAS } 0 \text { to } 10 \\
\text { - Complete response = VAS } 0 \text { (absence of any discomfort) } \\
\text { - Partial response = decrease in VAS } \\
\text { - Worsening = increase in VAS } \\
\text { - Persistence = no change in VAS } \\
\text { 2. Not assessed } \\
\text { 3. Not assessed } \\
\text { Secondary outcomes of the trial }\end{array}$ \\
\hline
\end{tabular}




\begin{tabular}{|c|c|c|}
\hline & \multicolumn{2}{|c|}{$\begin{array}{l}\text { 1. Measurement of target lesion size (longest dimension, picture taken with ruler in } \\
\text { place) } \\
\text { Complete response (disappearance of lesions) }=1 \text {. Scores were either } 0 \text { or } 1 \\
\text { 2. Telephone interview } 9 \text { months after completion of treatment about their lesion-free } \\
\text { period after completion of study }\end{array}$} \\
\hline Assessment points & \multicolumn{2}{|l|}{ Week 0,2 , and 6} \\
\hline Side-effects reported & \multicolumn{2}{|c|}{ Burning sensation with topical tacrolimus } \\
\hline Reported results & \multicolumn{2}{|c|}{$\begin{array}{l}\text { Tacrolimus as useful as clobetasol in the treatment of OLP } \\
\text { No significant difference between both groups }\end{array}$} \\
\hline Notes & \multicolumn{2}{|c|}{$\begin{array}{l}\text { Clinical severity was assessed by measuring mean lesion size rather, than a Physician } \\
\text { Global Asessment (using an ordinal scale) }\end{array}$} \\
\hline \multicolumn{3}{|l|}{ Risk of bias } \\
\hline Bias & Authors' judgement & Support for judgement \\
\hline $\begin{array}{l}\text { Random sequence generation (selection } \\
\text { bias) }\end{array}$ & Low risk & $\begin{array}{l}\text { Computer-generated random number ta- } \\
\text { bles. }\end{array}$ \\
\hline Allocation concealment (selection bias) & Low risk & $\begin{array}{l}\text { Ointments were prepackaged by university } \\
\text { pharmacists in identical containers }\end{array}$ \\
\hline $\begin{array}{l}\text { Blinding (performance bias and detection } \\
\text { bias) } \\
\text { Participants }\end{array}$ & Low risk & $\begin{array}{l}\text { Quote: "During treatment, neither the } \\
\text { practitioners nor the participants were } \\
\text { aware of the medications they were using." }\end{array}$ \\
\hline $\begin{array}{l}\text { Blinding (performance bias and detection } \\
\text { bias) } \\
\text { Clinician }\end{array}$ & Low risk & $\begin{array}{l}\text { Quote: "During treatment, neither the } \\
\text { practitioners nor the participants were } \\
\text { aware of the medications they were using." }\end{array}$ \\
\hline $\begin{array}{l}\text { Incomplete outcome data (attrition bias) } \\
\text { All outcomes }\end{array}$ & Low risk & $\begin{array}{l}\text { Quote: "Data from } 29 \text { patients were ana- } \\
\text { lyzed..." } \\
\text { Comment: losses to follow-up: } 29 \text { ran- } \\
\text { domised. } 2 \text { losses (burning sensation, no } \\
\text { reason) }\end{array}$ \\
\hline Selective reporting (reporting bias) & Low risk & Primary and secondary outcomes reported. \\
\hline
\end{tabular}


Methods

$\frac{\text { Setting }}{\text { Department of Oral Pathology and Medicine, University of Milan }}$

Participants

\section{Inclusion criteria of the trial}

WHO criteria symptomatic and previous untreated OLP, histological confirmation (group A - $\mathrm{n}=14$, group B $-\mathrm{n}=11$ )

Erosive/atrophic subtype: group A - $n=6$ (all female), group B - $n=6$ (3 male, 3 female)
A: Clobetasol propionate ointment $0.05 \%$

B: Mesalazine gel $5 \%$ in adhesive base (Topasa gel)

Applied twice daily for 4 weeks on dried lesions

Outcomes

\section{Primary outcomes of the trial}

1. VAS 0 to 10

At 4 weeks:

- Complete response = no symptoms

- Partial response = reduction in VAS

- No response $=$ no change in VAS

2. Not assessed

3. Not assessed

Assessment points Week 0 and 4

Side-effects reported No side-effects

Reported results

No reported results for erosive subgroup of participants as trial included non-erosive OLP. Breakdown of individual VAS for each of the 25 participants at baseline and end of treatment were reported in a table. Hence, data on the erosive subgroup was available

Notes

\section{Risk of bias}

\begin{tabular}{|c|c|c|}
\hline Bias & Authors' judgement & Support for judgement \\
\hline $\begin{array}{l}\text { Random sequence generation (selection } \\
\text { bias) }\end{array}$ & Low risk & Random number tables. \\
\hline Allocation concealment (selection bias) & Unclear risk & Not specifically stated. \\
\hline $\begin{array}{l}\text { Blinding (performance bias and detection } \\
\text { bias) } \\
\text { Participants }\end{array}$ & Low risk & $\begin{array}{l}\text { Quote: “...even though the patients did not } \\
\text { know if the tube they received from the in- } \\
\text { vestigator contained steroid or mesalazine. } \\
\text { " }\end{array}$ \\
\hline
\end{tabular}

Blinding (performance bias and detection Low risk bias)

Clinician
Only VAS assessed, which is participantreported. 
Sardella 1998 (Continued)

\begin{tabular}{l|ll}
\hline $\begin{array}{l}\text { Incomplete outcome data (attrition bias) } \\
\text { All outcomes }\end{array}$ & Low risk & No losses to follow-up. \\
\hline Selective reporting (reporting bias) & Low risk & All outcomes reported. \\
\hline
\end{tabular}

\section{Swift 2005}

\begin{tabular}{|c|c|}
\hline Methods & $\begin{array}{l}\text { Randomised controlled trial } \\
\text { Setting } \\
\text { Stomatology Centre of the Baylor College of Dentistry, Dallas, Texas }\end{array}$ \\
\hline Participants & $\begin{array}{l}\text { Inclusion criteria of the trial } \\
\text { Erosive oral lichen planus clinical and histology } \\
\text { Total } n=20(n=10 \text { in each arm) }\end{array}$ \\
\hline Interventions & $\begin{array}{l}\text { A: } 1 \% \text { pimecrolimus cream } \\
\text { B: Placebo cream BD } \\
\text { Applied for } 4 \text { weeks (similar } 15 \mathrm{~g} \text { tubes with a } 1 \mathrm{ml} \text { measuring device) }\end{array}$ \\
\hline Outcomes & $\begin{array}{l}\text { Primary outcomes of the trial } \\
\text { 1. VAS } 0 \text { to } 100 \\
\text { 2. Clinical severity (area of ulceration }+ \text { area of erythema }+ \text { area of reticulation in } \mathrm{mm}^{2} \\
=\text { weighted sum) } \\
\text { 3. Not assessed } \\
\text { Outcomes not prespecified in the protocol } \\
\text { - Laboratory studies (complete blood count, complete metabolic panel) }\end{array}$ \\
\hline Assessment points & Week 0,2 , and 4 \\
\hline Side-effects reported & $\begin{array}{l}\text { Pimecrolimus: slight burning tip of tongue after applying } 1 \% \text { pimecrolimus on gingiva } \\
\text { lesions, but resolved within minutes }\end{array}$ \\
\hline Reported results & Significant reduction in VAS $(\mathrm{P}=0.022)$ in treatment group, but not lesion size \\
\hline Notes & $\begin{array}{l}\text { Hard to blind a trial when participants are aware of the side-effects of burning with active } \\
\text { agent }\end{array}$ \\
\hline
\end{tabular}

\section{Risk of bias}

\begin{tabular}{lll}
\hline Bias & Authors' judgement & Support for judgement \\
\hline $\begin{array}{l}\text { Random sequence generation (selection } \\
\text { bias) }\end{array}$ & Low risk & $\begin{array}{l}\text { Computer-generated table of random } \\
\text { numbers (clarified with authors via email } \\
\text { trees@bcd.tamhsc.edu) }\end{array}$ \\
\hline Allocation concealment (selection bias) & Low risk & $\begin{array}{l}\text { Allocation concealment achieved by using a } \\
\text { placebo cream that was prepared by a phar- }\end{array}$
\end{tabular}


Swift 2005 (Continued)

\begin{tabular}{|l|l} 
macist and dispensed in a 15 gram tube \\
similar to the tube containing the pime- \\
crolimus. The tubes were unlabeled. Par- \\
ticipants in both groups received the same \\
$1 \mathrm{ml}$ measuring device and instructions to \\
use $1 / 4$ to $1 / 2$ of the $1 \mathrm{ml}$ scoop of medication \\
per application
\end{tabular}

Blinding (performance bias and detection Low risk bias)

Participants
Quote: "Both the participants and the examiner were masked to the type of medication dispensed."
Blinding (performance bias and detection Low risk bias)

Clinician

Incomplete outcome data (attrition bias) Low risk All outcomes
Quote: "Both the participants and the examiner were masked to the type of medication dispensed."

Quote: "When the two participants dropped out relatively early in the project patients who met the study criteria received blood tests as required. The first candidate who met all inclusion criteria was assigned the number of the first individual who was dropped. The same approach was taken for the second candidate who was assigned the number and appropriate arm of the second patient who was dropped. Both participants were managed identically to other study participants and the principal investigator was blinded at all times."

Losses to follow-up: 2 losses early on, but replaced by other participants who were given the original group assignment (clarified with authors via email trees@bcd. tamhsc.edu)

Selective reporting (reporting bias)

Low risk

All outcomes reported.

Volz 2008

Methods

Participants
Randomised controlled trial

Setting

Department of Dermatology, University Hospital of Tubingen, Germany

\section{Inclusion criteria of the trial}

Clinical and histological diagnosis of erosive oral LP

Total $\mathrm{n}=20$ (15 women, 5 men, $\mathrm{n}=10$ in each group) 


\begin{tabular}{ll}
\hline Interventions & $\begin{array}{l}\text { A: } 1 \% \text { pimecrolimus cream } \\
\text { B: Placebo }\end{array}$ \\
\hline Outcomes & $\begin{array}{l}\text { Primary outcomes of the trial } \\
\text { 1. Spontaneous and food-triggered pain (VAS } 0 \text { to } 10)\end{array}$ \\
$\begin{array}{l}\text { 2a. Erosive surface area on an ordinal scale of } 1 \text { to } 4(<5 \% \text { involvement }=1,5 \% \text { to } 15 \% \\
=2,>15 \% \text { to } 25 \%=3,>25 \%=4)\end{array}$ \\
$\begin{array}{l}\text { 2b. Investigator Global Assessment } \\
\text { IGA on a 5-point scale was determined at day } 30 \text { by qualifying the overall status of the oral } \\
\text { mucosa in comparison with baseline (worsening, no improvement, slight improvement, } \\
\text { medium improvement, and strong improvement) } \\
\text { Reported data as composite scores of VAS and erosive surface areas. This composite score } \\
\text { was the primary efficacy variable of the study. The author was contacted on } 7 \text { September } \\
\text { 2009 and } 4 \text { October } 2009 \text { for breakdown of scores for VAS, but no response received } \\
\text { (tilo.biedermann@med.uni-tuebingen.de) } \\
\text { 3. Not assessed }\end{array}$ \\
\hline
\end{tabular}

Assessment points

Side-effects reported

Reported results
Day 0,30 , and 60

Pimecrolimus: burning sensation (4) and mucosal paraesthesia (1)

Placebo: burning sensation (1) and mucosal paraesthesia (1)

Significant reduction in clinical severity $(\mathrm{P}=0.032)$ in treatment group as detected by Investigator's Global Assessment

Notes

Hard to blind a trial when participants are aware of side-effects of burning with active agent

\section{Risk of bias}

\begin{tabular}{|c|c|c|}
\hline Bias & Authors' judgement & Support for judgement \\
\hline $\begin{array}{l}\text { Random sequence generation (selection } \\
\text { bias) }\end{array}$ & Low risk & $\begin{array}{l}\text { Validated system that automated the ran- } \\
\text { dom assignment of treatment groups to } \\
\text { randomisation numbers }\end{array}$ \\
\hline Allocation concealment (selection bias) & Low risk & $\begin{array}{l}\text { Quote: "Study medication was prepared } \\
\text { and packaged by Novartis Pharma in iden- } \\
\text { tical tubes differing only in the randomisa- } \\
\text { tion numbers. Until unblinding, randomi- } \\
\text { sation data were kept strictly confidential." }\end{array}$ \\
\hline $\begin{array}{l}\text { Blinding (performance bias and detection } \\
\text { bias) } \\
\text { Participants }\end{array}$ & Low risk & $\begin{array}{l}\text { Quote: "All personnel directly involved in } \\
\text { the conduct of the study remained blinded } \\
\text { to the treatment assignment until all pa- } \\
\text { tients had completed the study and all data } \\
\text { had been retrieved for finalised analysis." }\end{array}$ \\
\hline
\end{tabular}


Blinding (performance bias and detection Low risk bias)

Clinician
Quote: "All personnel directly involved in the conduct of the study remained blinded to the treatment assignment until all patients had completed the study and all data had been retrieved for finalised analysis."

Quote: "Primary analyses were performed on the ITT population using the last observation carried forward method for missing data."

Incomplete outcome data (attrition bias) Low risk All outcomes

Selective reporting (reporting bias) $\quad$ Low risk All outcomes reported.

Voute 1993

Methods

Randomised, double-blind, placebo-controlled clinical study

Setting

Department of Oral and Maxillofacial SUrgery and Oral Pathology, Free University Hospital, Amsterdam

Participants

Inclusion criteria of the trial

History, clinical diagnosis, histology, immunofluorescence consistent with OLP

Total $n=40$

Erosive type - 2 men, 10 women. Active group = erosive 5, combination $9=14$ total; placebo group $=$ erosive 7 , combination $6=13$ total

Interventions

A: Fluicinomide ointment

B: Placebo (adhesive ointment base: $40 \%$ hypromellose in white soft paraffin)

Applied to dried lesions at least 6 times per day for 9 weeks

Outcomes

\section{Primary outcomes of the trial}

1. VAS (scale not stated)

No breakdown of VAS for erosive subtype

2. Clinical severity (objective score) measured by comparing clinical photographs. Breakdown of erosive subtype results available

Symptom and clinical response reported at week 9 . These were subdivided into 5 groups:

- $0 \%=$ no response

- $<33 \%$ = partial

- $<66 \%$ = good

- $100 \%=$ complete remission

- Increase signs

3. Not assessed

Assessment points

Week 0, 3, and 9. Follow-up for 3 to 17 months after end of treatment

Side-effects reported

No side-effects during study and follow-up period

Reported results

Results for erosive subgroup not reported as trial included non-erosive OLP 
Voute 1993 (Continued)

\begin{tabular}{|c|c|c|}
\hline Notes & - & \\
\hline \multicolumn{3}{|l|}{ Risk of bias } \\
\hline Bias & Authors' judgement & Support for judgement \\
\hline $\begin{array}{l}\text { Random sequence generation (selection } \\
\text { bias) }\end{array}$ & Unclear risk & Stated as randomised. \\
\hline Allocation concealment (selection bias) & Low risk & $\begin{array}{l}\text { Both the active medication and placebo } \\
\text { ointment were extemporaneously mixed in } \\
\text { the Department of Pharmacy of the Free } \\
\text { University Hospital, Amsterdam }\end{array}$ \\
\hline $\begin{array}{l}\text { Blinding (performance bias and detection } \\
\text { bias) } \\
\text { Participants }\end{array}$ & Unclear risk & Stated as double-blind. Base is non-tasting. \\
\hline $\begin{array}{l}\text { Blinding (performance bias and detection } \\
\text { bias) } \\
\text { Clinician }\end{array}$ & Unclear risk & Stated as double-blind. \\
\hline $\begin{array}{l}\text { Incomplete outcome data (attrition bias) } \\
\text { All outcomes }\end{array}$ & Low risk & No losses to follow-up. \\
\hline Selective reporting (reporting bias) & Low risk & Symptom and clinical responses reported. \\
\hline
\end{tabular}

Yoke 2006

\begin{tabular}{|c|c|}
\hline Methods & $\begin{array}{l}\text { Randomised controlled trial } \\
\text { Author contacted (pcy@ndc.com.sg) - replied with breakdown of erosive subtype } \\
\text { Setting } \\
\text { Multicentre (hospital) (Singapore, India, South Korea, Thailand) }\end{array}$ \\
\hline Participants & $\begin{array}{l}\text { Inclusion criteria of the trial } \\
\text { Clinical signs and symptoms, histologically confirmed OLP. } \mathrm{N} \text { randomised }=139 \\
\text { Erosive subtype: total } \mathrm{n}=15 \text { (group A (triamcinolone acetonide) - } \mathrm{n}=4 \text { (outcome data } \\
\text { for } 2 \text { out of } 4 \text { ), group B (ciclosporin solution) - } \mathrm{n}=11 \text { (outcome data for } 9 \text { out of } 11 \text { ) }\end{array}$ \\
\hline Interventions & $\begin{array}{l}\text { A: Triamcinolone acetonide in orabase TDS } \\
\text { B: Ciclosporin solution TDS } \\
\text { Appplied for } 8 \text { weeks }\end{array}$ \\
\hline Outcomes & $\begin{array}{l}\text { Primary outcomes of the trial } \\
\text { 1. VAS } 0 \text { to } 100 \text { for pain, VAS } 0 \text { to } 100 \text { for burning sensation } \\
\text { 2. Clinical score } 0 \text { to } 5 \text { (most severe and extensive marker lesion) (Thongprasom 1992) } \\
\text { Clinical response defined as a reduction in clinical score from baseline of at least } 1 \text { unit } \\
\text { at } 4 \text { weeks after randomisation }\end{array}$ \\
\hline
\end{tabular}


Yoke 2006 (Continued)

\section{Not assessed}

\section{Secondary outcomes of the trial}

1. and 2. Marker lesion size measured by a transparent grid calibrated to $2 \mathrm{~mm}$ squares

\begin{tabular}{ll} 
Assessment points & Week 0, 2, 4, 6, and 8 \\
\hline Side-effects reported & $\begin{array}{l}\text { No significant adverse events. Transient burning sensation upon initial application with } \\
\text { both treatments }\end{array}$ \\
\hline Reported results & $\begin{array}{l}\text { No reported results for erosive subgroup of participants as trial included non-erosive } \\
\text { OLP }\end{array}$ \\
\hline Notes & - \\
\hline
\end{tabular}

Risk of bias

\begin{tabular}{|c|c|c|}
\hline Bias & Authors' judgement & Support for judgement \\
\hline $\begin{array}{l}\text { Random sequence generation (selection } \\
\text { bias) }\end{array}$ & Unclear risk & $\begin{array}{l}\text { Stated as "randomly assigned", but no spe- } \\
\text { cific details on randomisation stated }\end{array}$ \\
\hline Allocation concealment (selection bias) & Low risk & $\begin{array}{l}\text { Central randomisation office of Clinical } \\
\text { Trials and Epidemiology Research Unit via } \\
\text { telephone (Singapore and South Korea)/ } \\
\text { sealed envelope (India and Thailand) - not } \\
\text { stated if opaque }\end{array}$ \\
\hline $\begin{array}{l}\text { Blinding (performance bias and detection } \\
\text { bias) } \\
\text { Participants }\end{array}$ & High risk & Different delivery systems. \\
\hline $\begin{array}{l}\text { Blinding (performance bias and detection } \\
\text { bias) } \\
\text { Clinician }\end{array}$ & Unclear risk & Not specifically stated. \\
\hline $\begin{array}{l}\text { Incomplete outcome data (attrition bias) } \\
\text { All outcomes }\end{array}$ & Low risk & $\begin{array}{l}12 \text { losses to follow-up and } 11 \text { discontinued } \\
\text { drug, all } 139 \text { randomised participants in- } \\
\text { cluded in final analysis } \\
\text { (Breakdown of data for erosive subgroup: } \\
\text { incomplete outcome data for } 4 \text { out of } 15 \\
\text { erosive subgroup participants.) }\end{array}$ \\
\hline Selective reporting (reporting bias) & Low risk & $\begin{array}{l}\text { All outcomes reported (stated under "out- } \\
\text { comes" that clinical response will be re- } \\
\text { ported, but not clinical score) }\end{array}$ \\
\hline
\end{tabular}

$\mathrm{n}=$ number

$\mathrm{OD}=$ once daily 
$\mathrm{BD}=$ twice daily

TDS = three times per day

QDS = four times per day

\section{Characteristics of excluded studies [ordered by study ID]}

\begin{tabular}{|c|c|}
\hline Study & Reason for exclusion \\
\hline Bouloc 2000 & $\begin{array}{l}\text { Not ELP. Vignette. Compared a new vitamin D3 analogue (KH1060) with the vehicle in the treatment of } \\
\text { cutaneous lichen planus. One of the exclusion criteria was exclusive presence of actinic, atrophic, or bullous } \\
\text { variations of LP. Results table/graph not reported. Supported by Leo Pharmaceuticals Products }\end{array}$ \\
\hline Buajeeb 1997 & $\begin{array}{l}\text { Not a RCT. Stated "randomly assigned" in abstract, but under study design stated "patients were alternately } \\
\text { given A or B as they presented to the clinic for treatment." }\end{array}$ \\
\hline Buajeeb 2000 & Not a RCT. \\
\hline Carbone 2003 & Not a RCT. \\
\hline Chainani-Wu 2007 & $\begin{array}{l}\text { The reason for exclusion is that this phase II RCT evaluated the efficacy and safety of curcuminoids as an } \\
\text { adjunct to short-course corticosteroids } \\
\text { Compared curcuminoids (standardised extract of tumeric rhizomes cultivated in India) } 2000 \mathrm{mg} / \text { day versus } \\
\text { (vs) placebo for } 7 \text { weeks + oral prednisolone } 60 \mathrm{mg} \text { for the first week in both arms } \\
\text { Trial ended early for futility. The first interim analysis (using data from the first } 33 \text { subjects) did not show a } \\
\text { significant difference between the } 2 \text { groups. Conditional power calculations suggested a less than } 2 \% \text { chance } \\
\text { that the curcuminoids group would have a significantly better outcome compared with placebo if the trial } \\
\text { were continued to completion. Target number was } 100 \text { participants }\end{array}$ \\
\hline Chang 2008 & Case series, not a RCT. 5 out of 7 had vulval ELP. \\
\hline Corrocher 2008 & Oral lichen planus, not erosive. \\
\hline Gaeta 1994 & Not a RCT. No data for placebo arm. Outcome measures not properly defined \\
\hline Gorouhi 2007 & $\begin{array}{l}\text { Author contacted (firozali@sina.tums.ac.ir) 4 October } 2009 \text { and } 14 \text { December } 2009 \text { - no response. Only } 27 / \\
40 \text { had ELP. No breakdown of results for ELP subgroup }\end{array}$ \\
\hline Goulet 2001 & Oral LP, not erosive. Pilot RCT. No sufficient data. Abstract \\
\hline Hersle 1982 & Oral lichen planus. Split erosive/non-erosive data combined in report, cannot extrapolate \\
\hline Kellett 1990 & Cutaneous, not erosive, LP. \\
\hline Laeijendecker 2006 & $\begin{array}{l}\text { Author contacted (R.Laeijendecker@asz.nl) } 14 \text { December } 2009 \text { - no reply. OLP. 29/40 had erosive subtype. } \\
\text { Breakdown of results was not available; hence, the study was excluded }\end{array}$ \\
\hline Lehman 2009 & Review paper. \\
\hline
\end{tabular}


(Continued)

\begin{tabular}{ll}
\hline Lener 2001 & Case report (no abstract in search). \\
\hline Lo Muzio 2001 & $\begin{array}{l}\text { Not all ELP. Recruited } 54 \text { participants with a history of vesiculo-ulcero-erosive oral lesions, of which } 30 \text { had } \\
\text { recurrent oral aphthous ulcers. Only } 24 \text { had oral ELP. } 3 \text { groups compared clobetasol } 0.05 \% \text { vs clobetasol } \\
\text { ointment } 0.05 \% \text { bioadhesive denture paste vs clobetasol } 0.05 \% \text { in orabase. } 8 \text { participants out of } 18 \text { with oral } \\
\text { lichen planus per group (remaining } 10 \text { had aphthous ulceration). Comparing } 3 \text { different groups of } 18 \text { and } \\
\text { comparing different vehicles. No placebo. Assuming product works. States trial is double-blind, but this is not } \\
\text { possible with the different vehicles used }\end{array}$ \\
\hline
\end{tabular}

Lozada-Nur 1994 Participants have vesiculobullous disease - LP. Benign mucous membrane pemphigoid, pemphigus vulgaris, erythema multiforme

Lozada-Nur 2006 Open trial. Not a RCT.

Ma 2004 Not a RCT. Abstract states "random”, but text states "patients were alternately allocated into two groups". (Mandarin - translated.)

Mansourian 2008 Asymptomatic participants with OLP only were included in study

Mousavi $2009 \quad$ Investigated the use of ignatia, a homeopathic remedy for hysteria

Participants were required to have the "mind and general symptom of Ignatia".

Quote: "General symptoms of Ignatia include: a marked hyperesthesia of all the senses, and a tendency to clonic spasms. Mentally, the emotional element is uppermost and co-ordination of function interfered with. ..It is especially adapted to the nervous temperament - women of sensitive, easily excited nature, dark, mild disposition, quick to perceive, rapid in execution. Rapid change of mental and physical conditions is opposite to each other...”

"Mental symptoms include: 'changeable mood; introspective; silently brooding. Melancholic, sad, tearful. Not communicative. Sighing and sobbing. After shocks, grief, disappointment...”

Nolan 2009 Mixed ulcerative/atrophic lichen planus subtype in majority, erosive/desquamative in 50 out of 124 participants

Piattelli 2007 Only 4/20 of participants had erosive/atrophic lichen planus. Results not reported separately. 1 erosive and 1 atrophic participant in each arm - very small number. Emphasis of paper on apoptotic process

Rajar 2008

Not randomised. No details on randomisation or blinding. Text states that participants were "randomly divided into two groups". Participants not blinded as bases are difference (gel vs liquid paraffin). Author contacted (uzmarajar@yahoo.com) 10 August 2010 and 29 August 2010 for clarification, but no response. Vulval LP. N $=34$. Only $82 \%$ had erosive subtype. Breakdown of results not available; hence, the study was excluded

Rödström 1994 Not randomised. No information on randomisation, allocation concealment, or blinding. States "patients were chosen consecutively from those referred to or attending the Department". Assume $\mathrm{n}=20$ in each arm (not stated)

Baseline demographics and clinical data not published.

Results all expressed as a percentage change from baseline. No raw data published

Scardina 2006 Included participants with dysplasia and commented on whether dysplasia improved after treatment No information on randomisation.

Interventions for erosive lichen planus affecting mucosal sites (Review)

Copyright (๑) 2012 The Cochrane Collaboration. Published by John Wiley \& Sons, Ltd. 
(Continued)

\begin{tabular}{|c|c|}
\hline Scheer 2006 & Case series $n=5$. Not a RCT. \\
\hline Sieg 1995 & Not erosive lichen planus (13 participants with chronic oral lichen planus) \\
\hline Silver 1991 & Not a RCT. \\
\hline Thongprasom 2003 & Not a RCT. \\
\hline Thongprasom 2007 & Oral lichen planus, not erosive. \\
\hline Tyldesley 1977 & $\begin{array}{l}\text { No details on randomisation or allocation concealment. } \\
\text { No VAS. } \\
\text { No details on objective clinical assessment. } \\
\text { Not ITT. } \\
\text { No breakdown of baseline demographics in the } 2 \text { arms. } \\
\mathrm{N}=18 \text { for erosive subtype out of } 23 \text {. }\end{array}$ \\
\hline Ungphaiboon 2005 & $\begin{array}{l}\text { Compares triamcinolone acetonide mouthwash vs paste. No clear randomisation and blinding. Small numbers. } \\
7 / 20 \text { with erosive subtype. Outcome points not well-defined. Clinical response ranges for clinical scores too } \\
\text { wide, especially score } 2 \text { ( } 34 \% \text { to } 99 \% \text { reduction) }\end{array}$ \\
\hline Wei 2003 & Not a RCT. \\
\hline Xia 2006 & Self-controlled trial (split body-part) in ulcerative OLP. Exclusion criteria as per protocol \\
\hline Xu 2002 & Not ELP. No blinding, no allocation concealment. RCT. \\
\hline
\end{tabular}

\section{Characteristics of studies awaiting assessment [ordered by study ID]}

\section{Agha-Hosseini 2010}

\begin{tabular}{|c|c|}
\hline Methods & Randomised double-blind placebo-controlled trial \\
\hline Participants & 37 biopsy-proven symptomatic OLP participants \\
\hline Interventions & $\begin{array}{l}\text { A: Purslane }(\mathrm{n}=20) \\
\text { B: Placebo }(\mathrm{n}=17) \\
\text { For } 3 \text { months }\end{array}$ \\
\hline Outcomes & $\begin{array}{l}\text { Outcomes of the trial } \\
\text { 1. Visual analogue scale (VAS) and clinical improvement including lesion type and size (assessments points = baseline, } \\
\text { after } 2 \text { weeks, and each month for } 6 \text { months) }\end{array}$ \\
\hline Notes & - \\
\hline
\end{tabular}


Cilurzo 2010

\begin{tabular}{|c|c|}
\hline Methods & A double-blind, controlled study \\
\hline Participants & 3 groups of participants $(n=16)$ with OLP \\
\hline Interventions & $\begin{array}{l}\text { A new mucoadhesive prolonged release tablet containing } 24 \text { mug clobetasol-17-propionate }(\mathrm{CP}) \text { suitable for the } \\
\text { management of OLP } \\
3 \text { groups of participants }(\mathrm{n}=16) \text { received applications } 3 \text { times per day over } 4 \text { weeks of the developed clobetasol-17- } \\
\text { propionate }(\mathrm{CP}) \text { tablets } \\
\text { A: Active treatment tablets (group CP-T) } \\
\text { B: Placebo tablets (group CP-P) } \\
\text { C: Commercial CP ointment for cutaneous application }(123 \text { mug/application) extemporary mixed with orabase } \\
\text { (group CP-O) }\end{array}$ \\
\hline Outcomes & $\frac{\text { Outcomes of the trial }}{1 . \text { Pain and ulceration }}$ \\
\hline Notes & - \\
\hline
\end{tabular}

\section{Javadzadeh 2008}

\begin{tabular}{ll}
\hline Methods & Randomised, double-blind clinical trial \\
\hline Participants & 50 participants who matched the inclusion criteria \\
\hline Interventions & $\begin{array}{l}\text { A: Experimental group - } 5 \mathrm{ml} \text { of mouthwash } 4 \text { times per day for } 5 \text { minutes } \\
\text { B: Control group - dexamethasone tablet, nystatin drop, and diphenhydramine syrup }\end{array}$ \\
\hline Outcomes & $\begin{array}{l}\text { Outcomes of the trial } \\
\text { 1. Severity of the lesions and pain (assessment points = initial 1-, 2-, 4-, 8-, and 12-week intervals) }\end{array}$ \\
\hline Notes & -
\end{tabular}

Salazar-Sanchez 2010

\begin{tabular}{|c|c|}
\hline Methods & Randomised, double-blind study \\
\hline Participants & 64 participants with OLP \\
\hline Interventions & $\begin{array}{l}\text { A: Topical application of aloe vera }(\mathrm{AV})(\mathrm{n}=32) \\
\text { B: Placebo }(\mathrm{n}=32) \\
\text { At a dose of } 0.4 \mathrm{ml}(70 \% \text { concentration }) 3 \text { times per day }\end{array}$ \\
\hline Outcomes & $\begin{array}{l}\text { Outcomes of the trial } \\
\text { 1. Pain and quality of life (VAS for rating pain; clinical scale for scoring the lesions, the Oral Health Impact Profile } \\
49 \text { (OHIP-49), and the Hospital Anxiety-Depression (HAD) scale; assessment points after } 6 \text { and } 12 \text { weeks) }\end{array}$ \\
\hline Notes & - \\
\hline
\end{tabular}




\begin{tabular}{ll} 
Methods & Prospective randomised, positive-control, double-blind clinical trial \\
\hline Participants & 69 participants with erosive OLP \\
\hline Interventions & $\begin{array}{l}\text { A: Thalidomide } 1 \% \text { paste }(\mathrm{n}=37) \\
\text { B: Dexamethasone } 0.043 \% \text { paste }(\mathrm{n}=32) \text { for } 1 \text { week } \\
\text { Participants without erosions after initial } 1 \text {-week treatment were followed for recurrence; whereas, those with ongoing } \\
\text { erosions received an additional 3-week treatment }\end{array}$ \\
\hline Outcomes & $\begin{array}{l}\text { Outcomes of the trial } \\
\text { 1. Size of erosive area } \\
\text { 2. Visual analogue scale (VAS) scores } \\
\text { 3. 3-month recurrence rates } \\
\text { 4. Adverse effects at } 1 \text { year }\end{array}$ \\
\hline Notes & - \\
\hline
\end{tabular}

\section{Xiong 2009}

Methods Randomised controlled trial

\section{Participants 56 OLP participants}

Interventions Polysaccharide nucleic acid fraction of bacillus calmette-guerin (BCG-PSN) sieved out from various immunomodulators to evaluate the short-term therapeutic efficacy and clinical safety of intralesional BCG-PSN injection for erosive OLP

A: Intralesional injection of $0.5 \mathrm{ml}$ BCG-PSN every other day $(\mathrm{n}=31)$

B: $10 \mathrm{mg}$ triamcinolone acetonide (TA, a positive-controlled group, $\mathrm{n}=25$ ) every week for 2 weeks

After the cessation of treatment, those cured from erosion were followed up for 3 months

\section{Outcomes Outcomes of the trial}

1. Erosive areas and visual analogue scale (VAS) scores both at the start and the end of the treatment

2. Adverse reactions and the recurrence intervals were also registered

Notes

Characteristics of ongoing studies [ordered by study ID]

\section{NCT00135733}

Trial name or title A Randomized, Double-Blind, Placebo-Controlled Pilot Study of the Efficacy and Safety of Alefacept in the Treatment of Moderate to Severe Erosive Mucosal Lichen Planus

(This study has been terminated. Pharmaceutical sponsor withdrew financial support)

$\begin{array}{ll}\text { Methods } & \text { Allocation: randomised } \\ & \text { End point classification: safety/efficacy study } \\ \text { Intervention model: parallel assignment }\end{array}$


NCT00135733 (Continued)

Masking: double-blind (subject, investigator, outcomes assessor)

Primary purpose: treatment

\begin{tabular}{|c|c|}
\hline Participants & $\begin{array}{l}\text { Inclusion criteria of the trial } \\
\text { - At least } 18 \text { years of age } \\
\text { - Diagnosis of moderate to severe mucosal lichen planus } \\
\text { - No systemic (oral or injectable) treatment of lichen planus for } 4 \text { weeks prior to starting study drug } \\
\text { - Willing to forgo changes in topical treatment (creams) for } 4 \text { weeks before receiving the study drug and } \\
\text { during the course of the study } \\
\text { - Off of topical tacrolimus or pimecrolimus for } 4 \text { weeks prior to starting the study drug } \\
\text { - CD4+ T lymphocyte counts must be above the lower limit of normal laboratory value }\end{array}$ \\
\hline Interventions & Amevive (Alefacept) vs placebo \\
\hline Outcomes & $\begin{array}{l}\text { Primary outcomes of the trial } \\
\text { - Statistically significant changes in pain level } \\
\text { - Statistically significant changes in appearance of lesions (sores) } \\
\text { Secondary outcomes of the trial } \\
\text { - Statistically significant changes in severity of itching } \\
\text { - Statistically significant changes in redness, amount of body surface area involved, number of sores, } \\
\text { and/or depth of involvement } \\
\text { - Statistically significant changes in quality of life }\end{array}$ \\
\hline Starting date & April 2004 - December 2004 \\
\hline Contact information & $\begin{array}{l}\text { Principal Investigator: Alexandra B. Kimball, MD, MPH, CURTIS - Clinical Unit for Research Trials in Skin } \\
\text { at Partners (MGH and BWH) }\end{array}$ \\
\hline Notes & - \\
\hline
\end{tabular}

\section{NCT01061853}

Trial name or title

Efficacy of Topical Rapamycin in The Treatment of Chronic Erosive Oral Lichen Planus. Double Blind Randomised Controlled Trial Rapamycin vs Topical Steroids

\begin{tabular}{l|l} 
Methods & $\begin{array}{l}\text { Allocation: randomised } \\
\text { Intervention model: parallel assignment } \\
\text { Masking: double-blind (subject, investigator) } \\
\text { Primary purpose: treatment }\end{array}$ \\
\hline Participants & $\begin{array}{l}\text { Inclusion criteria of the trial } \\
\text { - } 18 \text { years to } 85 \text { years } \\
\text { - Oral lichen planus } \\
\text { - Oral erosive area more than } 1 \mathrm{~cm}^{2} \\
\text { - Lichen planus pathologically proven }\end{array}$ \\
\hline
\end{tabular}

Interventions

Topical sirolimus and petrolatum in orabase (Rapamune) $1 \mathrm{mg} / \mathrm{ml}$ bid 3 months vs topical betamethasone 0 . 05\% in orabase and Phosal (Diprolene) bid during 3 months 


\section{NCT01061853 (Continued)}

\begin{tabular}{|c|c|}
\hline Outcomes & $\begin{array}{l}\text { Primary outcomes of the trial } \\
\text { - Complete clearing of oral erosive lesions (time frame: } 3 \text { months) } \\
\text { Secondary outcomes of the trial } \\
\text { - Regression of erosive surface area (time frame: } 3 \text { months) }\end{array}$ \\
\hline Starting date & February 2008 (expected completion date February 2013) \\
\hline Contact information & $\begin{array}{l}\text { Loïc Vaillant, MD (+33(0)247479080, vaillant@med.univ-tours.fr); and Brigitte Hüttenberger, MD (+33 } \\
\text { (0)247478347, b.huttenberger@chu-tours.fr) }\end{array}$ \\
\hline Notes & France \\
\hline
\end{tabular}

\section{NCT01282515}

Trial name or title A Study of Topical Hexaminolevulinate (HAL) Photodynamic Therapy (PDT) and a Phase III Comparative Treatment Study of HAL PDT in Female Genital Erosive Lichen Planus (GELP)

\begin{tabular}{|c|c|}
\hline Methods & $\begin{array}{l}\text { Allocation: randomised } \\
\text { End point classification: safety/efficacy study } \\
\text { Intervention model: parallel assignment } \\
\text { Masking: single-blind (investigator) } \\
\text { Primary purpose: treatment }\end{array}$ \\
\hline Participants & $\begin{array}{l}\text { Inclusion criteria of the trial } \\
\text { - } 18 \text { years and older } \\
\text { - Females with symptomatically genital ELP } \\
\text { - Clinically verified by at least one doctor from the Vulva clinic } \\
\text { - Untreated for ELP for at least } 4 \text { weeks }\end{array}$ \\
\hline Interventions & Hexaminolevulinate one PDT treatment vs continuous clobetasol propionate \\
\hline Outcomes & $\begin{array}{l}\text { Primary outcomes of the trial } \\
\text { - Percentage change of GELP score and/or VAS score } 6 \text { weeks after start of treatment (time frame: } 6 \\
\text { weeks) } \\
\text { Secondary outcomes of the trial } \\
\text { - Percentage change of GELP score and/or VAS score } 6 \text { months after start of treatment (time frame: } 6 \\
\text { months) } \\
\text { Estimated enrolment: } 48\end{array}$ \\
\hline Starting date & August 2011 (expected completion date June 2012) \\
\hline Contact information & $\begin{array}{l}\text { Anne Lise Helgesen, Candidate of Medicine (0047 98634403, anneliseord@yahoo.no); Trond Warloe, Doctor } \\
\text { Medicinae (trond.warloe@radiumhospitalet.no) }\end{array}$ \\
\hline Notes & Rikshospitalet, Oslo University hospital \\
\hline
\end{tabular}


Trial name or title

\begin{tabular}{l|l}
\hline Methods & $\begin{array}{l}\text { Allocation: randomised } \\
\text { End point classification: safety/efficacy study }\end{array}$ \\
& $\begin{array}{l}\text { Intervention model: parallel assignment } \\
\text { Masking: double-blind (subject, caregiver, investigator, outcomes assessor) } \\
\text { Primary purpose: treatment }\end{array}$ \\
\hline Participants & $\begin{array}{l}\text { Inclusion criteria of the trial } \\
\text { - } 12 \text { to } 60 \text { years } \\
\text { - Confirmation of clinical diagnosis of atrophic and erosive lichen planus by histological examination } \\
\text { - Atrophic and erosive lesion greater than } 1 \mathrm{~cm} \text { pain } \\
\text { - Burning greater than } 3.5 \text { in VAS Score }\end{array}$ \\
\hline
\end{tabular}

Interventions Quercetin (flavonoid with therapeutical anti-inflammatory and antioxidant action) vs placebo, both capsules BD 1 month

\section{Outcomes Primary outcomes of the trial}

- The effects of this Drug on OLP measured with VAS scale for pain and evaluation of intensity of lesions (time frame: 2 months)

(VAS used to evaluate pain, intensity of lesions recorded weekly, and any side-effects)

Starting date April 2010 (expected completion date July 2011)

Contact information Maryam Amirchaghmaghi, Assistant Professor (0098-0511889201, amirchakhmaghim@mums.ac.ir)

Notes $\quad$ Iran


DATA ANDANALYSES

Comparison 1. Pimecrolimus versus placebo/vehicle cream

\begin{tabular}{|c|c|c|c|c|}
\hline Outcome or subgroup title & $\begin{array}{l}\text { No. of } \\
\text { studies }\end{array}$ & $\begin{array}{c}\text { No. of } \\
\text { participants }\end{array}$ & Statistical method & Effect size \\
\hline $\begin{array}{l}1 \text { Pain reduction using visual } \\
\text { analogue scale (VAS) }\end{array}$ & 2 & & Mean Difference (IV, Fixed, 95\% CI) & Totals not selected \\
\hline $\begin{array}{c}1.11 \% \text { pimecrolimus cream } \\
\text { versus placebo ( } 0 \text { to } 100 \text { score) }\end{array}$ & 1 & & Mean Difference (IV, Fixed, 95\% CI) & $0.0[0.0,0.0]$ \\
\hline $\begin{array}{l}1.21 \% \text { pimecrolimus versus } \\
\text { placebo (0 to } 4 \text { score for basal } \\
\text { pain) }\end{array}$ & 1 & & Mean Difference (IV, Fixed, 95\% CI) & $0.0[0.0,0.0]$ \\
\hline $\begin{array}{l}1.31 \% \text { pimecrolimus versus } \\
\text { placebo ( } 0 \text { to } 4 \text { score for feeding } \\
\text { pain) }\end{array}$ & 1 & & Mean Difference (IV, Fixed, 95\% CI) & $0.0[0.0,0.0]$ \\
\hline $\begin{array}{l}2 \text { Physician Global Assessment: } \\
\text { Weighted sums of ulceration, } \\
\text { erythema and reticulation } \\
\left(\mathrm{mm}^{2}\right)\end{array}$ & 1 & & Mean Difference (IV, Fixed, 95\% CI) & Totals not selected \\
\hline $\begin{array}{l}2.11 \% \text { pimecrolimus versus } \\
\text { placebo }\end{array}$ & 1 & & Mean Difference (IV, Fixed, 95\% CI) & $0.0[0.0,0.0]$ \\
\hline $\begin{array}{l}3 \text { Physician Global Assessment: } \\
\text { Surface of erosive lesions }\end{array}$ & 1 & & Mean Difference (IV, Fixed, 95\% CI) & Totals not selected \\
\hline $\begin{array}{l}3.11 \% \text { pimecrolimus versus } \\
\text { placebo ( } 0 \text { to } 4 \text { score) }\end{array}$ & 1 & & Mean Difference (IV, Fixed, 95\% CI) & $0.0[0.0,0.0]$ \\
\hline 4 Physician Global Assessment & 1 & & Risk Ratio (IV, Fixed, 95\% CI) & Totals not selected \\
\hline $\begin{array}{l}5 \text { Clinical response: Complete } \\
\text { clearance }\end{array}$ & 1 & & Risk Ratio (M-H, Fixed, 95\% CI) & Totals not selected \\
\hline
\end{tabular}

\section{Comparison 2. Clobetasol propionate versus active treatment}

\begin{tabular}{|c|c|c|c|c|}
\hline Outcome or subgroup title & $\begin{array}{l}\text { No. of } \\
\text { studies }\end{array}$ & $\begin{array}{c}\text { No. of } \\
\text { participants }\end{array}$ & Statistical method & Effect size \\
\hline $\begin{array}{l}1 \text { Pain reduction using visual } \\
\text { analogue scale (VAS) }\end{array}$ & 3 & & Mean Difference (IV, Fixed, 95\% CI) & Totals not selected \\
\hline $\begin{array}{l}1.10 .025 \% \\
\text { clobetasol- } 17 \text {-propionate vs } \\
0.025 \% \text { lipophilic ointment in } \\
\text { hydrophilic phase ( } 0 \text { to } 100 \\
\text { score) }\end{array}$ & 1 & & Mean Difference (IV, Fixed, 95\% CI) & $0.0[0.0,0.0]$ \\
\hline $\begin{array}{l}1.20 .05 \% \text { clobetasol } \\
\text { propionate versus } 5 \% \\
\text { mesalazine gel ( } 0 \text { to } 10 \text { score })\end{array}$ & 1 & & Mean Difference (IV, Fixed, 95\% CI) & $0.0[0.0,0.0]$ \\
\hline
\end{tabular}


$1.30 .025 \%$ clobetasol propionate versus $0.05 \%$ clobetasol propionate (0 to 10 score)

2 Improvement in pain symptoms by VAS ( $>=50 \%)$

$2.10 .025 \%$ vs $0.05 \%$ clobetasol propionate (no symptoms versus partial or no response)

3 Physician Global Assessment (Thongprasom score)

$$
3.10 .025 \%
$$

clobetasol-17-propionate versus $0.025 \%$ conventional formulation

$3.20 .025 \%$ clobetasol propionate versus $0.05 \%$ clobetasol propionate

4 Physician Global Assessment

(Thongprasom score) $4.10 .025 \%$ clobetasol propionate versus $0.05 \%$ clobetasol propionate

1

1

1
Mean Difference (IV, Fixed, 95\% CI)

$0.0[0.0,0.0]$

Risk Ratio (M-H, Fixed, 95\% CI)

Risk Ratio (M-H, Fixed, 95\% CI)

Totals not selected

$0.0[0.0,0.0]$

Mean Difference (IV, Fixed, 95\% CI)

Totals not selected

Mean Difference (IV, Fixed, 95\% CI)

$0.0[0.0,0.0]$

Mean Difference (IV, Fixed, 95\% CI)

$0.0[0.0,0.0]$

Risk Ratio (M-H, Fixed, 95\% CI)

Totals not selected

Risk Ratio (M-H, Fixed, 95\% CI)

$0.0[0.0,0.0]$

\section{Comparison 3. $\quad 0.1 \%$ Triamcinolone acetonide versus ciclosporin}

\begin{tabular}{|c|c|c|c|c|}
\hline Outcome or subgroup title & $\begin{array}{l}\text { No. of } \\
\text { studies }\end{array}$ & $\begin{array}{c}\text { No. of } \\
\text { participants }\end{array}$ & Statistical method & Effect size \\
\hline $\begin{array}{l}1 \text { Pain reduction using visual } \\
\text { analogue scale (VAS) (0 to } 100 \\
\text { scale) }\end{array}$ & 1 & & Mean Difference (IV, Fixed, 95\% CI) & Totals not selected \\
\hline $\begin{array}{l}2 \text { Physician Global Assessment } \\
\text { (Thongprasom score) }\end{array}$ & 1 & & Mean Difference (IV, Fixed, 95\% CI) & Totals not selected \\
\hline
\end{tabular}

\section{Comparison 4. $\quad 0.1 \%$ Tacrolimus versus $0.05 \%$ clobetasol}

\begin{tabular}{|c|c|c|c|c|}
\hline Outcome or subgroup title & $\begin{array}{l}\text { No. of } \\
\text { studies }\end{array}$ & $\begin{array}{c}\text { No. of } \\
\text { participants }\end{array}$ & Statistical method & Effect size \\
\hline $\begin{array}{l}1 \text { Pain reduction using the VAS ( } 0 \\
\text { to } 10 \text { score) }\end{array}$ & 1 & & Mean Difference (Fixed, 95\% CI) & Totals not selected \\
\hline
\end{tabular}




\begin{tabular}{|c|c|c|c|c|}
\hline Outcome or subgroup title & $\begin{array}{l}\text { No. of } \\
\text { studies }\end{array}$ & $\begin{array}{c}\text { No. of } \\
\text { participants }\end{array}$ & Statistical method & Effect size \\
\hline $\begin{array}{l}1 \text { Improvement in pain symptoms } \\
\text { by VAS }(>=50 \%) \text { (Complete } \\
\text { or good response versus poor or } \\
\text { no response) }\end{array}$ & 1 & & Risk Ratio (M-H, Fixed, 95\% CI) & Totals not selected \\
\hline $\begin{array}{l}2 \text { Physician Global Assessment } \\
\text { (Thongprasom score) }\end{array}$ & 1 & & Risk Ratio (M-H, Fixed, 95\% CI) & Totals not selected \\
\hline
\end{tabular}

Comparison 6. Ciclosporin versus active treatment

\begin{tabular}{|c|c|c|c|c|}
\hline Outcome or subgroup title & $\begin{array}{l}\text { No. of } \\
\text { studies }\end{array}$ & $\begin{array}{c}\text { No. of } \\
\text { participants }\end{array}$ & Statistical method & Effect size \\
\hline $\begin{array}{l}1 \text { Improvement in pain symptoms } \\
\text { by VAS (> = 50\%) (no } \\
\text { symptoms versus partial or no } \\
\text { response) }\end{array}$ & 1 & & Risk Ratio (M-H, Fixed, 95\% CI) & Totals not selected \\
\hline $\begin{array}{l}1.11 .5 \% \text { Ciclosporin versus } \\
0.025 \% \text { clobetasol }\end{array}$ & 1 & & Risk Ratio (M-H, Fixed, 95\% CI) & $0.0[0.0,0.0]$ \\
\hline $\begin{array}{l}2 \text { Physician Global Assessment } \\
\text { (Thongprasom score) }\end{array}$ & 1 & & Risk Ratio (M-H, Fixed, 95\% CI) & Totals not selected \\
\hline $\begin{array}{l}2.11 .5 \% \text { ciclosporin versus } \\
0.025 \% \text { clobetasol propionate }\end{array}$ & 1 & & Risk Ratio (M-H, Fixed, 95\% CI) & $0.0[0.0,0.0]$ \\
\hline $\begin{array}{l}3 \text { Physician Global Assessment: } \\
\text { Severity of disease }\end{array}$ & 1 & & Mean Difference (IV, Fixed, 95\% CI) & Totals not selected \\
\hline $\begin{array}{l}3.1 \text { Ciclosporin versus vehicle } \\
\text { (0 to } 3 \text { score) }\end{array}$ & 1 & & Mean Difference (IV, Fixed, 95\% CI) & $0.0[0.0,0.0]$ \\
\hline
\end{tabular}

\section{Comparison 7. Radix tripterygium hypoglaucum (THT) vs tripterygium glucosides (TGT)}

\begin{tabular}{|c|c|c|c|c|}
\hline Outcome or subgroup title & $\begin{array}{l}\text { No. of } \\
\text { studies }\end{array}$ & $\begin{array}{c}\text { No. of } \\
\text { participants }\end{array}$ & Statistical method & Effect size \\
\hline $\begin{array}{l}1 \text { Physician Global Assessment: } \\
\text { Cure of erosive lesions }\end{array}$ & 1 & & Risk Ratio (M-H, Fixed, 95\% CI) & Totals not selected \\
\hline 1.1 Grade I lesions & 1 & & Risk Ratio (M-H, Fixed, 95\% CI) & $0.0[0.0,0.0]$ \\
\hline 1.2 Grade II lesions & 1 & & Risk Ratio (M-H, Fixed, 95\% CI) & $0.0[0.0,0.0]$ \\
\hline
\end{tabular}


Comparison 8. Flucinonide vs placebo

\begin{tabular}{|c|c|c|c|c|}
\hline Outcome or subgroup title & $\begin{array}{l}\text { No. of } \\
\text { studies }\end{array}$ & $\begin{array}{c}\text { No. of } \\
\text { participants }\end{array}$ & Statistical method & Effect size \\
\hline $\begin{array}{c}1 \text { Physician Global Assessment: } \\
\text { Clinical signs (Complete vs } \\
\text { good, partial, or no response) }\end{array}$ & 1 & & Risk Ratio (M-H, Fixed, 95\% CI) & Totals not selected \\
\hline
\end{tabular}

\section{Comparison 9. Betamethasone versus $0.1 \%$ triamcinolone acetonide}

\begin{tabular}{|c|c|c|c|c|}
\hline Outcome or subgroup title & $\begin{array}{l}\text { No. of } \\
\text { studies }\end{array}$ & $\begin{array}{c}\text { No. of } \\
\text { participants }\end{array}$ & Statistical method & Effect size \\
\hline $\begin{array}{l}1 \text { Physician Global Assessment: } \\
\text { Clinical severity (0 to } 12 \text { score) }\end{array}$ & 1 & & Mean Difference (Fixed, 95\% CI) & Totals not selected \\
\hline
\end{tabular}

Analysis I.I. Comparison I Pimecrolimus versus placebo/vehicle cream, Outcome I Pain reduction using visual analogue scale (VAS).

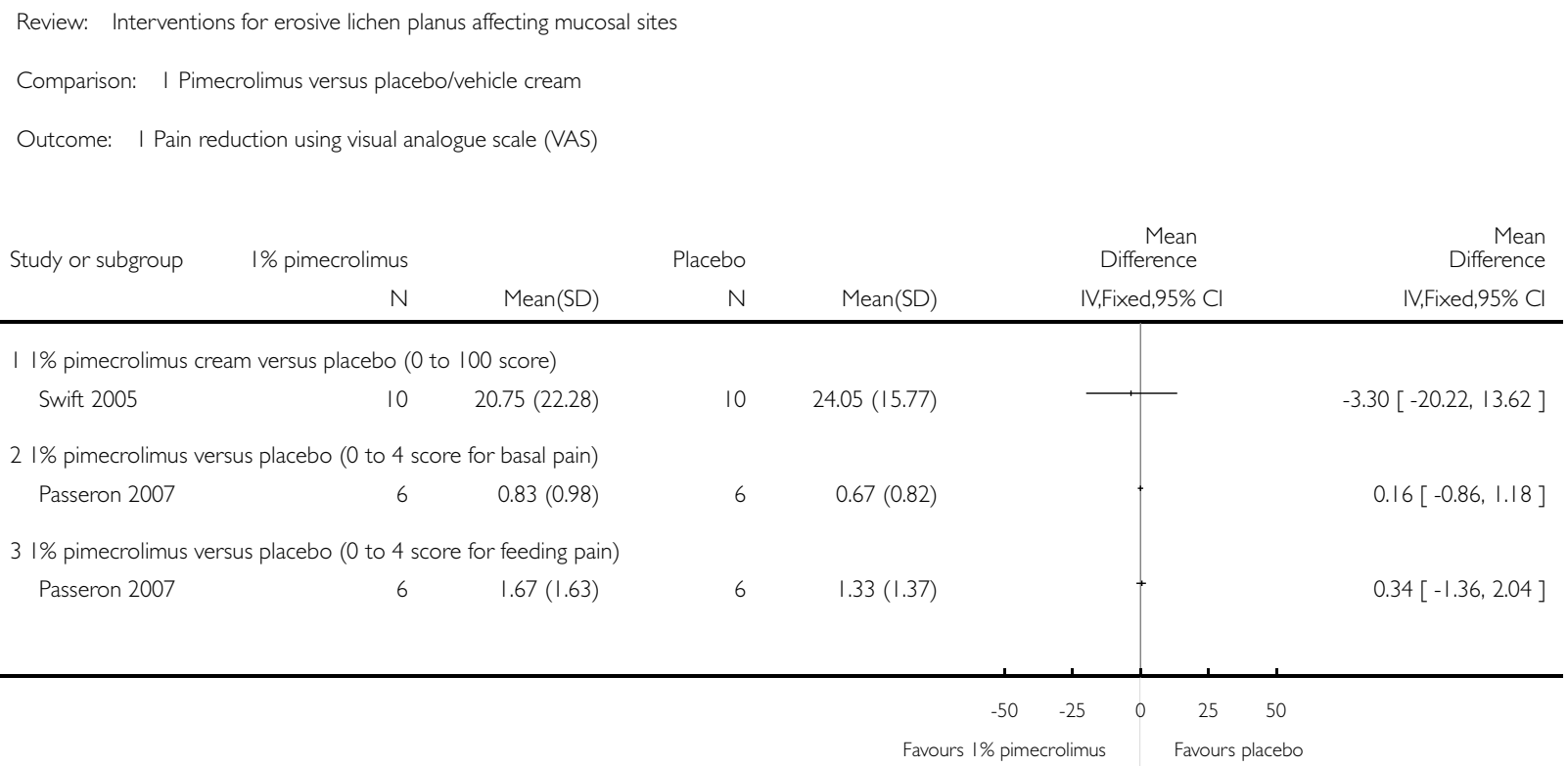


Analysis I.2. Comparison I Pimecrolimus versus placebo/vehicle cream, Outcome 2 Physician Global Assessment: Weighted sums of ulceration, erythema and reticulation $\left(\mathrm{mm}^{2}\right)$.

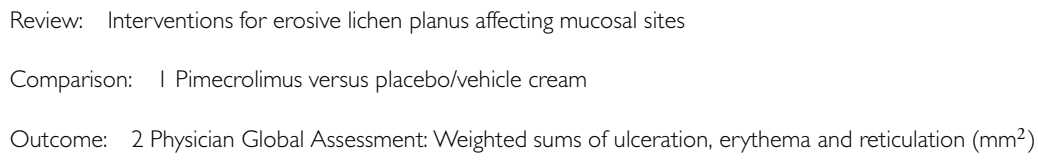

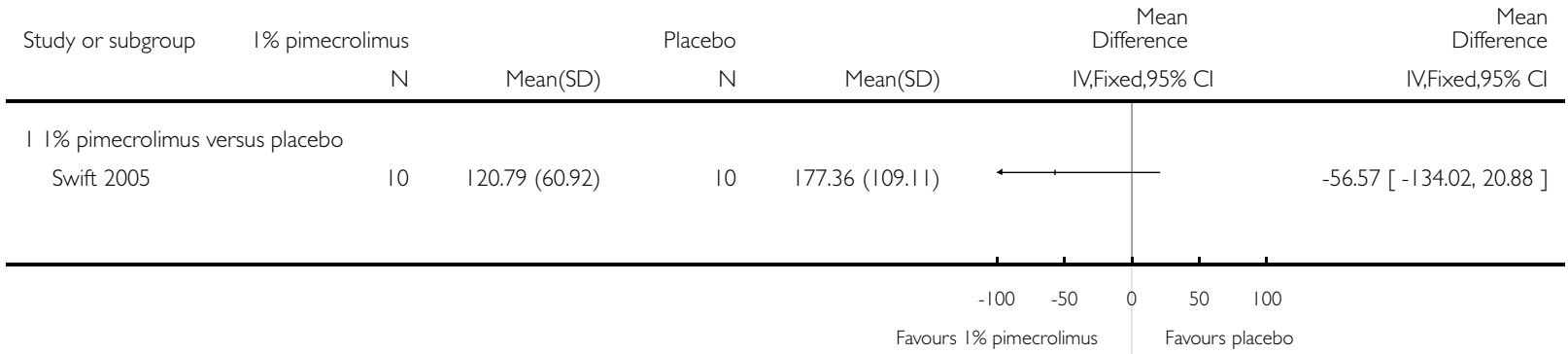

\section{Analysis I.3. Comparison I Pimecrolimus versus placebo/vehicle cream, Outcome 3 Physician Global} Assessment: Surface of erosive lesions.

Review: Interventions for erosive lichen planus affecting mucosal sites

Comparison: I Pimecrolimus versus placebo/vehicle cream

Outcome: 3 Physician Global Assessment: Surface of erosive lesions

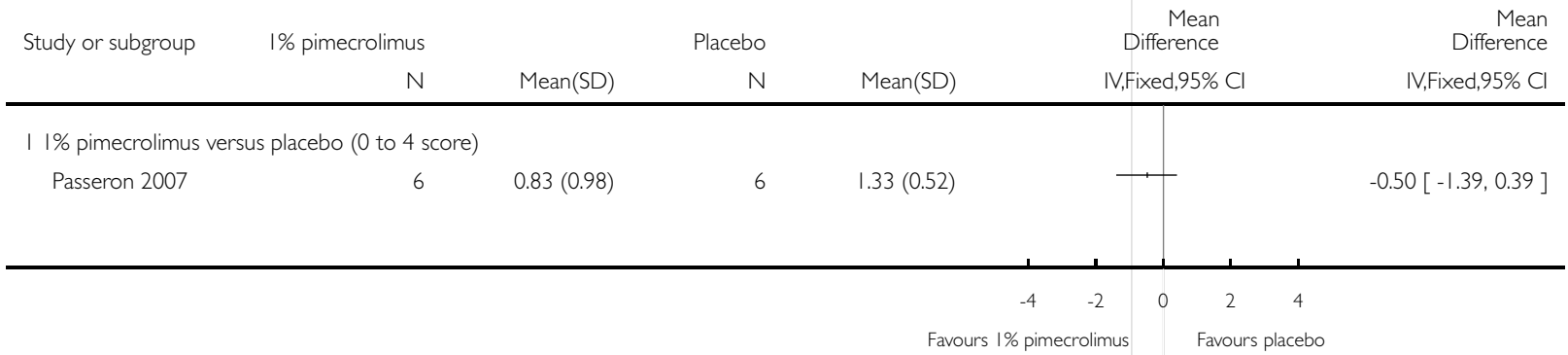


Analysis I.4. Comparison I Pimecrolimus versus placebo/vehicle cream, Outcome 4 Physician Global Assessment.

Review: Interventions for erosive lichen planus affecting mucosal sites

Comparison: I Pimecrolimus versus placebo/vehicle cream

Outcome: 4 Physician Global Assessment

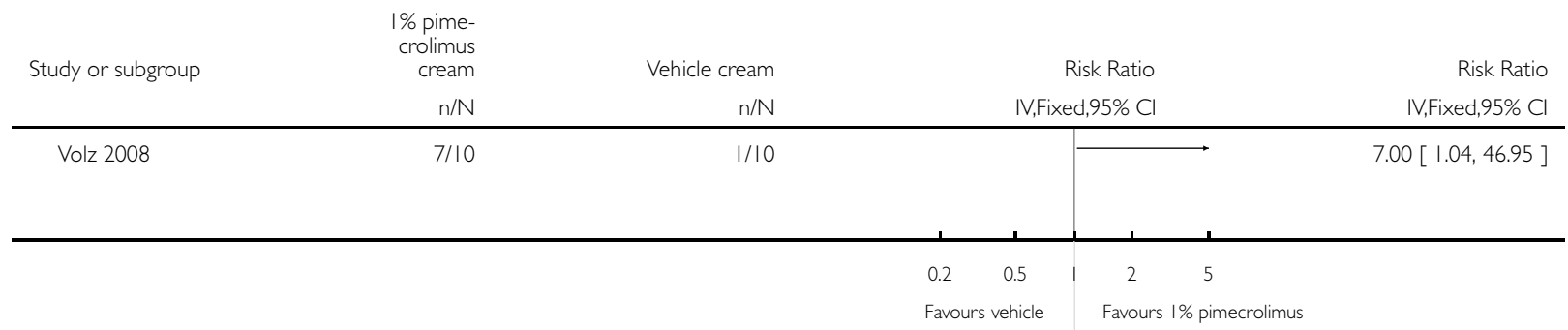

Analysis I.5. Comparison I Pimecrolimus versus placebo/vehicle cream, Outcome 5 Clinical response: Complete clearance.

Review: Interventions for erosive lichen planus affecting mucosal sites

Comparison: | Pimecrolimus versus placebo/vehicle cream

Outcome: 5 Clinical response: Complete clearance

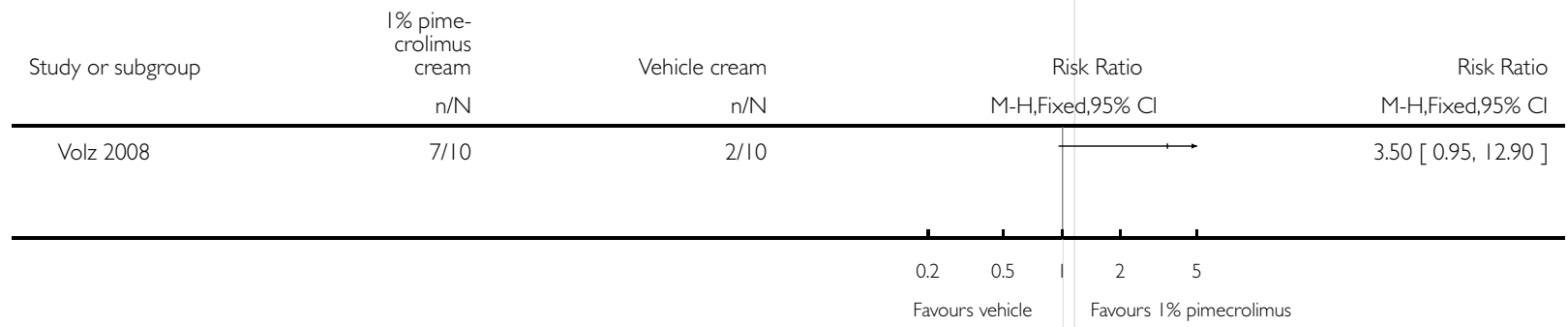


Analysis 2.I. Comparison 2 Clobetasol propionate versus active treatment, Outcome I Pain reduction using visual analogue scale (VAS).

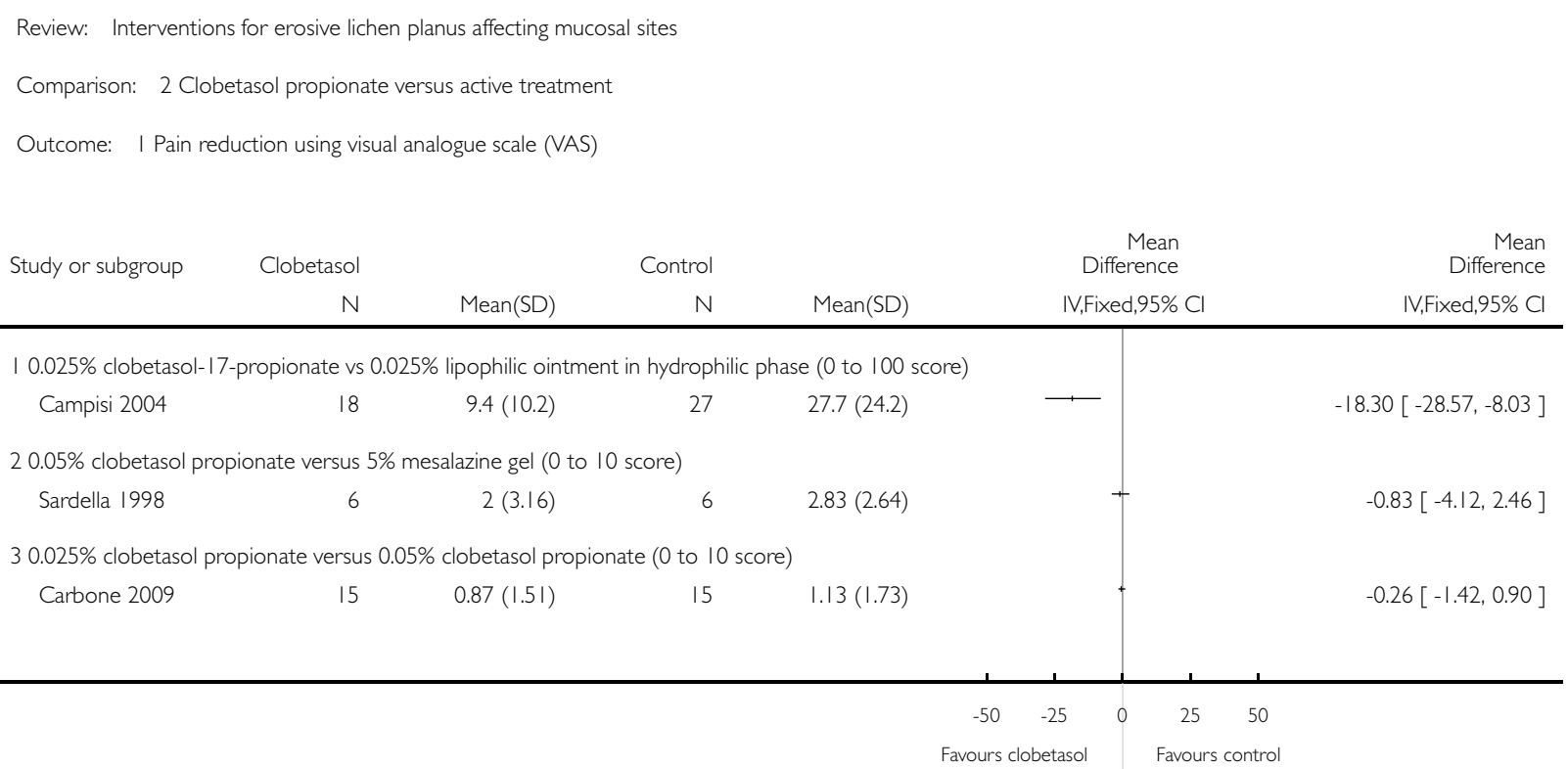

\section{Analysis 2.2. Comparison 2 Clobetasol propionate versus active treatment, Outcome 2 Improvement in} pain symptoms by VAS (> = 50\%).

Review: Interventions for erosive lichen planus affecting mucosal sites

Comparison: 2 Clobetasol propionate versus active treatment

Outcome: 2 Improvement in pain symptoms by VAS ( $>=50 \%)$

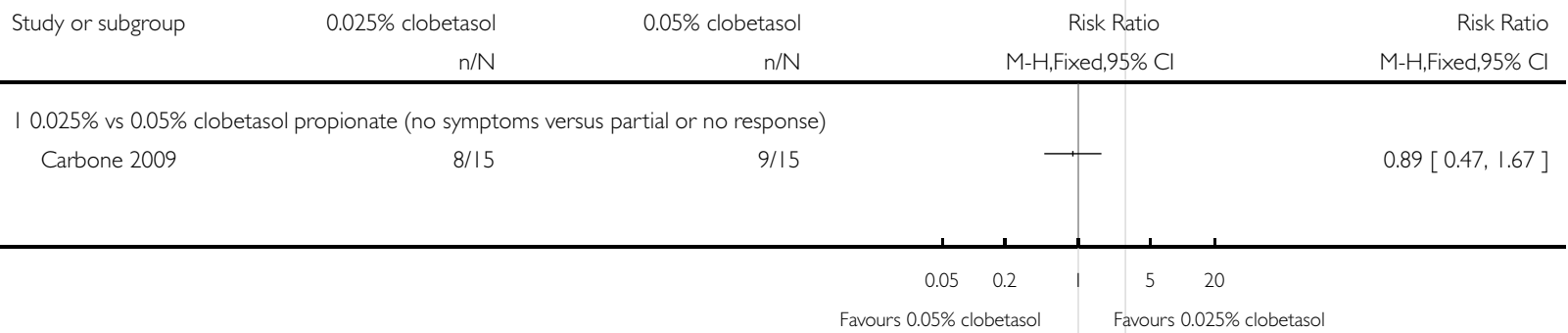


Analysis 2.3. Comparison 2 Clobetasol propionate versus active treatment, Outcome 3 Physician Global Assessment (Thongprasom score).

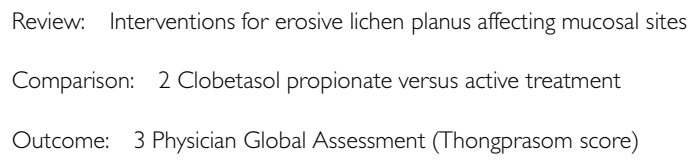

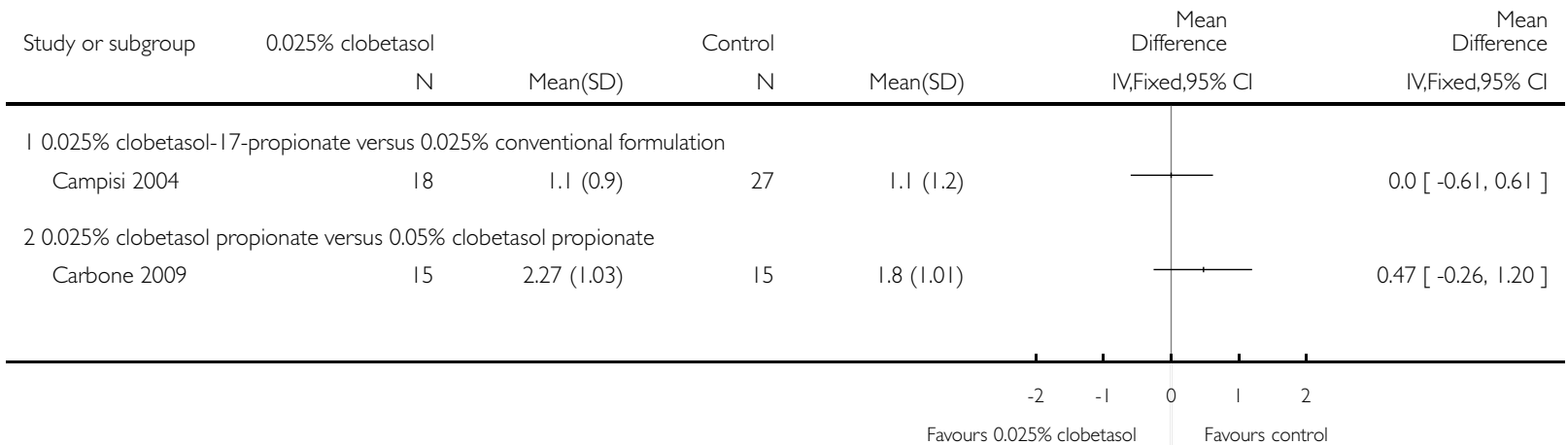

Analysis 2.4. Comparison 2 Clobetasol propionate versus active treatment, Outcome 4 Physician Global Assessment (Thongprasom score).

Review: Interventions for erosive lichen planus affecting mucosal sites

Comparison: 2 Clobetasol propionate versus active treatment

Outcome: 4 Physician Global Assessment (Thongprasom score)

\begin{tabular}{|c|c|c|c|c|}
\hline Study or subgroup & $0.025 \%$ clobetasol & $0.05 \%$ clobetasol & Risk Ratio & Risk Ratio \\
\hline & $\mathrm{n} / \mathrm{N}$ & $\mathrm{n} / \mathrm{N}$ & M-H,Fixed,95\% Cl & M-H,Fixed,95\% Cl \\
\hline
\end{tabular}

| $0.025 \%$ clobetasol propionate versus $0.05 \%$ clobetasol propionate

Carbone 2009

$7 / 15$

$1.14[0.56,2.35]$ 
Analysis 3.I. Comparison 3 0.1\% Triamcinolone acetonide versus ciclosporin, Outcome I Pain reduction using visual analogue scale (VAS) (0 to 100 scale).

Review: Interventions for erosive lichen planus affecting mucosal sites

Comparison: 3 0.1\% Triamcinolone acetonide versus ciclosporin

Outcome: I Pain reduction using visual analogue scale (VAS) (0 to 100 scale)

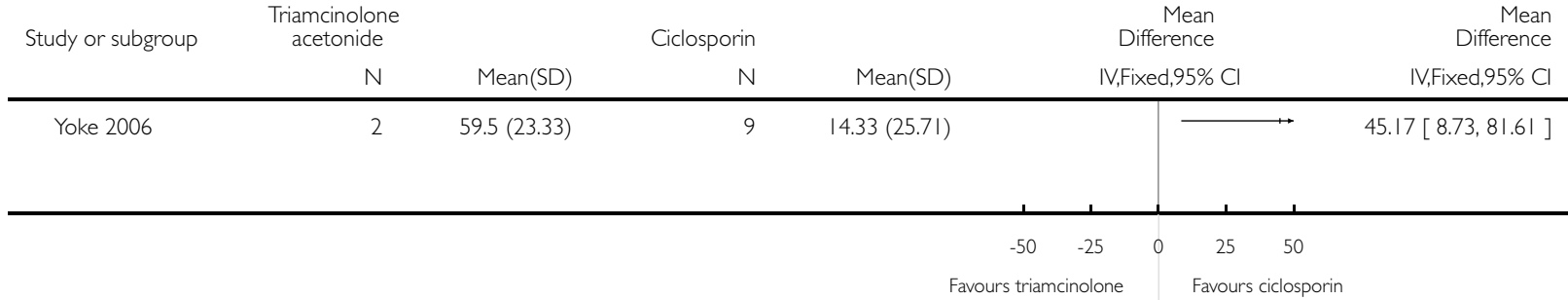

Analysis 3.2. Comparison $\mathbf{3} \mathbf{0 . 1} \%$ Triamcinolone acetonide versus ciclosporin, Outcome 2 Physician Global Assessment (Thongprasom score).

Review: Interventions for erosive lichen planus affecting mucosal sites

Comparison: $30.1 \%$ Triamcinolone acetonide versus ciclosporin

Outcome: 2 Physician Global Assessment (Thongprasom score)

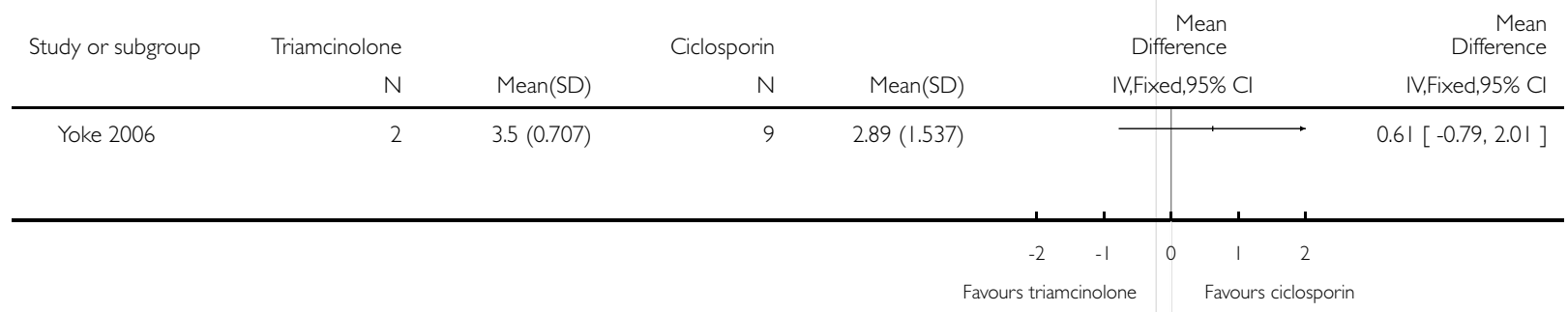


Analysis 4. I. Comparison 4 0.1\% Tacrolimus versus $0.05 \%$ clobetasol, Outcome I Pain reduction using the VAS (0 to 10 score).

Review: Interventions for erosive lichen planus affecting mucosal sites

Comparison: $40.1 \%$ Tacrolimus versus $0.05 \%$ clobetasol

Outcome: I Pain reduction using the VAS (0 to 10 score)

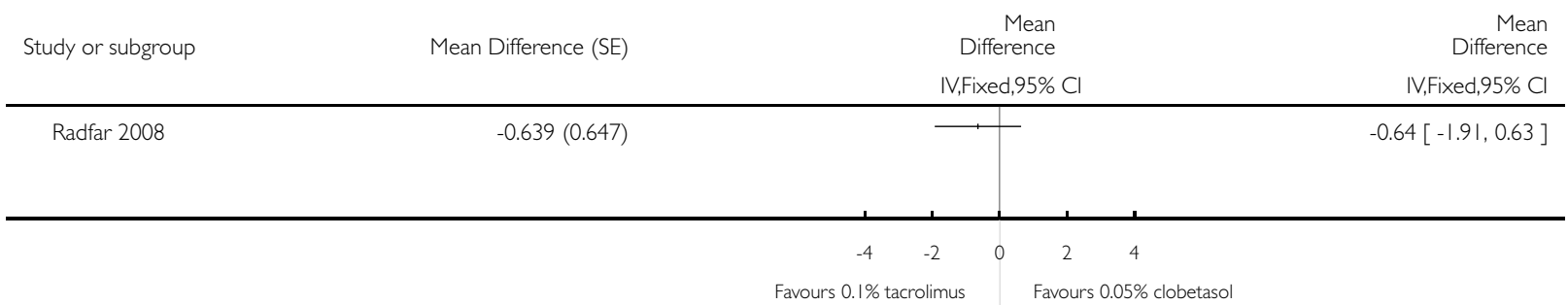

Analysis 5.I. Comparison 5 Aloe vera gel versus placebo, Outcome I Improvement in pain symptoms by VAS $(>=50 \%$ ) (Complete or good response versus poor or no response).

Review: Interventions for erosive lichen planus affecting mucosal sites

Comparison: 5 Aloe vera gel versus placebo

Outcome: I Improvement in pain symptoms by VAS ( $>=50 \%$ ) (Complete or good response versus poor or no response)

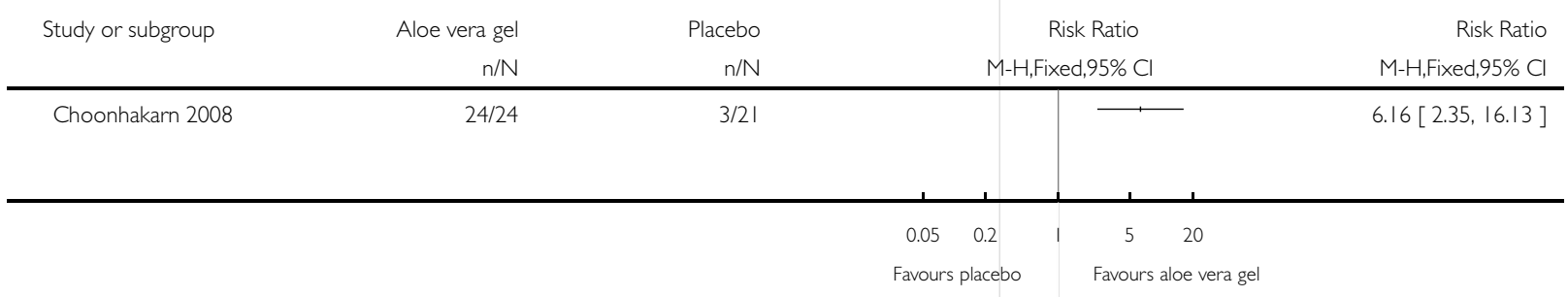


Analysis 5.2. Comparison 5 Aloe vera gel versus placebo, Outcome 2 Physician Global Assessment (Thongprasom score).

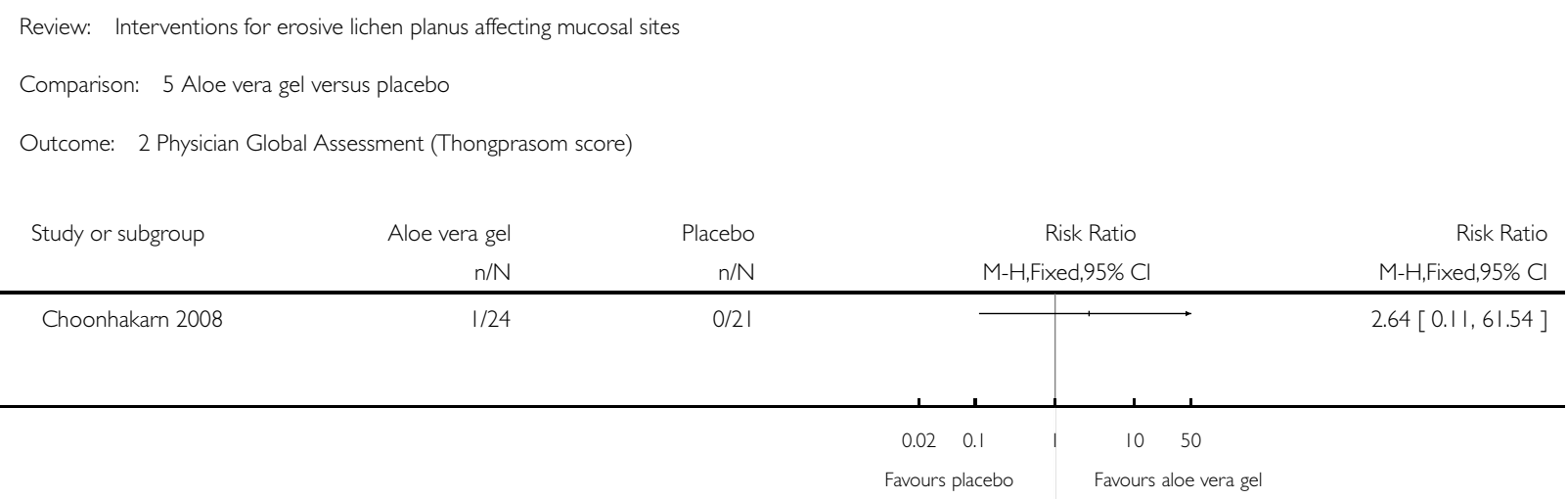

Analysis 6.I. Comparison 6 Ciclosporin versus active treatment, Outcome I Improvement in pain symptoms by VAS (> = 50\%) (no symptoms versus partial or no response).

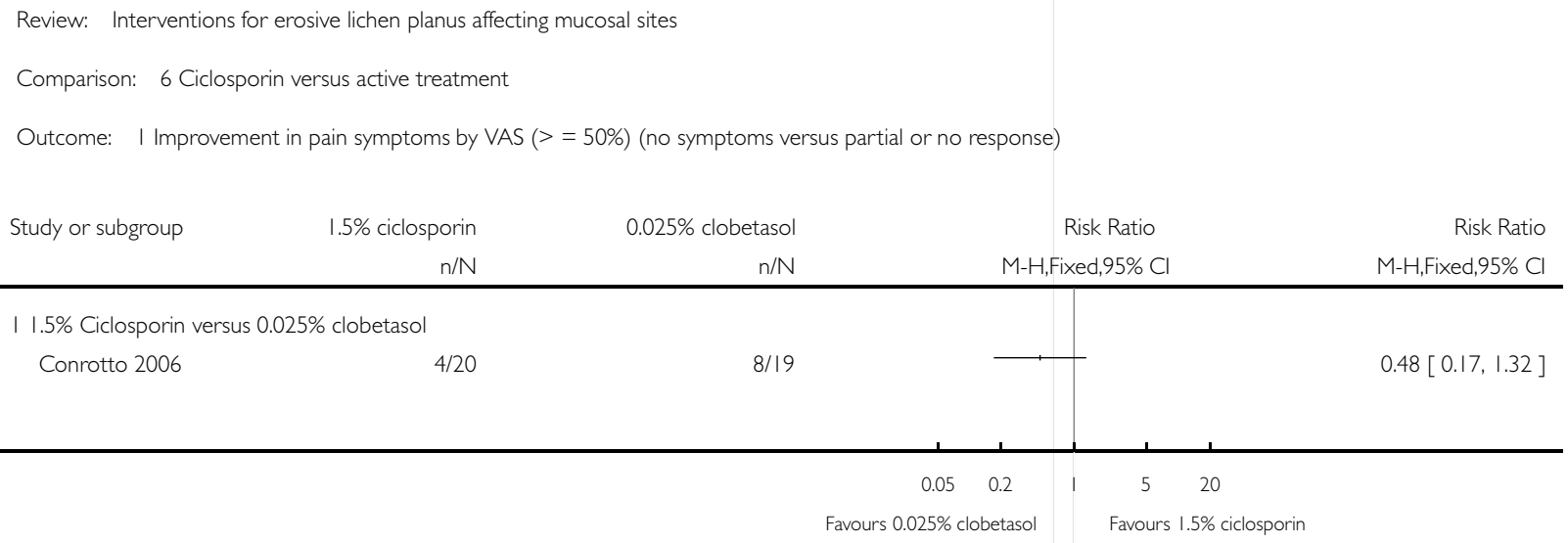




\section{Analysis 6.2. Comparison 6 Ciclosporin versus active treatment, Outcome 2 Physician Global Assessment} (Thongprasom score).

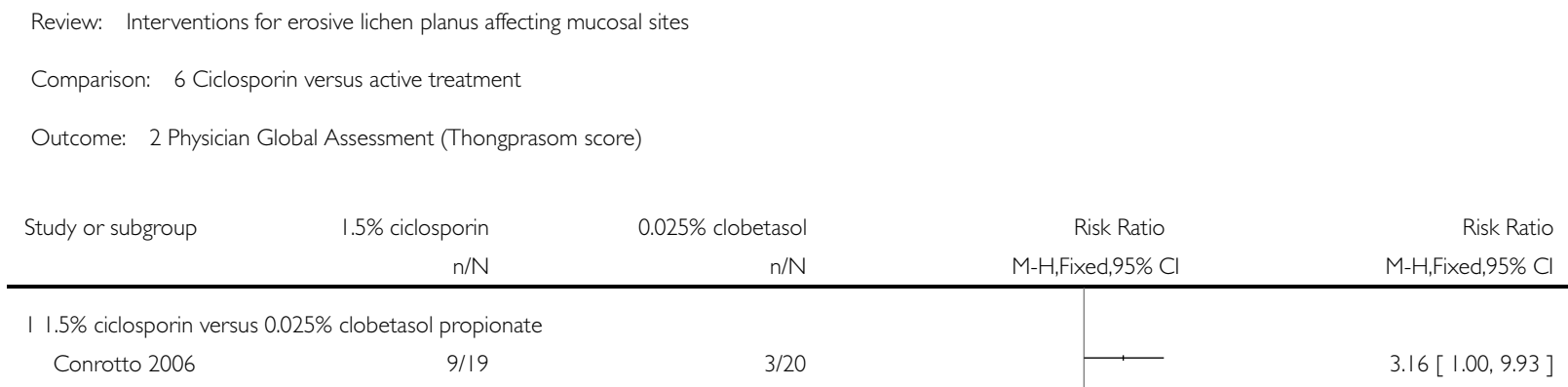

Analysis 6.3. Comparison 6 Ciclosporin versus active treatment, Outcome 3 Physician Global Assessment: Severity of disease.

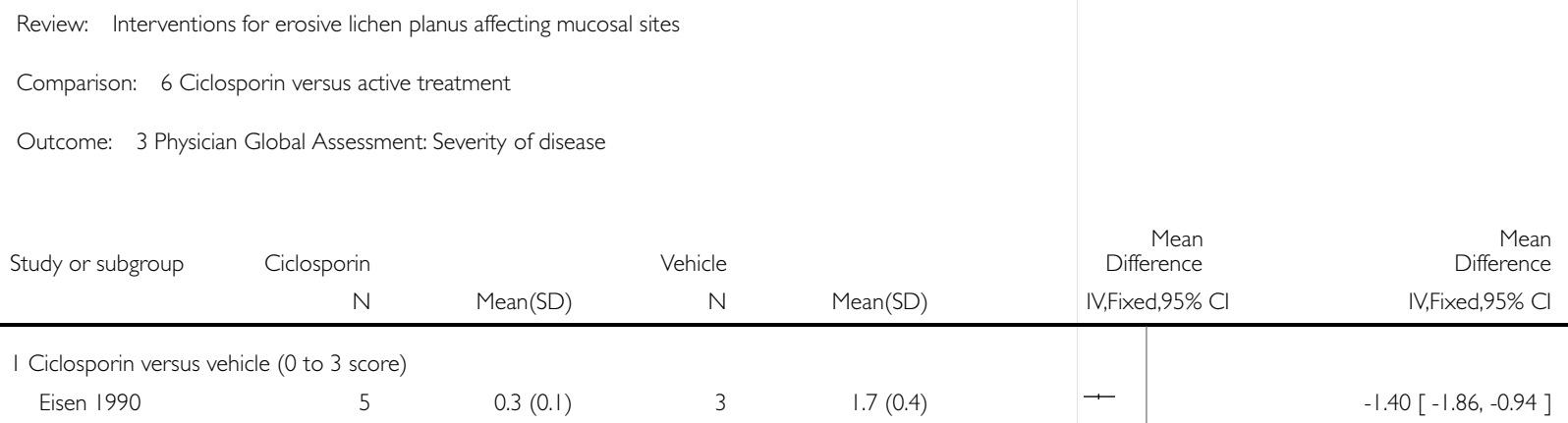

-


Analysis 7.I. Comparison 7 Radix tripterygium hypoglaucum (THT) vs tripterygium glucosides (TGT), Outcome I Physician Global Assessment: Cure of erosive lesions.

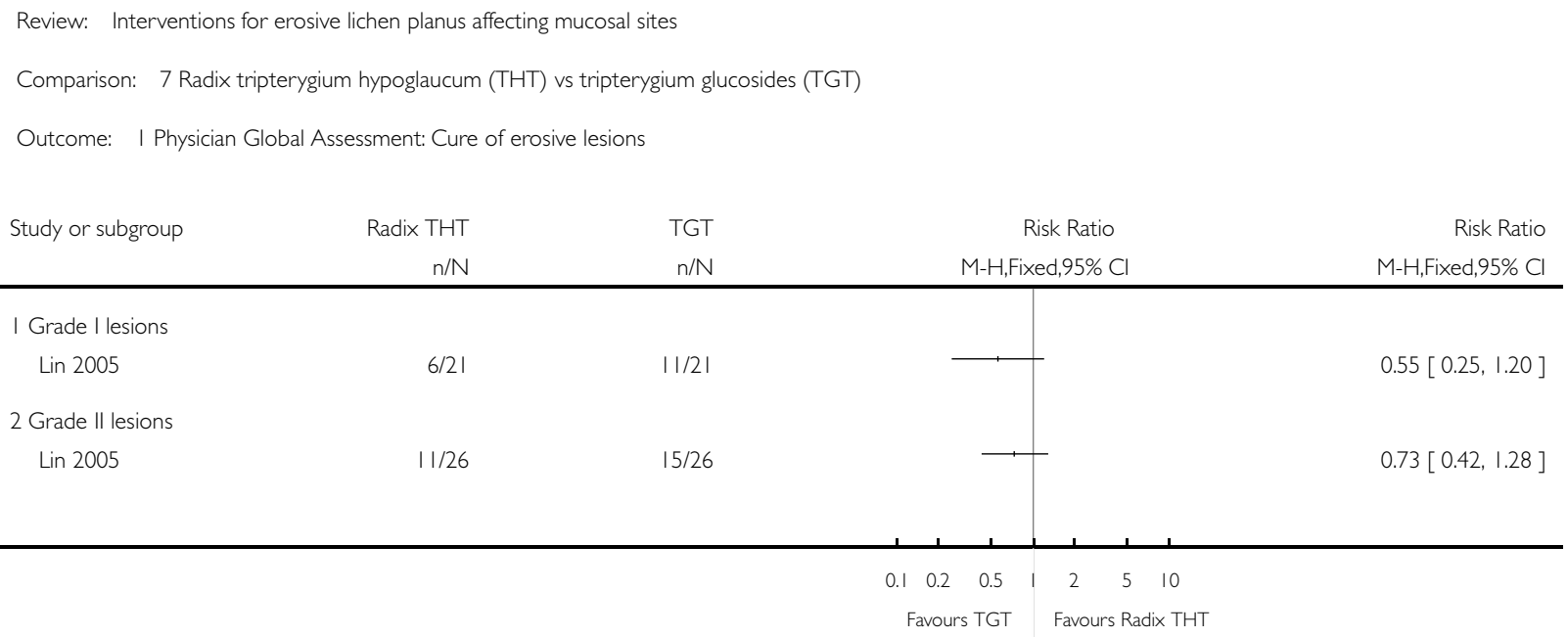

Analysis 8.I. Comparison 8 Flucinonide vs placebo, Outcome I Physician Global Assessment: Clinical signs (Complete vs good, partial, or no response).

Review: Interventions for erosive lichen planus affecting mucosal sites

Comparison: 8 Flucinonide vs placebo

Outcome: I Physician Global Assessment: Clinical signs (Complete vs good, partial, or no response)

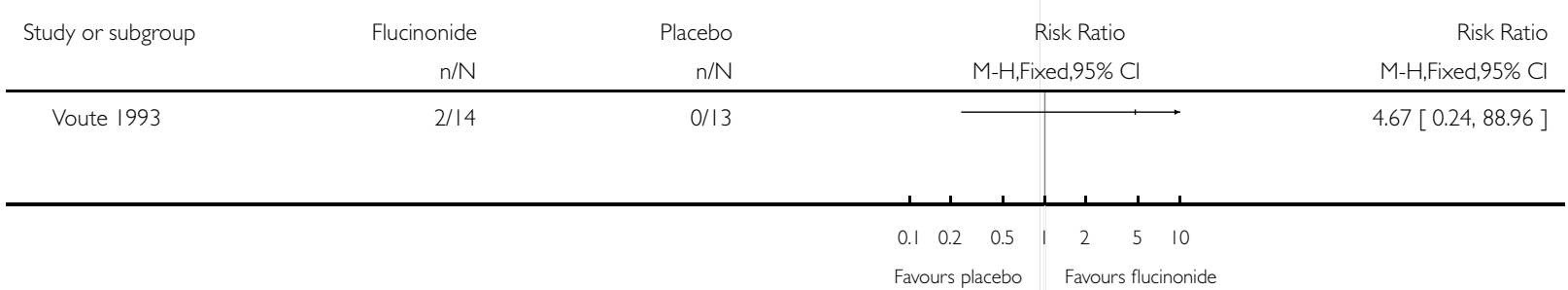


Analysis 9.1. Comparison 9 Betamethasone versus $0.1 \%$ triamcinolone acetonide, Outcome I Physician Global Assessment: Clinical severity (0 to 12 score).

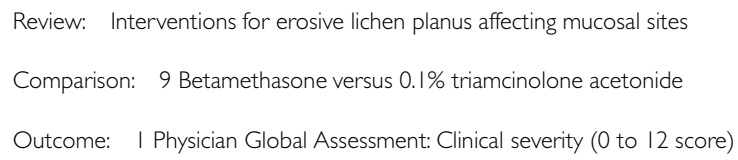

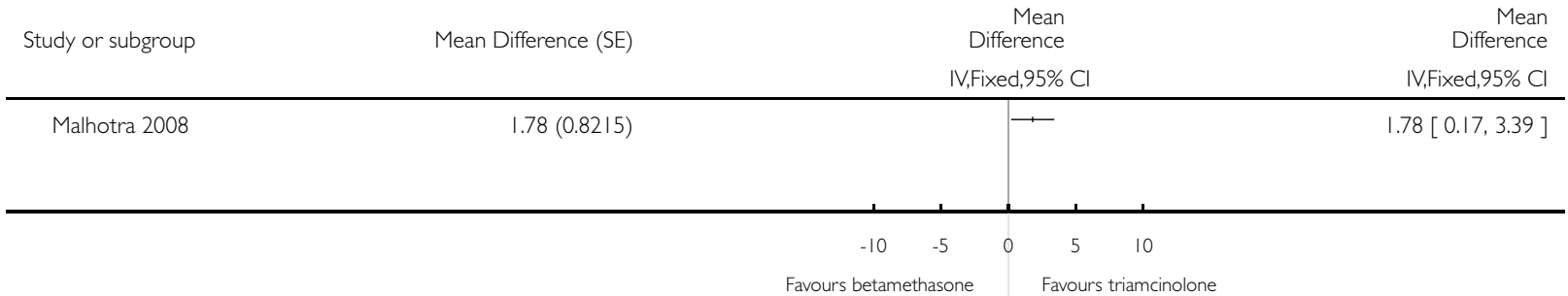

\section{ADDITIONAL TABLES}

Table 1. Summary of included studies

\begin{tabular}{|c|c|c|c|c|c|c|c|c|c|c|c|c|}
\hline & & $\begin{array}{l}\text { Inter- } \\
\text { vention } \\
1\end{array}$ & $\begin{array}{l}\text { Inter- } \\
\text { vention } \\
2\end{array}$ & $\begin{array}{l}\text { Fre- } \\
\text { quency }\end{array}$ & $\begin{array}{l}\text { Treat- } \\
\text { ment } \\
\text { Dura- } \\
\text { tion }\end{array}$ & $\begin{array}{l}\text { Assess- } \\
\text { ment } \\
\text { Points }\end{array}$ & $\begin{array}{l}{ }^{*} \text { Method } \\
\text { of Di- } \\
\text { agnosis }\end{array}$ & $\begin{array}{l}\text { Oral or } \\
\text { Genital }\end{array}$ & $\begin{array}{l}\text { Total } \\
\text { Ran- } \\
\text { domised }\end{array}$ & $\begin{array}{l}\text { All Ero- } \\
\text { sive? }\end{array}$ & $\begin{array}{l}\text { ELP } \\
\text { Ran- } \\
\text { domised }\end{array}$ & $\begin{array}{l}\text { Re- } \\
\text { ported } \\
\text { Results }\end{array}$ \\
\hline 1 & $\begin{array}{l}\text { Passeron } \\
2007\end{array}$ & $\begin{array}{l}1 \% \\
\text { Pime- } \\
\text { crolimus } \\
\text { cream }\end{array}$ & Placebo & $\mathrm{BD}$ & 4 weeks & $\begin{array}{l}\text { Week } 0 \text {, } \\
4 \text {, and } 8\end{array}$ & $\begin{array}{l}\text { Histol- } \\
\text { ogy and } \\
\text { clinical }\end{array}$ & Oral & 12 & Yes & 12 & $\begin{array}{l}1 \% \\
\text { Pime- } \\
\text { crolimus } \\
\text { cream } \\
\text { effective } \\
\text { com- } \\
\text { pared } \\
\text { with } \\
\text { placebo }\end{array}$ \\
\hline 2 & $\begin{array}{l}\text { Swift } \\
2005\end{array}$ & $\begin{array}{l}1 \% \\
\text { Pime- } \\
\text { crolimus } \\
\text { cream }\end{array}$ & Placebo & $\mathrm{BD}$ & 4 weeks & $\begin{array}{l}\text { Week } 0 \text {, } \\
2 \text {, and } 4\end{array}$ & $\begin{array}{l}\text { Histol- } \\
\text { ogy and } \\
\text { clinical }\end{array}$ & Oral & 20 & Yes & 20 & $\begin{array}{l}\text { Signif- } \\
\text { icant re- } \\
\text { duc- } \\
\text { tion in } \\
\text { VAS (P } \\
=0.022 \text { ) } \\
\text { in treat- } \\
\text { ment } \\
\text { group, }\end{array}$ \\
\hline
\end{tabular}


Table 1. Summary of included studies (Continued)

\begin{tabular}{|c|c|c|c|c|c|c|c|c|c|c|c|c|}
\hline & & & & & & & & & & & & $\begin{array}{l}\text { but not } \\
\text { lesion } \\
\text { size }\end{array}$ \\
\hline 3 & $\begin{array}{l}\text { Volz } \\
2008\end{array}$ & $\begin{array}{l}1 \% \\
\text { Pime- } \\
\text { crolimus } \\
\text { cream }\end{array}$ & Placebo & $\mathrm{BD}$ & 30 days & $\begin{array}{l}\text { Day } 0 \text {, } \\
30 \text {, and } \\
60\end{array}$ & $\begin{array}{l}\text { Histol- } \\
\text { ogy and } \\
\text { clinical }\end{array}$ & Oral & 20 & Yes & 20 & $\begin{array}{l}\text { Signif- } \\
\text { icant re- } \\
\text { duc- } \\
\text { tion in } \\
\text { Investi- } \\
\text { gator } \\
\text { Global } \\
\text { Assess- } \\
\text { ment (P } \\
=0.032 \text { ) } \\
\text { in treat- } \\
\text { ment } \\
\text { group }\end{array}$ \\
\hline 4 & $\begin{array}{l}\text { Camp- } \\
\text { isi } \\
2004\end{array}$ & $\begin{array}{l}\text { Clobe- } \\
\text { tasol- } \\
17 \text {-pro- } \\
\text { pionate } \\
\text { lipid- } \\
\text { loaded } \\
\text { micro- } \\
\text { spheres } \\
0.025 \%\end{array}$ & $\begin{array}{l}\text { Con- } \\
\text { ven- } \\
\text { tional } \\
\text { lipophilic } \\
\text { oint- } \\
\text { ment } \\
\text { in hy- } \\
\text { drophilic } \\
\text { phase } 0 . \\
025 \%\end{array}$ & $\begin{array}{l}\text { BD for } \\
1 \\
\text { month } \\
\text { then } \\
\text { once } \\
\text { daily }\end{array}$ & $\begin{array}{l}2 \\
\text { months }\end{array}$ & $\begin{array}{l}\text { Month } \\
0, \quad 1 \text {, } \\
\text { and } 7\end{array}$ & $\begin{array}{l}\text { Histol- } \\
\text { ogy and } \\
\text { clinical }\end{array}$ & Oral & 50 & Yes & 50 & $\begin{array}{l}\text { No sig- } \\
\text { nifi- } \\
\text { cant dif- } \\
\text { ference }\end{array}$ \\
\hline 5 & $\begin{array}{l}\text { Car- } \\
\text { bone } \\
2009\end{array}$ & $\begin{array}{l}\text { Top- } \\
\text { ical clo- } \\
\text { betasol } \\
\text { propi- } \\
\text { onate } 0 . \\
025 \%\end{array}$ & $\begin{array}{l}\text { Top- } \\
\text { ical clo- } \\
\text { betasol } \\
\text { propi- } \\
\text { onate } 0 . \\
05 \%\end{array}$ & $\mathrm{BD}$ & $\begin{array}{l}2 \\
\text { months }\end{array}$ & $\begin{array}{l}\text { Week } 0 \text {, } \\
2,4,6 \text {, } \\
8, \text { and } \\
16\end{array}$ & $\begin{array}{l}\text { Histol- } \\
\text { ogy and } \\
\text { clinical } \\
\text { (WHO) }\end{array}$ & Oral & 35 & Yes & 35 & $\begin{array}{l}\text { No sig- } \\
\text { nifi- } \\
\text { cant dif- } \\
\text { ference }\end{array}$ \\
\hline 6 & $\begin{array}{l}\text { Radfar } \\
2008\end{array}$ & $\begin{array}{l}\text { Topical } \\
\text { tacrolimu: } \\
0.1 \% \\
\text { oint- } \\
\text { ment }\end{array}$ & $\begin{array}{l}\text { Top- } \\
\text { ical clo- } \\
\text { betasol } \\
0.05 \% \\
\text { oint- } \\
\text { ment }\end{array}$ & $\begin{array}{l}\text { QDS 2/ } \\
52 \\
\text { TDS 2/ } \\
52-\mathrm{BD} \\
1 / 52 \\
-\mathrm{OD} 1 / \\
52\end{array}$ & 6 weeks & $\begin{array}{l}\text { Week } 0 \text {, } \\
2 \text {, and } 6\end{array}$ & $\begin{array}{l}\text { Histol- } \\
\text { ogy and } \\
\text { clinical }\end{array}$ & Oral & 29 & Yes & 29 & $\begin{array}{l}\text { No sig- } \\
\text { nifi- } \\
\text { cant dif- } \\
\text { ference }\end{array}$ \\
\hline 7 & $\begin{array}{l}\text { Con- } \\
\text { rotto } \\
2006\end{array}$ & $\begin{array}{l}\text { Topical } \\
\text { ci- } \\
\text { closporin } \\
1.5 \% \\
\text { gel }\end{array}$ & $\begin{array}{l}\text { Top- } \\
\text { ical clo- } \\
\text { betasol } \\
0.025 \% \\
\text { gel }\end{array}$ & $\mathrm{BD}$ & $\begin{array}{l}2 \\
\text { months }\end{array}$ & $\begin{array}{l}\text { Fort- } \\
\text { nightly } \\
\text { for } 4 \\
\text { months }\end{array}$ & $\begin{array}{l}\text { Histol- } \\
\text { ogy and } \\
\text { clinical } \\
\text { (WHO) }\end{array}$ & Oral & 40 & Yes & 40 & $\begin{array}{l}\text { Topical } \\
\text { clobe- } \\
\text { tasol } \\
\text { signif- } \\
\text { icantly }\end{array}$ \\
\hline
\end{tabular}


Table 1. Summary of included studies (Continued)

\begin{tabular}{|c|c|c|c|c|c|c|c|c|c|c|c|c|}
\hline & & & & & & & & & & & & $\begin{array}{l}\text { better in } \\
\text { induc- } \\
\text { ing a } \\
\text { clinical } \\
\text { im- } \\
\text { prove- } \\
\text { ment, } \\
\text { but no } \\
\text { differ- } \\
\text { ence } \\
\text { in im- } \\
\text { proving } \\
\text { symp- } \\
\text { toms }\end{array}$ \\
\hline 8 & $\begin{array}{l}\text { Hegarty } \\
2002\end{array}$ & $\begin{array}{l}\text { Flutica- } \\
\text { s- } \\
\text { one pro- } \\
\text { pionate } \\
\text { spray } 2 \\
\text { puffs }\end{array}$ & $\begin{array}{l}\text { Be- } \\
\text { tametha- } \\
\text { sone } \\
\text { sodium } \\
\text { phos- } \\
\text { phate } \\
\text { mouth- } \\
\text { wash }\end{array}$ & $\begin{array}{l}4 \text { times } \\
\text { per day }\end{array}$ & $\begin{array}{l}14 \\
\text { weeks } \\
\text { (cross- } \\
\text { over; 2- } \\
\text { week } \\
\text { wash- } \\
\text { out) }\end{array}$ & $\begin{array}{l}\text { Week } \\
3,6,11 \text {, } \\
\text { and } 14\end{array}$ & $\begin{array}{l}\text { Histol- } \\
\text { ogy and } \\
\text { clinical }\end{array}$ & Oral & 44 & Yes & 44 & $\begin{array}{l}\text { At } \\
\text { Week } \\
6 \text { fluti- } \\
\text { casone } \\
\text { spray } \\
\text { was } \\
\text { signif- } \\
\text { icantly } \\
\text { better } \\
\text { in re- } \\
\text { ducing } \\
\text { clinical } \\
\text { signs } \\
\text { and } \\
\text { pain, } \\
\text { but no } \\
\text { differ- } \\
\text { ence in } \\
\text { VAS or } \\
\text { QoL }\end{array}$ \\
\hline \multirow[t]{2}{*}{9} & $\begin{array}{l}\text { Lin } \\
2005\end{array}$ & $\begin{array}{l}\text { Radix } \\
\text { triptery- } \\
\text { gium } \\
\text { hy- } \\
\text { poglau- } \\
\text { cum } \\
\text { tablet } \\
\text { (THT) }\end{array}$ & $\begin{array}{l}\text { Triptery- } \\
\text { gium } \\
\text { gluco- } \\
\text { sides } \\
\text { tablet } \\
\text { (TGT) }\end{array}$ & $\begin{array}{l}\text { THT - } \\
5 \text { tablets } \\
\text { TDS } \\
\text { TGT - } \\
1.0 \text { to } 1 . \\
5 \mathrm{mg} / \mathrm{kg} \\
\text { TDS } \\
\text { Taper } \\
\text { dose af- } \\
\text { ter } 2 \text { to } \\
4 \text { weeks }\end{array}$ & $\begin{array}{l}3 \\
\text { months }\end{array}$ & $\begin{array}{l}\text { Month } \\
0 \text { and } 3\end{array}$ & $\begin{array}{l}\text { Histol- } \\
\text { ogy and } \\
\text { clinical }\end{array}$ & Oral & 94 & Yes & 94 & $\begin{array}{l}\text { TGT } \\
\text { superior } \\
\text { to THT } \\
\text { in re- } \\
\text { ducing } \\
\text { clinical } \\
\text { sever- } \\
\text { ity (P = } \\
0.043)\end{array}$ \\
\hline & & & & & & & & $\begin{array}{l}\text { Subto- } \\
\text { tal }\end{array}$ & 344 & $\begin{array}{l}\text { Subto- } \\
\text { tal }\end{array}$ & 344 & \\
\hline
\end{tabular}


Table 1. Summary of included studies (Continued)

\begin{tabular}{|c|c|c|c|c|c|c|c|c|c|c|c|c|}
\hline 10 & $\begin{array}{l}\text { Choonhal } \\
2008\end{array}$ & $\begin{array}{l}\text { Aloe } \\
\text { vera gel }\end{array}$ & Placebo & $\mathrm{BD}$ & 8 weeks & $\begin{array}{l}\text { Week } 0 \text {, } \\
2,4,6 \text {, } \\
\text { and } 8\end{array}$ & $\begin{array}{l}\text { Histol- } \\
\text { ogy and } \\
\text { clinical }\end{array}$ & Oral & 54 & No & 45 & $\begin{array}{l}\text { Unable } \\
\text { to com- } \\
\text { ment }\end{array}$ \\
\hline 11 & $\begin{array}{l}\text { Eisen } \\
1990\end{array}$ & $\begin{array}{l}\mathrm{Ci}- \\
\text { closporin } \\
\text { rinse }\end{array}$ & Placebo & TDS & 8 weeks & $\begin{array}{l}\text { Week } 0 \text {, } \\
2,4,6 \text {, } \\
\text { and } 8\end{array}$ & $\begin{array}{l}\text { Histol- } \\
\text { ogy and } \\
\text { clinical }\end{array}$ & Oral & 16 & No & 8 & $\begin{array}{l}\text { Unable } \\
\text { to com- } \\
\text { ment }\end{array}$ \\
\hline 12 & $\begin{array}{l}\text { Voute } \\
1993\end{array}$ & $\begin{array}{l}\text { Fluoci- } \\
\text { nonide } \\
\text { in adhe- } \\
\text { sive base }\end{array}$ & Placebo & $\begin{array}{l}\text { At least } \\
6 \text { times } \\
\text { daily }\end{array}$ & 9 weeks & $\begin{array}{l}\text { Week } 0 \text {, } \\
3 \text {, and } \\
9 ; \text { and } \\
\text { month } \\
5 \text { to } 19\end{array}$ & $\begin{array}{l}\text { Histol- } \\
\text { ogy and } \\
\text { clinical }\end{array}$ & Oral & 40 & No & 27 & $\begin{array}{l}\text { Unable } \\
\text { to com- } \\
\text { ment }\end{array}$ \\
\hline 13 & $\begin{array}{l}\text { Malho- } \\
\text { tra } \\
2008\end{array}$ & $\begin{array}{l}\text { Be- } \\
\text { tametha- } \\
\text { sone } \\
\text { oral } \\
\text { mini- } \\
\text { pulse } \\
\text { therapy }\end{array}$ & $\begin{array}{l}\text { Topical } \\
\text { triamci- } \\
\text { nolone } \\
\text { ace- } \\
\text { tonide } \\
0.1 \% \\
\text { paste }\end{array}$ & $\begin{array}{l}\text { Be- } \\
\text { tametha- } \\
\text { sone - } \\
5 \text { mg } \\
2 \text { days/ } \\
\text { week } \\
\text { Triam- } \\
\text { ci- } \\
\text { nolone - } \\
\text { TDS } \\
\text { Both for } \\
3 \\
\text { months, } \\
\text { then ta- } \\
\text { per dose }\end{array}$ & $\begin{array}{l}6 \\
\text { months }\end{array}$ & $\begin{array}{l}\text { Week } 0 \text {, } \\
2,4,8, \\
16,20, \\
\text { and } 24\end{array}$ & $\begin{array}{l}\text { Clinical } \\
\text { only }\end{array}$ & Oral & 49 & No & 22 & $\begin{array}{l}\text { Unable } \\
\text { to com- } \\
\text { ment }\end{array}$ \\
\hline 14 & $\begin{array}{l}\text { Sardella } \\
1998\end{array}$ & $\begin{array}{l}\text { Clobe- } \\
\text { ta- } \\
\text { sol pro- } \\
\text { pionate } \\
\text { oint- } \\
\text { ment } 0 . \\
05 \%\end{array}$ & $\begin{array}{l}5 \% \\
\text { Topical } \\
\text { mesalazin } \\
\text { gel in } \\
\text { adhe- } \\
\text { sive } \\
\text { base }\end{array}$ & $\mathrm{BD}$ & 4 weeks & $\begin{array}{l}\text { Week } 0 \\
\text { and } 4\end{array}$ & $\begin{array}{l}\text { Histol- } \\
\text { ogy and } \\
\text { clinical } \\
\text { (WHO) }\end{array}$ & Oral & 25 & No & 12 & $\begin{array}{l}\text { Unable } \\
\text { to com- } \\
\text { ment }\end{array}$ \\
\hline \multirow[t]{2}{*}{15} & $\begin{array}{l}\text { Yoke } \\
2006\end{array}$ & $\begin{array}{l}\text { Triam- } \\
\text { ci- } \\
\text { nolone } \\
\text { ace- } \\
\text { tonide } \\
\text { in } \\
\text { orabase }\end{array}$ & $\begin{array}{l}\mathrm{Ci}- \\
\text { closporin } \\
\text { solution }\end{array}$ & TDS & 8 weeks & $\begin{array}{l}\text { Week } 0, \\
2, \quad 4, \\
\text { and } 8 \text {; } \\
\text { and } \\
\text { month } \\
3,6,9 \text {, } \\
\text { and } 12\end{array}$ & $\begin{array}{l}\text { Histol- } \\
\text { ogy and } \\
\text { clinical }\end{array}$ & Oral & 139 & No & 15 & $\begin{array}{l}\text { Unable } \\
\text { to com- } \\
\text { ment }\end{array}$ \\
\hline & & & & & & & & $\begin{array}{l}\text { Subto- } \\
\text { tal }\end{array}$ & 323 & $\begin{array}{l}\text { Subto- } \\
\text { tal }\end{array}$ & 129 & \\
\hline
\end{tabular}


Table 1. Summary of included studies (Continued)

\begin{tabular}{l|l|l|lll}
\hline & Total & 667 & Total & 473 & \\
\hline
\end{tabular}

*Histology - Histological features consistent with mucosal LP

Clinical - clinical features consistent with mucosal LP

WHO - Clinical features based on 1978 WHO criteria for oral precancerous lesions

Table 2. Severity Tools Used for Primary Outcomes

\begin{tabular}{|c|c|c|c|}
\hline & Study & Clinical Severity & Symptoms \\
\hline 1 & Passeron 2007 & Surface area ordinal scale 1 to 4 & Pain (basal and during feeding, visual scale 0 to 4 ) \\
\hline 2 & Swift 2005 & $\begin{array}{l}\text { Clinical score (weighted sums of ulceration } \mathrm{mm}^{2} \text {, } \\
\text { erythema } \mathrm{mm}^{2} \text {, reticulation } \mathrm{mm}^{2} \text { ) }\end{array}$ & VAS 0 to 100 \\
\hline 3 & Volz 2008 & $\begin{array}{l}\text { Erosive surface area ordinal scale of } 1 \text { to } 4(<5 \% \\
=1,5 \% \text { to } 15 \%=2,>15 \% \text { to } 25 \%=3,>25 \%= \\
4) \\
\text { Investigator Global Assessment on a } 5 \text {-point scale } \\
\text { was determined at day } 30 \text { by qualifying the overall } \\
\text { status of the oral mucosa in comparison with base- } \\
\text { line }\end{array}$ & $\begin{array}{l}\text { VAS } 0 \text { to } 10 \text { (continuous and food-triggered pain) } \\
\text { NB a composite score (made of erosive surface area } \\
\text { and VAS) was reported }\end{array}$ \\
\hline 4 & Campisi 2004 & Clinical score 0 to 5 (Thongprasom 1992) & VAS 0 to 100 \\
\hline 5 & Carbone 2009 & Clinical score 0 to 5 (Thongprasom 1992) & VAS 0 to 100 \\
\hline 6 & Radfar 2008 & Mean lesion size & VAS 0 to 10 \\
\hline 7 & Conrotto 2006 & Clinical score 0 to 5 (Thongprasom 1992) & VAS 0 to 10 \\
\hline 8 & Hegarty 2002 & $\begin{array}{l}\text { Clinical score } 0 \text { to } 5 \text { (Thongprasom 1992) } \\
\text { Mean surface area }\end{array}$ & $\begin{array}{l}\text { 1. VAS } 0 \text { to } 100 \\
\text { 2. McGill pain score }\end{array}$ \\
\hline 9 & Lin 2005 & $\begin{array}{l}\text { Clinical severity } \\
\text { Participants divided into Grade I (erosive and ul- } \\
\text { cerative lesions) or Grade II (erosive lesions only) } \\
\text { Response reported, subdivided into } 3 \text { categories } \\
\text { (cured completely, effective, ineffective) }\end{array}$ & None \\
\hline 10 & Choonhakarn 2008 & Clinical score 0 to 5 (Thongprasom 1992) & VAS 0 to 10 \\
\hline 11 & Eisen 1990 & Clinical score (0 to 3$)$ & Symptom score (0 to 3$)$ \\
\hline 12 & Voute 1993 & $\begin{array}{l}\text { Clinical severity measured by comparing clinical } \\
\text { photographs. Only response reported, subdivided } \\
\text { into } 5 \text { categories }\end{array}$ & VAS (scale not stated) \\
\hline
\end{tabular}

Interventions for erosive lichen planus affecting mucosal sites (Review)

Copyright $\odot 2012$ The Cochrane Collaboration. Published by John Wiley \& Sons, Ltd. 
Table 2. Severity Tools Used for Primary Outcomes

13 Malhotra 2008

Clinical score (semiquantitative system 0 to 12 None

based on site, area, and presence of erosions)

\begin{tabular}{llll}
\hline 14 & Sardella 1998 & None & VAS 0 to 10 \\
\hline 15 & Yoke 2006 & Clinical score 0 to 5 (Thongprasom 1992) & VAS 0 to 100 \\
\hline
\end{tabular}

Table 3. Side-effects

\begin{tabular}{|c|c|c|c|c|}
\hline & Study & Intervention 1 & Intervention 2 & Side-effects \\
\hline 1 & Passeron 2007 & $1 \%$ pimecrolimus cream & Placebo & $\begin{array}{l}\text { Pimecrolimus well-tolerated, } \\
\text { transient burning (2) during 1st } \\
2 \text { weeks }\end{array}$ \\
\hline 2 & Swift 2005 & $1 \%$ pimecrolimus cream & Placebo & $\begin{array}{l}\text { Pimecrolimus: slight burning tip } \\
\text { of tongue after applying } 1 \% \\
\text { pimecrolimus on gingiva lesions. } \\
\text { Resolved within minutes }\end{array}$ \\
\hline 3 & Volz 2008 & $1 \%$ pimecrolimus cream & Placebo & $\begin{array}{l}\text { Pimecrolimus: burning sensation } \\
\text { (4) and mucosal paraesthesia (1) } \\
\text { Placebo: burning sensation (1) } \\
\text { and mucosal paraesthesia (1) }\end{array}$ \\
\hline 4 & Campisi 2004 & $\begin{array}{l}\text { Clobetasol-17-propionate lipid- } \\
\text { loaded micro-spheres } 0.025 \%\end{array}$ & $\begin{array}{l}\text { Conventional lipophilic oint- } \\
\text { ment in hydrophilic phase } 0 . \\
025 \%\end{array}$ & $\begin{array}{l}\text { Oral candidiasis ( } 1 \text { in lipid- } \\
\text { loaded microspheres group, } 2 \text { in } \\
\text { conventional ointment group) }\end{array}$ \\
\hline 5 & Carbone 2009 & $\begin{array}{l}\text { Topical clobetasol propionate } 0 \text {. } \\
025 \%\end{array}$ & $\begin{array}{l}\text { Topical clobetasol propionate } 0 \text {. } \\
05 \%\end{array}$ & No side-effects \\
\hline 6 & Radfar 2008 & $\begin{array}{l}\text { Topical tacrolimus } 0.1 \% \text { oint- } \\
\text { ment }\end{array}$ & $\begin{array}{l}\text { Topical clobetasol } 0.05 \% \text { oint- } \\
\text { ment }\end{array}$ & $\begin{array}{l}\text { Burning sensation with topical } \\
\text { tacrolimus }\end{array}$ \\
\hline 7 & Conrotto 2006 & Topical ciclosporin $1.5 \%$ gel & Topical clobetasol $0.025 \%$ gel & $\begin{array}{l}\text { Ciclosporin: skin rashes (2), } \\
\text { parotid swelling (1), and dyspep- } \\
\text { sia (3) } \\
\text { Clobetasol: dyspepsia (1) }\end{array}$ \\
\hline 8 & Hegarty 2002 & $\begin{array}{l}\text { Fluticasone propionate spray, } 2 \\
\text { puffs }\end{array}$ & $\begin{array}{l}\text { Betamethasone sodium phos- } \\
\text { phate mouthwash }\end{array}$ & $\begin{array}{l}\text { Nausea (4); swollen mouth (1) } \\
\text {; bad taste and smell (6); dif- } \\
\text { ficulty in spray application (7); } \\
\text { dry mouth (2); sore throat (1); } \\
\text { red, painful tongue (1); and pseu- } \\
\text { domembranous candidiasis (1) }\end{array}$ \\
\hline
\end{tabular}


Table 3. Side-effects

$9 \quad$ Lin 2005

Radix tripterygium hypoglau- Tripterygium glucosides tablet TGT-menstrual disturbance (6) cum tablet (THT)

(TGT) and leucopenia (1)

\begin{tabular}{|c|c|c|c|c|}
\hline 10 & Choonhakarn 2008 & Aloe vera gel & Placebo & $\begin{array}{l}\text { No serious side-effects. } 2 \text { receiv- } \\
\text { ing aloe vera gel reported stinging } \\
\text { and mild itching at lesions within } \\
\text { 1st week, but symptoms sponta- } \\
\text { neously disappeared with contin- } \\
\text { ued use }\end{array}$ \\
\hline 11 & Eisen 1990 & Ciclosporin rinse & Placebo & $\begin{array}{l}\text { No adverse side-effects. Transient } \\
\text { burning sensation of mucosal sur- } \\
\text { faces during swishing of medica- } \\
\text { tion reported in all participants }\end{array}$ \\
\hline 12 & Voute 1993 & Fluocinonide in adhesive base & Placebo & $\begin{array}{l}\text { No side-effects during study and } \\
\text { follow-up period }\end{array}$ \\
\hline 13 & Malhotra 2008 & $\begin{array}{l}\text { Betamethasone oral mini-pulse } \\
\text { therapy }\end{array}$ & $\begin{array}{l}\text { Topical triamcinolone acetonide } \\
0.1 \% \text { paste }\end{array}$ & $\begin{array}{l}\text { Betamethasone: oedema over face } \\
\text { (transient) ( } 7) \text {, oedema over } \\
\text { hands and feet (4), epigastric dis- } \\
\text { comfort ( } 7 \text { ), weakness/fatigue (5) } \\
\text {, loose stools (1), headache (1), } \\
\text { diabetes mellitus (1), weight gain } \\
\text { (1), and dry mouth (1) } \\
\text { Triamcinolone: epigastric dis- } \\
\text { comfort (1) and candidiasis (5) }\end{array}$ \\
\hline 14 & Sardella 1998 & $\begin{array}{l}\text { Clobetasol propionate ointment } \\
0.05 \%\end{array}$ & $\begin{array}{l}5 \% \text { Topical mesalazine gel in ad- } \\
\text { hesive base }\end{array}$ & No side-effects \\
\hline 15 & Yoke 2006 & $\begin{array}{l}\text { Triamcinolone acetonide in } \\
\text { orabase }\end{array}$ & Ciclosporin solution & $\begin{array}{l}\text { No significant } \\
\text { adverse events. Transient burning } \\
\text { sensation upon initial application } \\
\text { with both treatments }\end{array}$ \\
\hline
\end{tabular}




\section{A P P E N D I C E S}

\section{Appendix I. CENTRAL (Cochrane Library) search strategy}

\#1((eros* or vulva* or oral or ulcerated or mucos*) and (lichen and planus))

\#2MeSH descriptor Lichen Planus explode all trees

\#3(lichen planus)

\#4(\#1 OR \#2 OR \#3)

\section{Appendix 2. MEDLINE (OVID) search strategy}

1. randomized controlled trial.pt.

2. controlled clinical trial.pt.

3. randomized.ab.

4. placebo.ab.

5. clinical trials as topic.sh.

6. randomly.ab.

7. trial.ti.

8. 1 or 2 or 3 or 4 or 5 or 6 or 7

9. (animals not (human and animals)).sh.

10. 8 not 9

11. erosive lichen planus.mp.

12. Lichen planus.mp. or exp Lichen Planus/

13. vulval lichen planus.mp.

14. vulvar lichen planus.mp.

15. oral erosive lichen planus.mp.

16. ulcerated lichen planus.mp.

17. mucosal lichen planus.mp.

18. 11 or 16 or 13 or 17 or 12 or 15 or 14

19. 18 and 10

\section{Appendix 3. EMBASE (OVID) search strategy}

1. random\$.mp.

2. factorial\$.mp.

3. (crossover $\$$ or cross-over $\$$ ).mp.

4. placebo\$.mp. or PLACEBO/

5. (doubl\$ adj blind\$).mp. [mp=title, abstract, subject headings, heading word, drug trade name, original title, device manufacturer, drug manufacturer name]

6. (singl\$ adj blind\$).mp. [mp=title, abstract, subject headings, heading word, drug trade name, original title, device manufacturer, drug manufacturer name]

7. (assign\$ or allocat\$).mp.

8. volunteer\$.mp. or VOLUNTEER/

9. Crossover Procedure/

10. Double Blind Procedure/

11. Randomized Controlled Trial/

12. Single Blind Procedure/

13. 1 or 2 or 3 or 4 or 5 or 6 or 7 or 8 or 9 or 10 or 11 or 12

14. erosive lichen planus.mp.

15. Lichen planus.mp. or exp Lichen Planus/

16. vulval lichen planus.mp.

17. vulvar lichen planus.mp. 
18. oral erosive lichen planus.mp.

19. ulcerated lichen planus.mp.

20. mucosal lichen planus.mp.

21. 14 or 19 or 16 or 20 or 15 or 18 or 17

22. 21 and 13

\section{Appendix 4. LILACS search strategy}

((Pt RANDOMIZED CONTROLLED TRIAL OR Pt CONTROLLED CLINICAL TRIAL OR Mh RANDOMIZED CONTROLLED TRIALS OR Mh RANDOM ALLOCATION OR Mh DOUBLE-BLIND METHOD OR Mh SINGLE-BLIND METHOD OR Pt MULTICENTER STUDY) OR ((tw ensaio or tw ensayo or tw trial) and (tw azar or tw acaso or tw placebo or tw control\$ or tw aleat\$ or tw random\$ or (tw duplo and tw cego) or (tw doble and tw ciego) or (tw double and tw blind)) and tw clinic\$)) AND NOT ((CT ANIMALS OR MH ANIMALS OR CT RABBITS OR CT MICE OR MH RATS OR MH PRIMATES OR MH DOGS OR MH RABBITS OR MH SWINE) AND NOT (CT HUMAN AND CT ANIMALS)) [Words] and (lichen and planus) or (liquen and plano) [Words]

\section{WHAT'S NEW}

Last assessed as up-to-date: 15 June 2009.

\begin{tabular}{|c|c|c|}
\hline Date & Event & Description \\
\hline 16 May 2012 & Amended & $\begin{array}{l}\text { Reference has been made to the updated Cochrane review on "Interventions for Oral Lichen Planus" } \\
\text { (Thongprasom 2011) } \\
\text { Minor amendments have been made to the Abstract and the Plain Language Summary }\end{array}$ \\
\hline
\end{tabular}

\section{CONTRIBUTIONSOFAUTHORS}

Conceiving the review: S Cheng and R Murphy

Designing the review: S Cheng, G Kirtschig, S Cooper, M Thornhill, J Leonardi-Bee, and R Murphy

Co-ordinating the review: S Cheng and R Murphy

Collecting data for the review: S Cheng and R Murphy

Designing search strategies: S Cheng and R Murphy

Undertaking searches: S Cheng and R Murphy

Screening search results: S Cheng and R Murphy

Organising the retrieval of papers: S Cheng and R Murphy

Screening retrieved papers against eligibility criteria: S Cheng and R Murphy

Appraising the quality of papers: S Cheng and R Murphy

Extracting data from papers: S Cheng and R Murphy

Writing to authors of papers for additional information: S Cheng and R Murphy

Providing additional data about papers: S Cheng and R Murphy

Obtaining and screening data on unpublished studies: S Cheng and R Murphy

Copyright @ 2012 The Cochrane Collaboration. Published by John Wiley \& Sons, Ltd. 
Data management for the review: S Cheng and R Murphy

Entering data into RevMan: S Cheng and R Murphy

Analysing the data: J Leonardi-Bee

Interpreting the data: S Cheng, R Murphy, and J Leonardi-Bee

Providing a methodological perspective: J Leonardi-Bee

Providing a clinical perspective: S Cheng and R Murphy

Providing a policy perspective: R Murphy

\section{DECLARATIONSOF INTEREST}

None known.

\section{SOURCES OF SUPPORT}

\section{Internal sources}

- Nottingham University Hospitals Trust, UK.

\section{External sources}

- No sources of support supplied

\section{DIFFERENCES BETWEEN PROTOCOLANDREVIEW}

There were minor updates to the background section.

We did not collect data on adverse events from interventions for erosive lichen planus by running separate searches looking specifically for adverse effects of treatments used. This was an over-ambitious goal and an under-estimation of the extensive search required to fulfil this.

We added in a secondary outcome (j) reduction in target/mean lesion size (for oral lesions), which was measured by two studies.

\section{INDEX TERMS}

\section{Medical Subject Headings (MeSH)}

Adrenal Cortex Hormones [adverse effects; therapeutic use]; Anti-Inflammatory Agents, Non-Steroidal [adverse effects; therapeutic use]; Autoimmune Diseases [*drug therapy]; Chronic Disease; Genital Diseases, Female [*drug therapy]; Genital Diseases, Male [*drug therapy]; Immunosuppressive Agents [adverse effects; therapeutic use]; Lichen Planus [ ${ }^{*}$ drug therapy]; Lichen Planus, Oral [*drug therapy]; Mucous Membrane; Pain Measurement; Randomized Controlled Trials as Topic 


\section{MeSH check words}

Female; Humans; Male

Copyright $\odot 2012$ The Cochrane Collaboration. Published by John Wiley \& Sons, Ltd. 